Florida International University FIU Digital Commons

FIU Electronic Theses and Dissertations

University Graduate School

2-23-2004

\title{
Palm fuel dynamics in fire-sustained pine forests in the Florida Keys
}

Hillary Clare Cooley

Florida International University

DOI: $10.25148 /$ etd.FI14061503

Follow this and additional works at: https://digitalcommons.fiu.edu/etd

Part of the Environmental Sciences Commons

\section{Recommended Citation}

Cooley, Hillary Clare, "Palm fuel dynamics in fire-sustained pine forests in the Florida Keys" (2004). FIU Electronic Theses and Dissertations. 2525.

https://digitalcommons.fiu.edu/etd/2525

This work is brought to you for free and open access by the University Graduate School at FIU Digital Commons. It has been accepted for inclusion in FIU Electronic Theses and Dissertations by an authorized administrator of FIU Digital Commons. For more information, please contact dcc@fiu.edu. 
FLORIDA INTERNATIONAL UNIVERSITY

Miami, Florida

PALM FUEL DYNAMICS IN FIRE-SUSTAINED PINE FORESTS IN THE FLORIDA KEYS

A thesis submitted in partial fulfillment of the

requirements for the degree of

MASTER OF SCIENCE

in

ENVIRONMENTAL STUDIES

by

Hillary Clare Cooley

2004 
To: Dean R. Bruce Dunlap

College of Arts and Sciences

This thesis, written by Hillary Clare Cooley, and entitled Palm Fuel Dynamics in FireSustained Pine Forests in the Florida Keys, having been approved in respect to style and intellectual content, is referred to you for judgment.

We have read this thesis and recommend that it be approved.

Alice L. Clarke

Bradley C. Bennett

James R. Snyder

Michael S. Ross, Major Professor

Date of Defense: February 23, 2004

The thesis of Hillary Clare Cooley is approved.

Dean R. Bruce Dunlap College of Arts and Sciences

Dean Douglas Wartzok University Graduate School

Florida International University, 2004 


\section{DEDICATION}

I dedicate this thesis to my mother for her love and patience not only during completion of this degree, but throughout my entire life. 


\section{ACKNOWLEDGMENTS}

I wish to thank the members of my committee for their guidance and support. Special thanks go to my major professor, Dr. Michael Ross for his support and patience and for giving me the opportunity to work with him.

With sincere gratitude I thank the Forrest C. Lattner Foundation for funding the 2001 and 2002 summer internship program with The Nature Conservancy of the Florida Keys and the Department of Environmental Studies, Florida International University, which allowed me conduct my fieldwork.

I am indebted to the people who braved heat and mosquitoes to help me in the field: Karina Becerra, Susan Lauman, David Jones and Mike Ross. I thank Chris Bergh, and Chris Borg, for input of ideas.

Thanks to Diane Riggs for many things including encouragement, and housing. I also thank my lab mates: Dave Reed, David Jones, Pablo Ruiz, and Jay Sah for statistical help, feedback and encouragement. Special thanks to David Jones for editorial comments. Thanks to Suzanne Koptur for fire and palm seedling pictures used in defense talk. I also thank my friends and family for their love and encouragement.

Data collected under United States Department of the Interior U.S. Fish and Wildlife Service Special Use Permit Number 41580-02-302. 


\section{ABSTRACT OF THE THESIS \\ PALM FUEL DYNAMICS IN FIRE-SUSTAINED PINE \\ FORESTS IN THE FLORIDA KEYS \\ by \\ Hillary Clare Cooley \\ Florida International University, 2004 \\ Miami, Florida \\ Professor Michael S. Ross, Major Professor}

In this study, the relationships between the time since last fire and the contributions of two palm species (Silverpalm, Coccothrinax argentata and Key Thatch Palm, Thrinax morrisii) to the burnable fuel load in the lower Florida Keys were examined. The population size distributions, effects of fire and plant size on mortality, annual growth rate, minimum reproductive size, and leaf moisture content of the palms were also determined.

Regression models were developed to estimate the live and attached dead burnable biomass for both palm species. Equations with crown area and number of leaves as independent variables best predicted the amount of burnable biomass. Fuel accumulation was then modeled to determine the time until different biomass components begin to stabilize after fire. Live palm biomass continued to increase for approximately 2-5 years after fire, while dead attached biomass continued to increase for up to 15-20 years. In the burned sites a greater percent of mortality was observed in the larger palms. 


\section{TABLE OF CONTENTS}

I. INTRODUCTION.

Objectives.

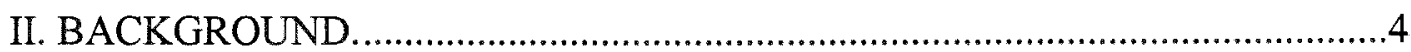

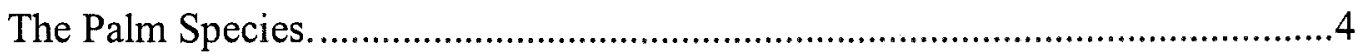

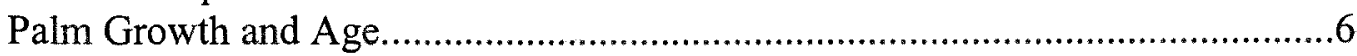

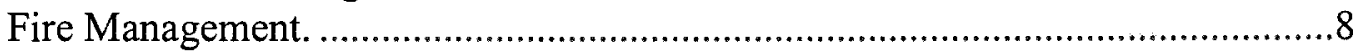

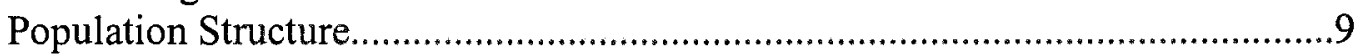

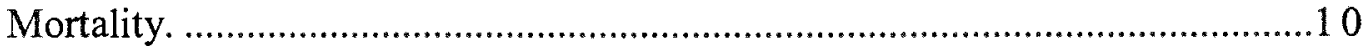

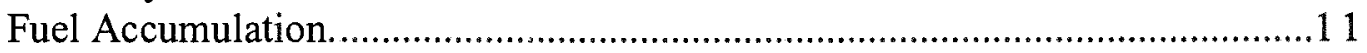

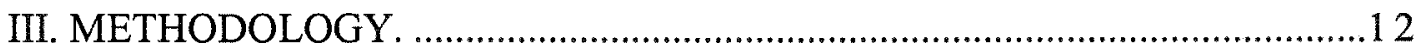

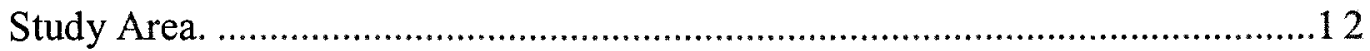

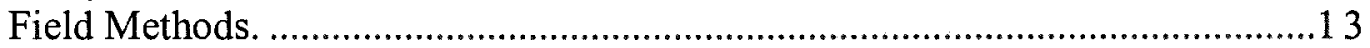

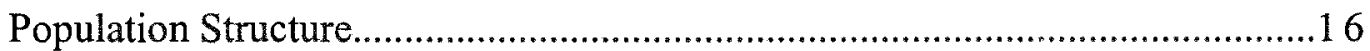

Mortality, Growth and Reproduction ............................................................18

Aboveground Burnable Biomass Estimates....................................................19

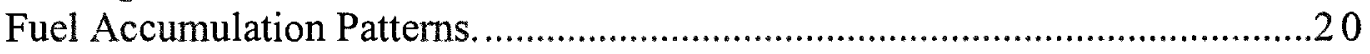

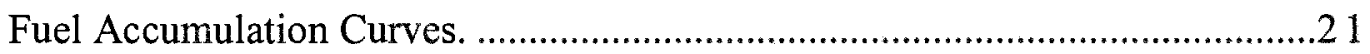

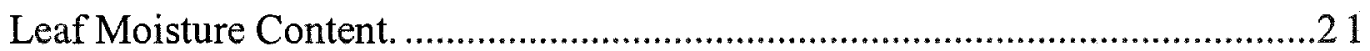

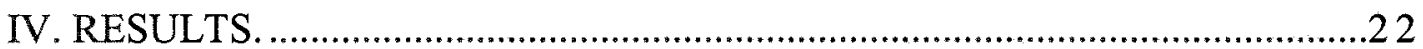

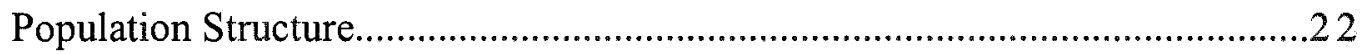

Population Density and Time Since Last Fire. .................................................24

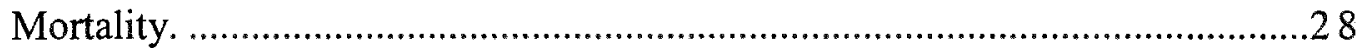

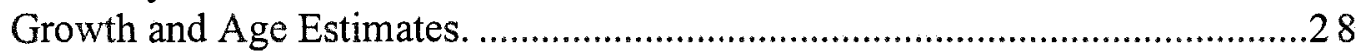

Reproduction Status versus Size-Class............................................................ 31

Aboveground Burnable Biomass Estimates...................................................32

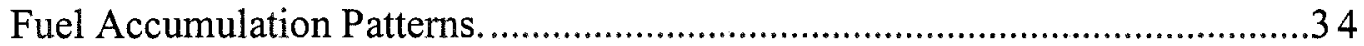

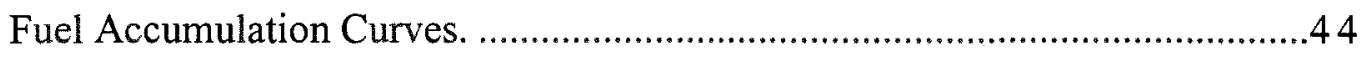

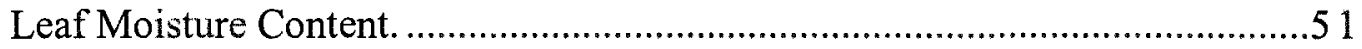

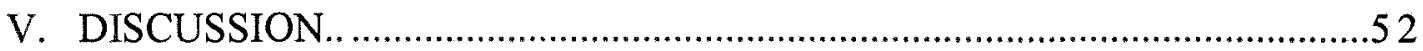

Population Size-Structure and Biomass Accumulation...................................52

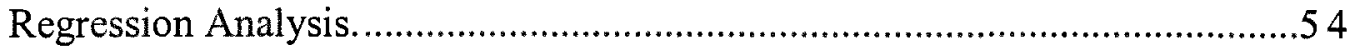

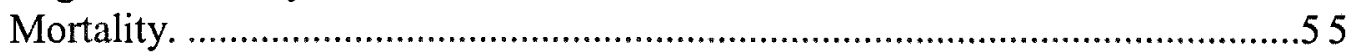

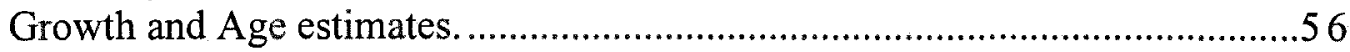

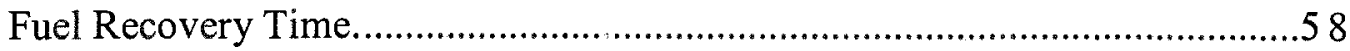

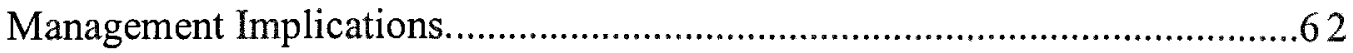


APPENDICES. . 


\section{LIST OF TABLES}

TABLE

PAGE

1. Site names, islands, burn dates, sampling dates and methods. ....................... 15

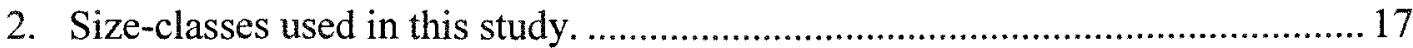

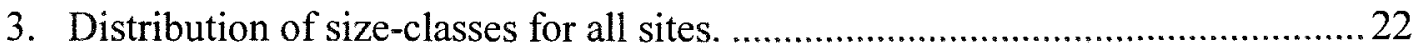

4. Palm mortality of burned versus unburned sites..............................................29

5. Growth rate of palms in Iris-number and percent............................................ 31

6. Percent of reproductive individuals by size-class............................................32

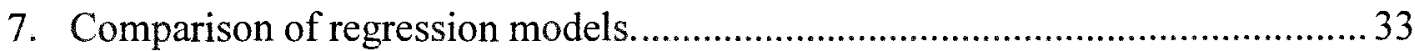

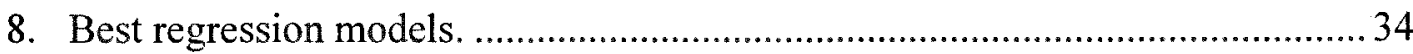

9. Individual level fuel loading for all 17 sites. ................................................... 45

10. Palm community level fuel loading for all 17 sites. ....................................... 48

11. Parameter estimates for fuel accumulation. ........................................................51

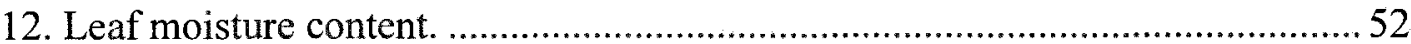




\section{LIST OF FIGURES}

FIGURE

PAGE

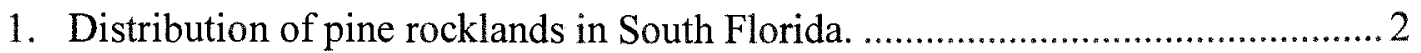

2. Distribution of Coccothrinax argentata and Thrinax morrisii.........................6 6

3. Map of the study area with plot locations........................................................ 14

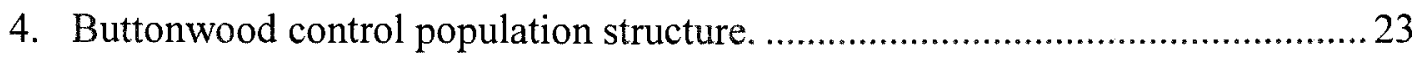

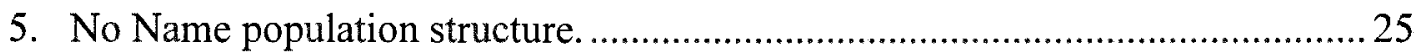

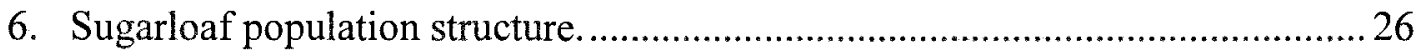

7. Population density ranked in order of time since last fire ................................2

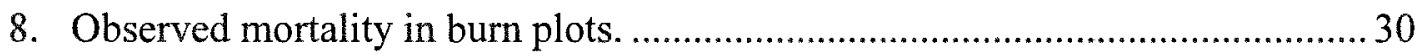

9. Average grams/individual contributed by each size-class of $C$. argentata ......36

10. Average grams/individual contributed by each size-class of $T$. morrisii........... 37

11. Average $\mathrm{kg} / \mathrm{ha}$ contributed by each size-class of $C$. argentata ........................ 38

12. Average $\mathrm{kg} / \mathrm{ha}$ contributed by each size-class of $T$. morrisii........................... 39

13. C. argentata total $\mathrm{kg} /$ ha ranked in order of time since last fire..........................4 41

14. T. morrisii total $\mathrm{kg} / \mathrm{ha}$ ranked in order of time since last fire ......................... 42

15. Total litter $\mathrm{kg} / \mathrm{ha}$ for both species ranked in order of time since last fire........... 43

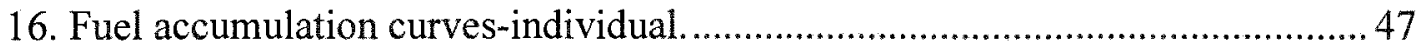

17. Fuel accumulation curves-palm community level. ........................................49 


\section{LIST OF ACRONYMS}

NKDR- National Key Deer Refuge

FIU- Florida International University

USGS-United States Geological Survey

USFWS-United States Fish and Wildlife Service

CL-Crown length

CW-Crown width

CA-Crown area

DBH-Diameter at breast height 


\section{INTRODUCTION}

The pine rocklands of southern Florida (Figure 1) are a globally endangered ecosystem (Noss, La-Roe III and Scott 1995). They are characterized by having a limestone substrate, a canopy of Slash Pine (Pinus elliottii Engelm.), and an understory containing West Indian tropical species, endemic herbs and several palm species. Fire is a natural and essential component of the pine rockland ecosystem. Without fire, pines and the characteristic understory are replaced by tropical hardwood species (Garren 1943, Alexander and Dickerson 1972, Snyder 1986, Snyder et al.1990). In the pine rocklands of Everglades National Park, herbs and palms recover their dry mass rapidly after fire, reaching burnable levels within one year of a prescribed burn (Snyder 1986).

In Florida Keys pine forests, palms such as Coccothrinax argentata (Jacq.) L.H. Bailey (Silver Palm), Thrinax morrisii H. Wendl. (Key Thatch Palm), and Serenoa repens (Bartr.) Small (Saw Palmetto) comprise an especially important structural feature in the subcanopy (Snyder et al. 1990). Palms, in particular, are fire tolerant due to their lack of vulnerable meristematic tissue; they lack a vascular cambium, vascular bundles are distributed throughout the stem, and apical buds are often well insulated by leaf bases (McPherson and Williams 1998). In this paper I describe several aspects of the role of Coccothrinax argentata and Thrinax morrisii in the fire regime of the Florida Keys pine rocklands.

Prior to human settlement of the lower Florida Keys, lightning-ignited fires maintained endemic pine rockland species. Due to fire suppression and construction of roads, canals and homes, which all act as fire breaks, fragmentation of the pine forest has probably reduced the area burned by natural lightning-started fires. With reduced fire 


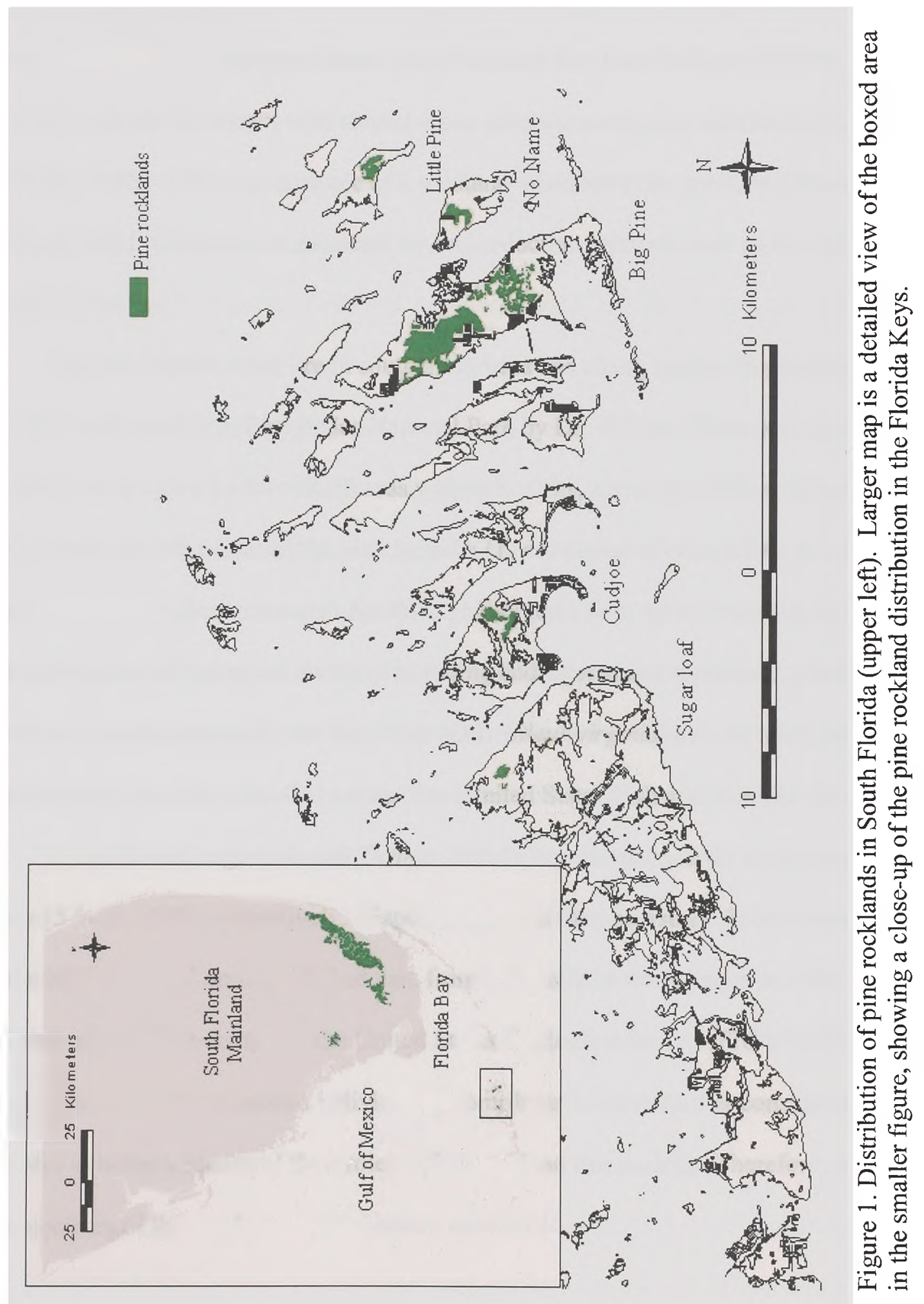


frequency and extent, fuels build up and increase the chance of catastrophic fire, which can damage nearby homes and also may kill overstory pines. Today, it is estimated that on Big Pine Key, the largest island in the National Key Deer Refuge (NKDR), more than 500 homes are in contact with natural areas, predominantly pine rocklands (Bergh and Wisby 1996). This is an example of a wildland urban interface problem (Winter and Fried 2000), which can be mediated by fuel reduction methods such as the use of prescribed fire.

The use of prescribed fire in southern Florida has a long history, beginning in the 1950s with studies in Everglades National Park by Dr. William Robertson (Robertson 1953). A fire plan for the NKDR was written in 1971, revised in 1983 and again in 2000. Currently the objectives of the plan include: (1) protection of human life, property, and other resources from unwanted fire through fuel reduction, and (2) restoration and maintenance of biological diversity including endangered and threatened plant and animal species, especially the Key Deer (Odocoileus virginianum clavium), through prescribed fire and controlled natural fire (United States Fish and Wildlife Service 2000).

Coccothrinax argentata and Thrinax morrisii are common in the study area and make up $15 \%$ and $27 \%$, respectively, of species cover in the understory shrub community in the NKDR, based on unpublished data from a fire effects study begun in 1998 by Florida International University and the United States Geological Survey (FIU/USGS). The amount of fuel these species individually contribute is worth further consideration in order to better understand their role in pine rockland fire ecology. Therefore, the objectives of this study were to: 
(1) Describe the abundance and population structure of Coccothrinax argentata and Thrinax morrisii in NKDR and how they vary with respect to time since last fire.

(2) Assess the effects of fire and plant size on the survival/mortality of C. argentata and T. morrisii.

(3) Estimate the annual growth rate of $C$. argentata and T. morrisii, and use this rate to estimate stand age.

(4) Determine the minimum size for reproductive maturity of C. argentata and $T$. morrisii.

(5) Estimate the length of time typically elapsed following fire before $C$. argentata and T. morrisii live, attached dead, and litter fuels return to pre-fire levels.

This study emphasizes the last objective. However the results from all the above objectives will provide a better understanding of the unique contribution that palm fuel plays in this fire-adapted ecosystem. This information combined with the response of hardwood tree species, endemic herbs, and wildlife to fire will help to provide a better understanding of the frequency and effectiveness of prescribed burning in the NKDR. This scientific information along with the residential concerns, recreational needs and conservation goals of this urban interface area all need to be integrated in fire management planning.

\section{BACKGROUND}

\section{The Palm Species}

Coccothrinax argentata and Thrinax morrisii (Arecaceae) co-occur in the lower Florida Keys. The genus Coccothrinax contains fourteen species distributed throughout 
the Greater Antilles (especially Cuba) and the Lesser Antilles and other Caribbean Islands, including Trinidad and Tobago (Henderson et al. 1995). It is also found in Florida and the Yucatán Peninsula of Mexico (Henderson et al. 1995). C. argentata is widely distributed in the Caribbean, the east coast of Mexico, Cuba, the Florida Keys and the southern tip of the Florida peninsula (Figure 2). C. argentata usually occurs near the sea in open areas or partially closed woods, on sandy soils overlying limestone, at low elevations (Henderson et al. 1995, Zona 1997, Tomlinson 2001). In some Caribbean countries, the trunks of $C$. argentata are used in construction and the leaves are used for thatching. It is often planted as an ornamental (Henderson et al. 1995). C. argentata is listed as a threatened species by the state of Florida (Coile 1998).

Thrinax contains seven species, distributed throughout the northwestern Caribbean, usually in coastal regions (Henderson et al. 1995). Thrinax morrisii is found in the Florida Keys, Bahamas, Cuba, Navassa Island (located between Haiti and Jamaica), Puerto Rico, and the western Lesser Antilles (Figure 2). T. morrisii grows in dry, deciduous woodlands or open coastal regions, often directly on limestone, usually at low elevations (Henderson et al. 1995). In the Florida Keys, T. morrisii fruits are consumed by Key deer (Klimstra et al. 1974, Klimstra and Dooley 1990). T. morrisii is used for thatch, timber, and landscaping throughout the Caribbean (Olmsted and Alvarez-Buylla 1995). T. morrisii is listed as an endangered species by the state of Florida (Coile 1998). Nauman (1990) presented evidence of hybridization between T. morrisii and C. argentata on Big Pine Key and No Name Key. 


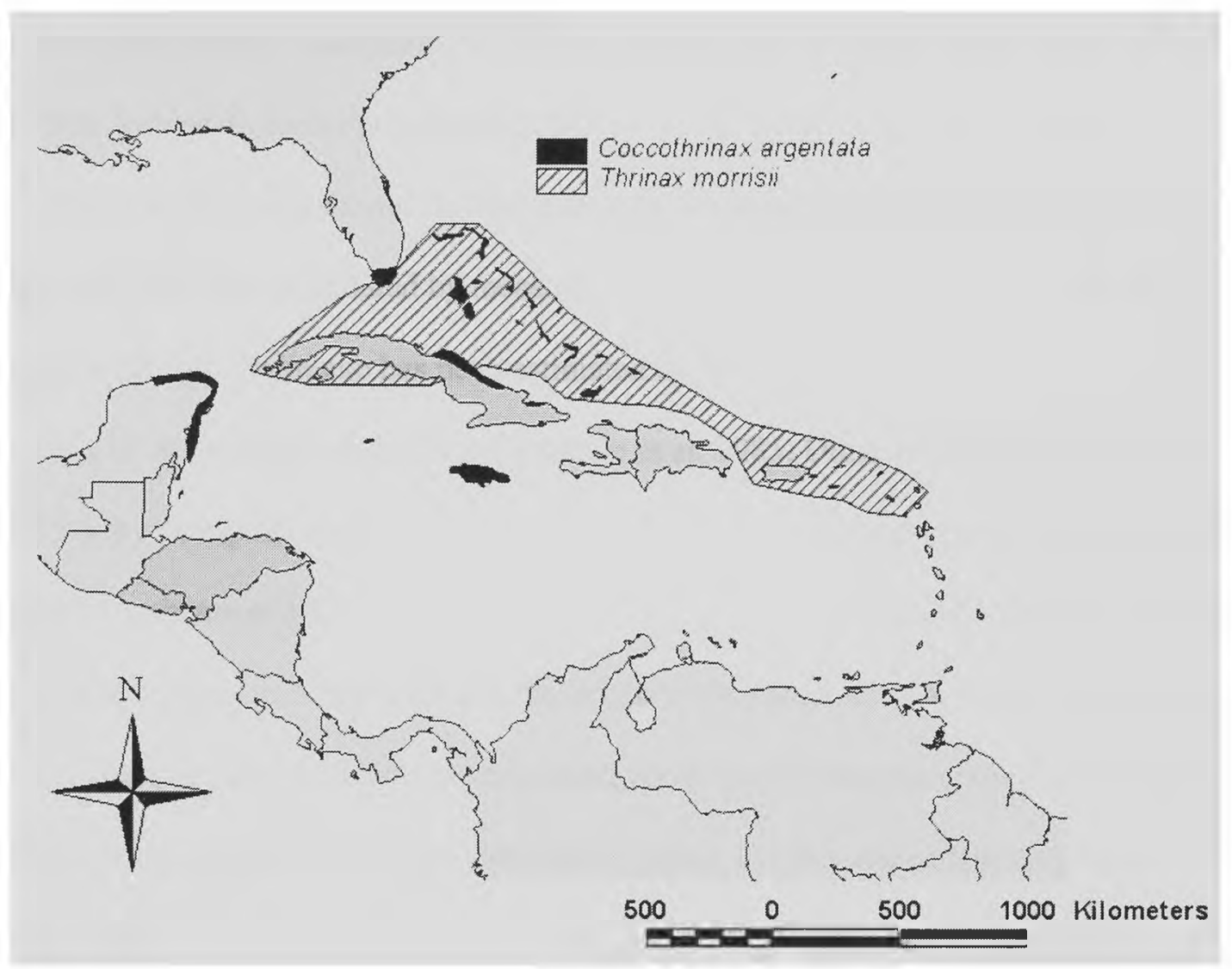

Figure 2. Distribution of Coccothrinax argentata and Thrinax morrisii (Henderson et al. 1995).

\section{Palm Growth and Age}

Palm growth is typical of monocotyledons in that secondary thickening is lacking (Tomlinson 2001). The embryo of a palm is initially narrow; in the early growth stages, the stem widens with each leaf produced, entirely by primary growth and with minimum increase in internode length. This period is often referred to as the establishment phase (Tomlinson 2001). According to McPherson and Williams (1996), the establishment phase for Sabal palmetto (Walt.) Lodd. ex Schultes (Cabbage Palm) may be from 30 to 60 years. The diameter of the mature stem is determined by the length of the 
establishment phase. Essentially, in order to become tall, the palm delays height growth and first widens its stem (Tomlinson 2001).

The age of a palm cannot be determined from annual growth rings. However, rates of growth have been estimated by measuring the rate of leaf production, which can change with age. Palm age has been estimated by counting the number of leaf scars and dividing by annual leaf production (Sarukhán et al. 1985, Olmsted and Alvarez-Buylla 1995) or by extrapolating based on the relationship between stem-growth rates and stem length (Abrahamson 1995). The accuracy of these methods is limited by factors such as variable growth rates in the wild and the length of the establishment phase (Tomlinson 2001). There are also problems extrapolating these ages to determine the general age of the palm community, because growth rates of palms are very dependent on genetic factors and the local growing conditions. Zona and Maidman (2000) found this to be true based on growth rates of Coccothrinax argentata and Thrinax morrisii individuals at Fairchild Tropical Garden in Miami, Florida. These authors also warn that rates need to be taken over a lifetime because palms may grow quickly as juveniles, and slowly as reproductive adults. Nevertheless, Zona and Maidman (2000) reported the mean growth of $C$. argentata to be $12 \mathrm{~cm} / \mathrm{yr}$ and the mean growth rate of $T$. morrisii to be $3 \mathrm{~cm} / \mathrm{yr}$ under garden conditions. These rates may not be typical of palms in the wild, including on Big Pine Key. According to Tomlinson (2001), an upper limit estimate for the age of palms in the wild is probably about 200 years. 


\section{Fire Management}

Fire is a natural and historic factor that shapes the landscape of pine rocklands in south Florida (Snyder et al.1990). Fires are ignited by lightning or by humans in either controlled prescription burns, by accident, or by arson. Land managers can use fire as a "tool" to manipulate and to change the landscape. Fires conducted under prescription have many important ecological objectives. Some of the most important objectives pertaining to vegetation are to control invasive non-native species, promote the growth and reproduction of native fire dependent or adapted species, and to reduce the amount of burnable fuel present (Snyder 1986, Whelan 1995, Bond and van Wilgen 1996).

The susceptibility of both plant communities and built structures to wildfire depends on the physiological and morphological adaptations of plants, fuel type, fuel amount, stand density, season of burning and the weather conditions at the time of the fire (Snyder 1986, Oba 1990, Bessie and Johnson 1995, Bond and van Wilgen 1996, van Wilgen et al. 2001). Plants have properties that make them more or less susceptible to fire. The most important of these is the production or retention of dead material (Bond and van Wilgen 1996). The moisture content of dead plant material is usually lower than that of live plant material, and it is the dead fuel that initially carries the fire (Bond and van Wilgen 1996). The combustion of dead fuel drives the moisture out of the live fuel. Typically, live plant parts have a moisture content between $50-250 \%$ of dry mass (Bond and van Wilgen 1996). Live leaves with lower moisture content burn more readily than more hydrated leaves because less water needs to be driven off prior to ignition. Therefore, the accumulation of dead plant material in an ecosystem is an important determinant of its 
vulnerability to wildfires, and should be considered in assessments of the fuel properties of vegetation communities, or in predictions of fire severity.

For example, van Wilgen (1982) found that frequent burning in the "fynbos" communities of South Africa kept biomass levels low. Suppression of fire for longer then 30 years resulted in a decline in live biomass and an increase in dead biomass, much of which had fallen to the ground as litter. Fires in such senescent stands were usually more severe.

\section{Population Structure}

A population is a collection of individuals belonging to the same species, living in the same area. Populations can be described by their age structure, which is the relative number of young and old individuals, or described by their size structure, which is based on the relative number of large and small individuals (Silvertown and Charlesworth 2001). Studying populations of long-lived woody plants is difficult because of time limitations. Therefore, size structure is sometimes used as a proxy for age structure. However, it is a mistake to assume a particular relationship between the size of tree and its age, without formally obtaining independent verification of that relationship (Harper 1977). Size is not only affected by age, but is also dependent on genetic differences and environmental/ physical differences in the local habitat. Nevertheless, studying the size structure of long-lived plants in a population may be very useful, because reproductive behavior of the plants may be more closely related to size than to age (Harper 1977). In addition, size may function as a good predictor of the amount of biomass each individual 
contributes to the fuel load. Total stand biomass is a combination of stand density and individual biomass, which is one aspect of the size of individual trees.

Perennial plants typically have an L-shaped frequency distribution, with many individual plants occurring in the smaller size-classes and fewer plants occurring in the larger size-classes (Silvertown and Charlesworth 2001). This distribution also referred to as a J-curve (Whittaker 1953), an inverse J-shape (Spring et al.1974), or a reverse "J"shape (Silva Matos et al.1999). If size-class is equivalent to age and if input to the smallest size-classes is constant, then the mortality and birth rates may be estimated from the size distribution.

Two alternative explanations explain how L-shaped size distributions may develop in even-aged populations. The first assumes no intraspecific competition and is based only on the observation that plant growth is exponential during its early phase (Silvertown and Charlesworth 2001). This means that rapid divergence can occur between plants with different starting sizes, turning an originally normal size distribution into an L-shaped one. An additional alternative explanation is that large plants suppress the growth of small ones (Silvertown and Charlesworth 2001). Many individuals remain small, while a few grow large and occupy a disproportionate amount of space. In such a population, size is not simply proportional to age.

\section{Mortality}

Two similar species of palms are found in the coastal sand dune scrub community of the Yucatan Peninsula of Mexico, Thrinax radiata Lodd ex J. A. \& J. M. Schult. and Coccothrinax readii Quero. Orellana and Ayora (1993) reported that T. radiata had a 
higher mortality rate in the early stages of development, whereas C. readii had a higher mortality rate in older stages. Olmsted and Alvarez-Buylla (2001) also studied T. radiata and $C$. readii in Quintana Roo, Mexico, and found that both species had a large percentage of individuals in the seedling size-class.

The mortality of palms as a result of prescribed fire is expected to be low because palms are fire-tolerant due to their lack of vulnerable meristematic tissue (McPherson and Williams 1998). Studies in fire-adapted ecosystems have shown that palms not only tolerate fire (McPherson and Williams 1998, Oba 1990) but in some cases were stimulated by it. For example, fire was shown to increase flowering in some species (Abrahamson 1999, Gunderson et al. 1983), including two long-lived palm species, Serenoa repens (Bartr.) Small (Saw Palmetto) and Sabal etonia Swinle ex Nash (Scrub Palmetto) at Archbold Biological Station in central Florida. These species quickly regained their preburn dominance after fire (Abrahamson 1984, 1995).

\section{Fuel Accumulation}

The amount of fuel present in an ecosystem is a function of the size structure and density of the plant populations and the amount of fuel each individual contributes. Fire plays a role in shaping all of these factors. Fire can cause mortality, thereby reducing density; it can also promote flowering, fruiting and seed germination, thereby adding individuals to the population. Fire also reduces the amount of fuel an individual plant contributes to an ecosystem, albeit temporarily. In fire prone ecosystems, the frequency of fire is determined by a combination of ignition source frequency and fuel load. Humans can more easily manage fuel loads than control ignition sources. Understanding 
how long it takes for an individual plant (palm) to accumulate fuel after fire and understanding the effect of fire on mortality and establishment are both essential to understanding the fire regime of an area.

\section{METHODS}

\section{Study Area}

The study site is located in the National Key Deer Refuge (NKDR) in the lower Florida Keys, Florida, USA. $\left(24^{\circ} 41^{\prime} \mathrm{N}, 81^{\circ} 22^{\prime} \mathrm{W}\right)$ (Figure 1). The total area of the NKDR is 3,460 hectares. It was established in 1957 with the main objective of protecting the endangered Key deer (United States Fish and Wildlife Service 2000). NKDR is administered by the United States Fish and Wildlife Service (USFWS), and is located approximately $260 \mathrm{~km}$ southwest of Miami. The largest island in the NKDR is Big Pine Key. Other large islands in the NKDR with pine forests include No Name Key, Sugarloaf Key, Little Pine Key, and Cudjoe Key (Figure 3).

Soil in undeveloped areas on Big Pine Keys, No Name Key, and Cudjoe are in the Keyvaca soil series: loamy-skeletal, carbonatic, isohyperthermic Lithic Rendolls and consist of well-drained soils that are shallow to rippable oolitic limestone bedrock (United States Department of Agriculture 1995). The soil on Sugarloaf is in the soil series Saddlebunch: loamy, carbonatic, isohyperthermic, shallow Tropic Fluvaquents. On Big Pine Key, Miami oolite limestone overlies Key Largo Limestone (Brown et al. 1990). The Key Largo Limestone is about 40-60,000 years older than the Miami Limestone, and also more permeable (Coniglio and Harrison 1983, Ross et al. 1992). The pine rocklands of Big Pine Key, No Name Key, Sugarloaf Key, and Cudjoe Key have little to no soil 
present and trees are rooted in fissures in the limestone (United States Department of Agriculture 1995, Ross et al. 2003).

The climate of the study area is characterized by hot, humid summers and warm, dry winters. The average annual rainfall in Key West, Florida, $48 \mathrm{~km}$ west of Big Pine Key, is $102 \mathrm{~cm}$, with $70 \%$ falling in the months May-August (Winsberg 2003). The highest monthly mean temperature $\left(29.1^{\circ} \mathrm{C}\right)$ occurs in August and the lowest $\left(20.7^{\circ} \mathrm{C}\right)$ in January (United States Department of Agriculture 1995). Temperatures below $5^{\circ} \mathrm{C}$ have never been recorded in the Lower Keys (Ross et al. 1992, citing pers. comm. with U.S. Weather Service, Winsberg 2003). Major hurricanes cross the area every few decades (National Weather Service-National Hurricane Center, NOAA 1930-1985, United States Department of Agriculture 1995). The most recent hurricanes were Hurricane Georges in September of 1998 and Hurricane Irene in October of 1999, both Category One hurricanes when they made landfall in the Keys (National Weather Service-National Hurricane Center).

The study sites are all located within pine rockland habitat. However, the lower Keys contain many additional types of vegetation. The natural areas of the lower Keys include hardwood hammocks, coastal mangroves, salt marshes, and freshwater wetlands. The vegetation of the area is mostly of West Indian origin but also contains species of northern American origin and many endemic herbs (Snyder et al.1990, Ross and Ruiz 1996).

\section{Field Methods}

I sampled nineteen sites, distributed among four different islands (Table 1 and Figure 3). Sixteen sites were located on Big Pine Key and single sites were located on 

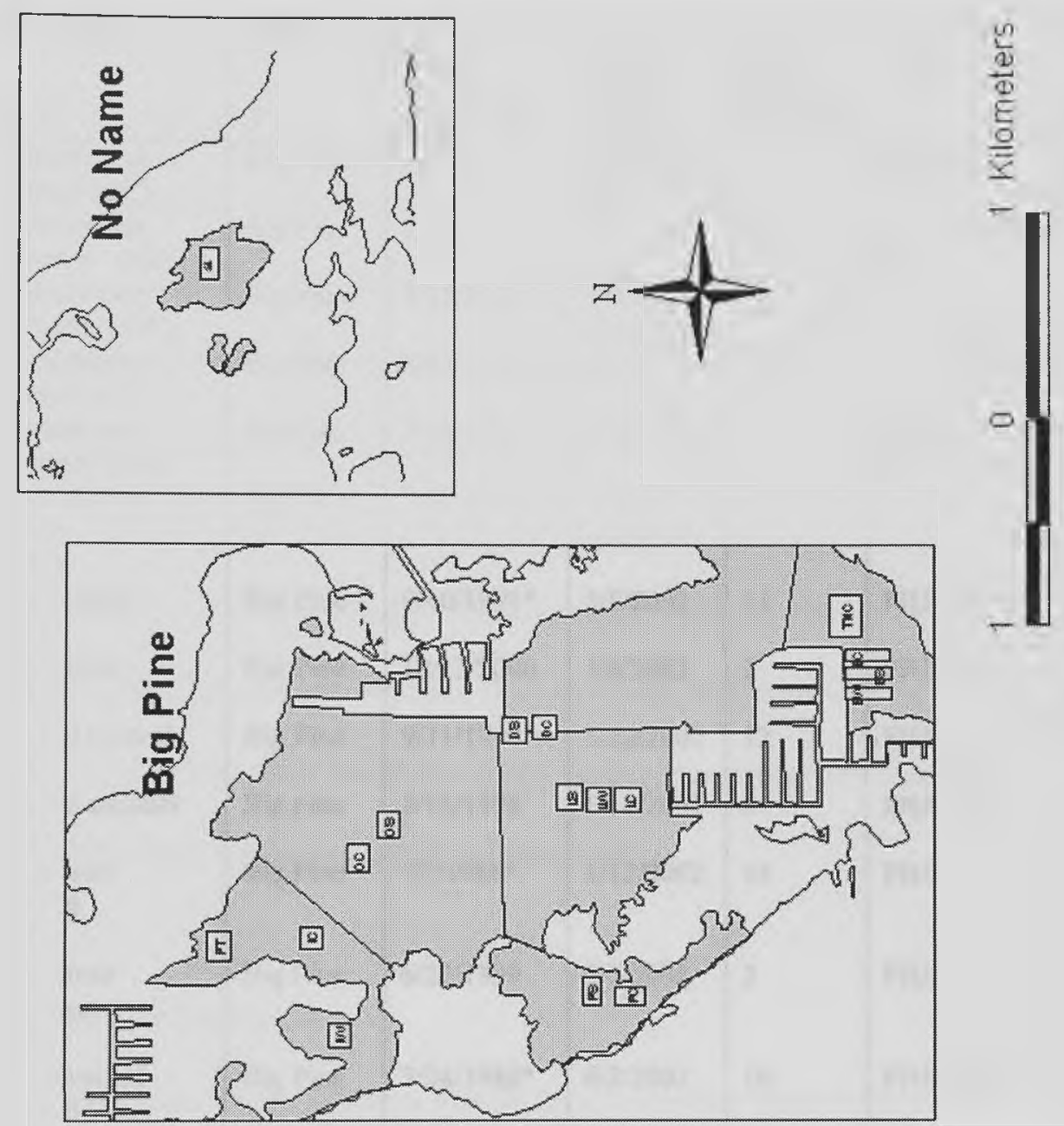

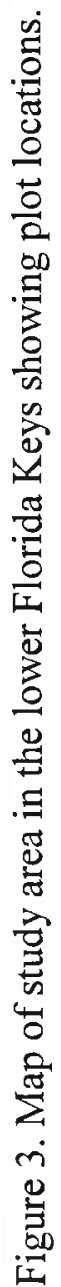


Table 1. Site names, island, burn dates, sampling dates and methods for 19study-sites located in the lower Florida Keys.

\begin{tabular}{|c|c|c|c|c|c|c|c|}
\hline Site name & Island & Last Burned & $\begin{array}{l}\text { Date } \\
\text { sampled } \\
\text { for fuel } \\
\text { amount }\end{array}$ & $\begin{array}{l}\text { Years } \\
\text { between } \\
\text { fire and } \\
\text { sampling }\end{array}$ & $\begin{array}{l}\text { Population } \\
\text { monitoring } \\
\text { type }\end{array}$ & $\begin{array}{l}\text { Fire } \\
\text { mor- } \\
\text { tality }\end{array}$ & Litter \\
\hline $\begin{array}{l}\text { Buttonwood } \\
\text { control (BC) }\end{array}$ & Big Pine & $>30 \mathrm{yrs} *$ & $5 / 1 / 2002$ & +30 & FIU/USGS & Yes & Yes \\
\hline $\begin{array}{l}\text { Buttonwood } \\
\text { summer (BS) }\end{array}$ & Big Pine & $7 / 18 / 2001$ & $4 / 28 / 2002$ & .75 & $\begin{array}{l}\text { HCC based on } \\
\text { FIU }\end{array}$ & Yes & Yes \\
\hline $\begin{array}{l}\text { Buttonwood } \\
\text { summer (BW) }\end{array}$ & Big Pine & $7 / 18 / 2001$ & $\begin{array}{l}{ }^{* *} \text { Not } \\
\text { sampled }\end{array}$ & & & Yes & No \\
\hline $\begin{array}{l}\text { Locustberry } \\
\text { control (LC) }\end{array}$ & Big Pine & $8 / 23 / 1986^{*}$ & $4 / 1 / 2002$ & 16 & FIU/USGS & Yes & Yes \\
\hline $\begin{array}{l}\text { Locustberry } \\
\text { summer (LS) }\end{array}$ & Big Pine & $7 / 19 / 2001$ & $3 / 2002$ & .67 & $\begin{array}{l}\text { HCC based on } \\
\text { FIU }\end{array}$ & Yes & Yes \\
\hline $\begin{array}{l}\text { Locustberry } \\
\text { winter } \\
(\mathrm{LW})\end{array}$ & Big Pine & $7 / 19 / 2001$ & $\begin{array}{l}* * \text { Not } \\
\text { sampled }\end{array}$ & & & Yes & No \\
\hline $\begin{array}{l}\text { Iris control } \\
\text { (IC) }\end{array}$ & Big Pine & $9 / 10 / 1991^{*}$ & $5 / 5 / 2002$ & 11 & FIU/USGS & Yes & Yes \\
\hline $\begin{array}{l}\text { Iris winter } \\
\text { (IW) }\end{array}$ & Big Pine & $12 / 12 / 2000$ & $5 / 4 / 2002$ & 2 & FIU/USGS & Yes & Yes \\
\hline $\begin{array}{l}\text { Orchid control } \\
\text { (OC) }\end{array}$ & Big Pine & 9/11/1990* & $5 / 22 / 2002$ & 12 & FIU/USGS & No & Yes \\
\hline $\begin{array}{l}\text { Orchid summer } \\
\text { (OS) }\end{array}$ & Big pine & $8 / 16 / 1998$ & $5 / 18 / 2002$ & 4 & FIU/USGS & No & Yes \\
\hline $\begin{array}{l}\text { Dogwood } \\
\text { control } \\
\text { (DC) }\end{array}$ & Big Pine & $? / ? / 1988^{*}$ & $5 / 12 / 2002$ & 14 & FIU/USGS & No & Yes \\
\hline $\begin{array}{l}\text { Dogwood } \\
\text { summer } \\
\text { (DS) }\end{array}$ & Big Pine & $6 / 22 / 1999$ & $5 / 8 / 2002$ & 3 & FIU/USGS & No & Yes \\
\hline $\begin{array}{l}\text { Poisonwood } \\
\text { control } \\
(\mathrm{PC})\end{array}$ & Big Pine & $7 / 24 / 1986^{*}$ & $6 / 2 / 2002$ & 16 & FIU/USGS & No & Yes \\
\hline $\begin{array}{l}\text { Poisonwood } \\
\text { summer } \\
\text { (PS) }\end{array}$ & Big Pine & $8 / 17 / 1998$ & $5 / 30 / 2002$ & 4 & FIU/USGS & No & Yes \\
\hline $\begin{array}{l}\text { NoName } \\
\text { (NN) }\end{array}$ & No Name & $>30^{*}$ & $5 / 23 / 2002$ & +30 & HCC-transect & No & Yes \\
\hline $\begin{array}{l}\text { Cudjoe } \\
\text { (CJ) }\end{array}$ & Cudjoe & $9 / 11 / 1991^{*}$ & $6 / 5 / 2002$ & 11 & HCC-transect & No & No \\
\hline $\begin{array}{l}\text { Sugarloaf } \\
\text { (SL) }\end{array}$ & Sugarloaf & $9 / 26 / 1987^{*}$ & $7 / 19 / 2001$ & 14 & HCC-transect & No & No \\
\hline $\begin{array}{l}\text { Terrestris } \\
\text { (TNC) }\end{array}$ & Big Pine & $6 / 7 / 1994^{*}$ & $5 / 29 / 2001$ & 7 & HCC-transect & No & No \\
\hline $\begin{array}{l}\text { Portpine } \\
\text { (PP) }\end{array}$ & Big Pine & $8 / 22 / 1986^{*}$ & $8 / 3 / 2001$ & 15 & HCC-transect & No & No \\
\hline
\end{tabular}

* Rocca (1997) Bergh and Wisby (1996) ${ }^{* *}$ Not sampled for fuel, only sampled for mortality. 
Sugarloaf, Cudjoe, and No Name Keys (Figure 3). Eighteen sites are managed by NKDR, and a single site on Big Pine Key is managed by The Nature Conservancy (TNC). Bergh and Wisby (1996) and Rocca (1997) reported the fire history of the NKDR based on Annual Narrative Reports. Additional information was provided by a survey of Key West Citizen newspaper articles and personal communication with Fire Chief Kip Watson of the Big Pine Key Volunteer Fire Department. A draft report combining the above sources of the Lower Keys fire history was then distributed among the scientists, resource managers and residents of the Lower Keys who had been directly or indirectly involved with fire for the past 20 years for their review. The final Bergh and Wisby (1996) report incorporates the comments and criticisms of these reviewers. The dates of the prescribed burns occurring during this study period are from records kept by the FIU/USGS study and personal observations.

\section{Population Structure}

Palm population structure was determined using three different, but related methods. The first method, used at ten sites, was developed from an ongoing fire effects study begun in 1998 by Florida International University and the United States Geological Survey (FIU/USGS) (Table 1). The FIU/USGS sites were one hectare, with 20 sampling locations distributed through a stratified random selection process. FIU/USGS personnel identified, counted and measured the height of all palms with the tallest leaf reaching $1 \mathrm{~m}$ tall within 4 meters of the 20 marked points ("shrub plots"). The total area sampled was therefore $1000 \mathrm{~m}^{2}$, or 0.1 ha. They also counted smaller individuals under one meter tall in four circular $1 \mathrm{~m}^{2}$ subplots ("herb plots") nested within each of the 20 larger plots 
described above. I divided the censused individuals from both of these surveys into the ten size-classes listed in Table 2. Many of the smaller palms (size-class 1) in the herb data were not identified to species, and only identified as "palm seedling". To estimate the number of each species in size-class 1 at each site, I simply apportioned the total number of unidentified seedlings among species according to the density-based percentage in the community at each site.

\begin{tabular}{ll}
\hline Table 2. Size-classes used in this study for palms. \\
Based on 0.5 meter apical meristem height intervals. \\
Apical meristem was estimated by measuring above \\
the dead leaves and slightly below the place of live \\
petiole attachment. \\
\hline size-class & apical meristem height (m) \\
\hline 1 & Seedling $\Rightarrow 0.01$ \\
2 & $0.01-0.5$ \\
3 & $0.51-1.0$ \\
4 & $1.01-1.5$ \\
5 & $1.51-2.0$ \\
6 & $2.01-2.5$ \\
7 & $2.51-3.0$ \\
8 & $3.01-3.5$ \\
9 & $3.51-4.0$ \\
10 & $4.01-4.5$ \\
\hline
\end{tabular}

Following methods modified from those used by FIU/USGS (Table 1), I sampled two additional sites (BS and LS) burned under prescription by the USFWS during the study period. As in the FIU/USGS method, all palms over one meter in leaf height in a 4-meter radius circular plot were measured. However, in the modified sampling method, all palms under 1 meter were counted and measured in a 2.525 meter circular radius plot at all 20 points, for a total sample area of $400 \mathrm{~m}^{2}$.

Finally, five additional sites (Table 1) were sampled using a third method (HCC). Sampling in this case utilized several randomly placed belt transects, 50 meters long and 
5 meters wide $\left(250 \mathrm{~m}^{2}\right)$. All palms with an apical meristem height of $0.5 \mathrm{~m}$ or more were counted and measured throughout the entire 5-meter belt. Palms with an apical meristem height under $0.5 \mathrm{~m}$ were counted in a 2 -meter wide belt, and palms without emerged stems were sampled at alternating 5-meter intervals along the same 2 -meter wide belt. Four transects were established at all five sites except at the Cudjoe Key site, where only two transects were sampled. The number of palm individuals in each size-class was counted by species at each site, and the number of individuals per size-class per hectare was estimated.

\section{Mortality, Growth and Reproduction}

The effect of fire on Coccothrinax argentata and Thrinax morrisii mortality was studied at eight sites in NKDR (Table 1). Eighty palms, 40 from each species, were tagged at each site. Twenty reproductive and non-reproductive individuals of each palm species across a wide range of sizes were selected at each site. Five of the eight sites were burned under prescription during the study. LS, LW, BS and BW were burned in July of 2001 and IW was burned in December of 2000. Three control sites, i.e. LC, BC, and IC did not burn during the time period of the study. Fire characteristics, burn dates, and burn histories all differed among the burn sites (Table 1). Tagged individuals in the five burned sites were revisited 6-7 months after the date of the fire, and their survival/mortality noted. The three unburned control sites were also sampled at approximately the same time. The tagged palms in the burn sites were then separated by species and size-class (Table 2) and plotted versus percent mortality, to determine if there was a pattern between mortality in burned sites and size. 
The same palms monitored for mortality in Iris Control (IC) and Iris Winter (IW) were also monitored for vegetative growth. The height to the apical meristem of each palm was first measured in late November or early December of 2000, and re-measured in December of 2002 .

\section{Aboveground Burnable Biomass Estimates}

Aboveground burnable biomass was estimated from regression models developed from 30 randomly selected plants (15 Coccothrinax and 15 Thrinax) representing a wide range of sizes, all located on Big Pine Key. In developing the regression models, the independent variables measured were height to the tallest leaf, height to the apical meristem, crown length $(\mathrm{CL})$, crown width $(\mathrm{CW})$, number of live leaves, number of dead leaves, and total number of leaves. Crown area (CA) was calculated as $\mathrm{CA}=\pi^{*}((\mathrm{CW}+\mathrm{CL}) / 4)^{2}$. After field measurements were taken, all live and dead leaves were pruned from the palms at the petiole base. Leaves and attached petioles were then placed in large paper bags and oven dried at $70^{\circ} \mathrm{C}$ to a constant weight. The dry weight was then obtained using a scale in the lab.

The best regression model was determined by using a combination of maximum $\mathrm{R}^{2}$ values and minimum absolute percentage deviation (Overman et al. 1994). Finney (1941), Baskerville (1971) and Beauchamp and Olson (1973) recognized that there is a bias introduced by log transformation. To eliminate the bias, the predicted biomass was multiplied by a correction factor, which is calculated from the standard error of estimate (SEE) of the regression (Sprugel 1983). 


\section{Fuel Accumulation Patterns}

For each palm species, ten individuals in each size size-class (Table 2) were randomly selected in each of the 17 sites. The same measurements used to develop the regressions, i.e., total height, apical meristem height, $\mathrm{CL}, \mathrm{CW}$, number of live leaves, and number of dead attached leaves were determined for each individual. Evidence of current or past reproduction was also noted. Palms were considered reproductive if they currently possessed reproductive inflorescences or if there was evidence of past inflorescences, including bracts. The amount of biomass an individual contributed was estimated by applying the best regression equation to the ten individuals per size-class per site and then obtaining the mean. The mean was then multiplied by the number of individuals per hectare to obtain the amount of biomass in $\mathrm{kg} / \mathrm{ha}$ for each site.

Palm litter was measured at 13 sites (Table 1) for the same ten individuals per sizeclass mentioned above. Loose palm litter was collected from around the base of the trees in the field and weighed in grams using a spring field scale. A portion of the litter was collected, reweighed in the field and brought back to the lab to dry in an oven $\left(70^{\circ} \mathrm{C}\right)$ until no change in weight was observed (approximately 4 days). The weight of the dried sample was subtracted from the original field weight to determine the moisture content of the collected palm litter, and subsequently applied to the total field weight to calculate dry litter weight under each tree. The average grams per individual for each of the sizeclasses was multiplied by the number of individuals per hectare in the corresponding size-class, and all size-classes were summed to obtain the total amount of litter per hectare. 


\section{Fuel Accumulation Curves}

The function of fuel load accumulation with time was modeled for live, dead attached and ground litter of each species using the equation:

$\mathrm{X}_{\mathrm{t}}=\mathrm{X}_{\mathrm{ss}}\left(1-\mathrm{e}^{-\mathrm{k}^{*} \mathrm{time}}\right)$

where $X_{t}$ is the fuel load accumulation at a given stand age, $X_{s s}$ the weight of fuel under steady-state conditions, and $\mathrm{k}$ the decomposition constant (McCaw et al. 2002).

Equations were fitted using the nonlinear regression program in the STATISTICA 6.0 statistical package.

\section{Leaf Moisture Content}

Moisture content of live and dead attached leaves and petioles were determined by randomly selecting 10 leaves ( 5 live and 5 dead) from 10 different palms of each species in three different study plots. The leaves were removed at the petiole base and placed in plastic bags to reduce evaporation. Immediately after returning to the lab, the petioles were clipped from the leaves and the samples were separated by location, species and leaf or petiole and then weighed and oven dried to a constant weight. The dry weight was determined and the percent moisture was calculated using the equation following Pietro et al. (2001):

$\%$ Moisture $=\frac{\mathrm{WW}-\mathrm{DW}}{\mathrm{DW}} * 100$

where WW=wet weight and DW=dry weight (Pietro et al. 2001).

The moisture content of the litter was determined by using the same litter collected for biomass determination. Approximately 300 grams was collected from both palm species 
on 13 different field days $(n=13)$. The percent moisture of the litter was determined using the methods described above for leaf moisture content.

\section{RESULTS}

\section{Population Structure}

The size distribution of Coccothrinax argentata and Thrinax morrisii in Buttonwood Control (BC) (Figure 4) represents a structure that was typical of most of the 17 sites (see Appendix A for palm population densities for individual study-sites). In both species, many individuals were present in the smallest size-classes, with fewer individuals in the larger size-classes. Size-classes 1 and 2 comprised $94 \%$ of the entire palm population for all sites, whereas size-classes 3-10 represent only $6 \%$ of the population (Table 3). Averaged across all sites, T. morrisii contained a larger percentage of individuals overall (55\% versus $45 \%$ for $C$. argentata). There were also T. morrisii present in the two largest size-classes; $C$. argentata contained no individuals in sizeclasses 9 or 10.

\begin{tabular}{|c|c|c|c|c|c|c|c|c|c|c|c|}
\hline Size-class & 1 & 2 & 3 & 4 & 5 & 6 & 7 & 8 & 9 & 10 & Total \\
\hline C. argentata/ha & 4,060 & 3,660 & 230 & 130 & 60 & 20 & 7 & 2 & 0 & 0 & 8,159 \\
\hline T. morrisiifha & 5,030 & 4,390 & 280 & 130 & 100 & 50 & 20 & 5 & 4 & 1 & 10,018 \\
\hline Total/ha & 9,090 & 8,050 & 510 & 160 & 160 & 70 & 27 & 7 & 4 & 1 & 18,177 \\
\hline
\end{tabular}




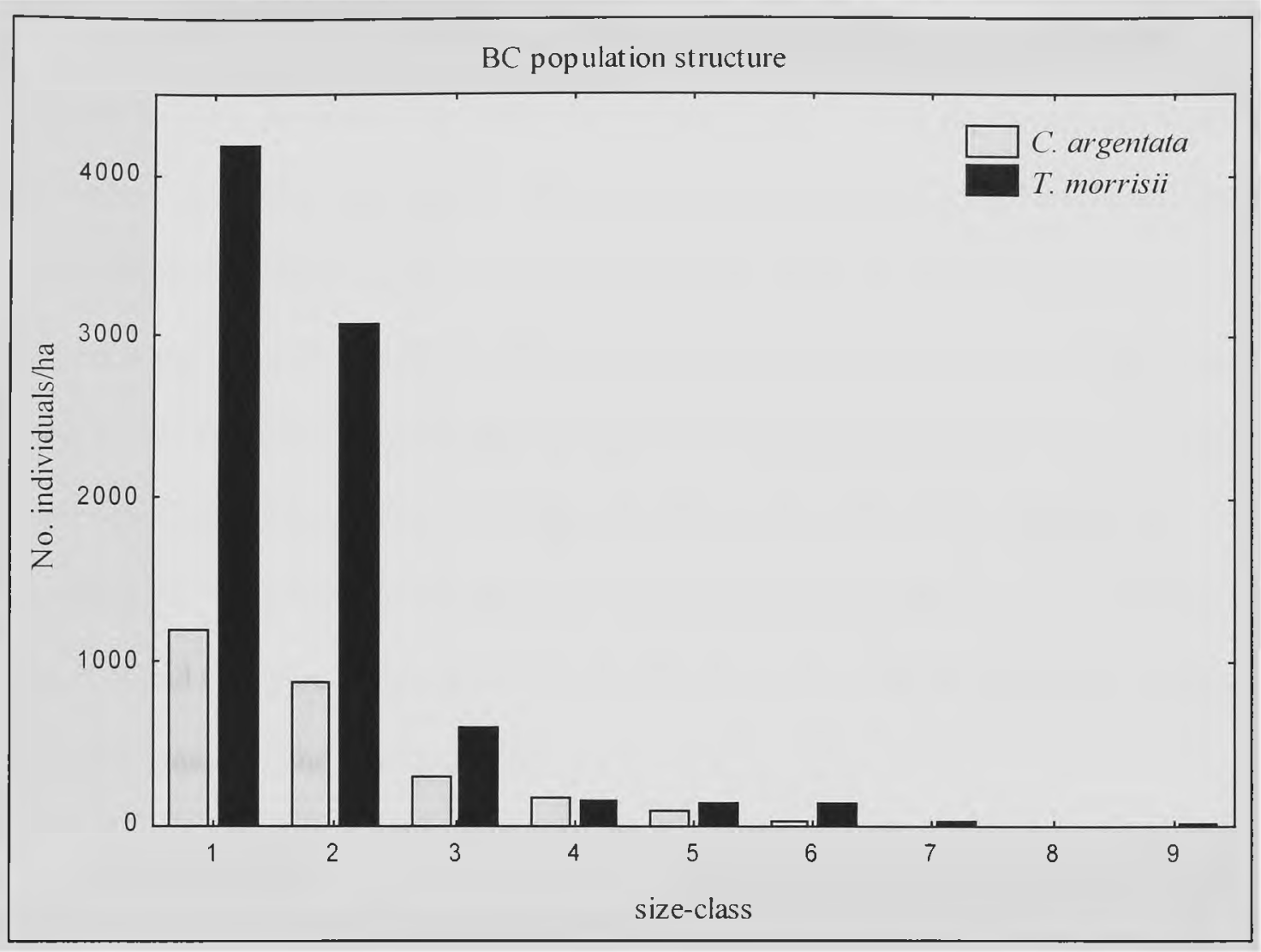

Figure 4. Coccothrinax argentata and Thrinax morrisii population structure on Buttonwood Control, located in the National Key Deer Refuge, on Big Pine Key in the lower Florida Keys. Buttonwood Control represents a typical population distribution for the two palms species in the study area. Showing an L-shaped population distribution, with many small individuals and few larger individuals. Size-classes are given in Table 2 based on 0.5 meter apical meristem increments in height. 
A few sites differed somewhat from the typical size structure represented by $\mathrm{BC}$ (Figure 4). In the No Name Key study site (Figure 5), there was a gap in the size structure of Thrinax morrisii in size-class 3. I also found a disproportionate number of individuals in the larger size-classes on No Name Key (Figure 5). This site was the only one to contain a size-class 10 individual and one of only five sites to include individuals in sizeclass 9. The Sugarloaf Key site (SL) contained a substantial number of T. morrisii, but almost no Coccothrinax argentata (Figure 6). There were only 10 C. argentata per hectare in SL, based on one sampled individual in size class 6 . The palm populations in Sites IW and OC were comprised of small individuals only, with no individuals larger than size-classes 5 and 6 , respectively.

\section{Population Density and Time Since Last Fire}

The population density of palms per hectare (excluding size-class 1) for both species at 17 sites was ranked in order of time since last fire (Figure 7). No obvious trend was observed in the relationship between time since last fire and population density. The palm population density varied from site to site, however this fluctuation seemed unrelated to time since last fire. The Poisonwood control (PC) site, which was burned 16 years before sampling, had the highest number of Coccothrinax argentata and Thrinax morrisii combined, at 31,500 per hectare. It was the only site out of the 17 to have over $20,000 \mathrm{C}$. argentata and T. morrisii combined per hectare. The other sites ranged from a low of 4,300 palms per hectare in TNC, burned 7 years before sampling, to 16,000 palms per hectare in PS, burned 3 years before sampling. 


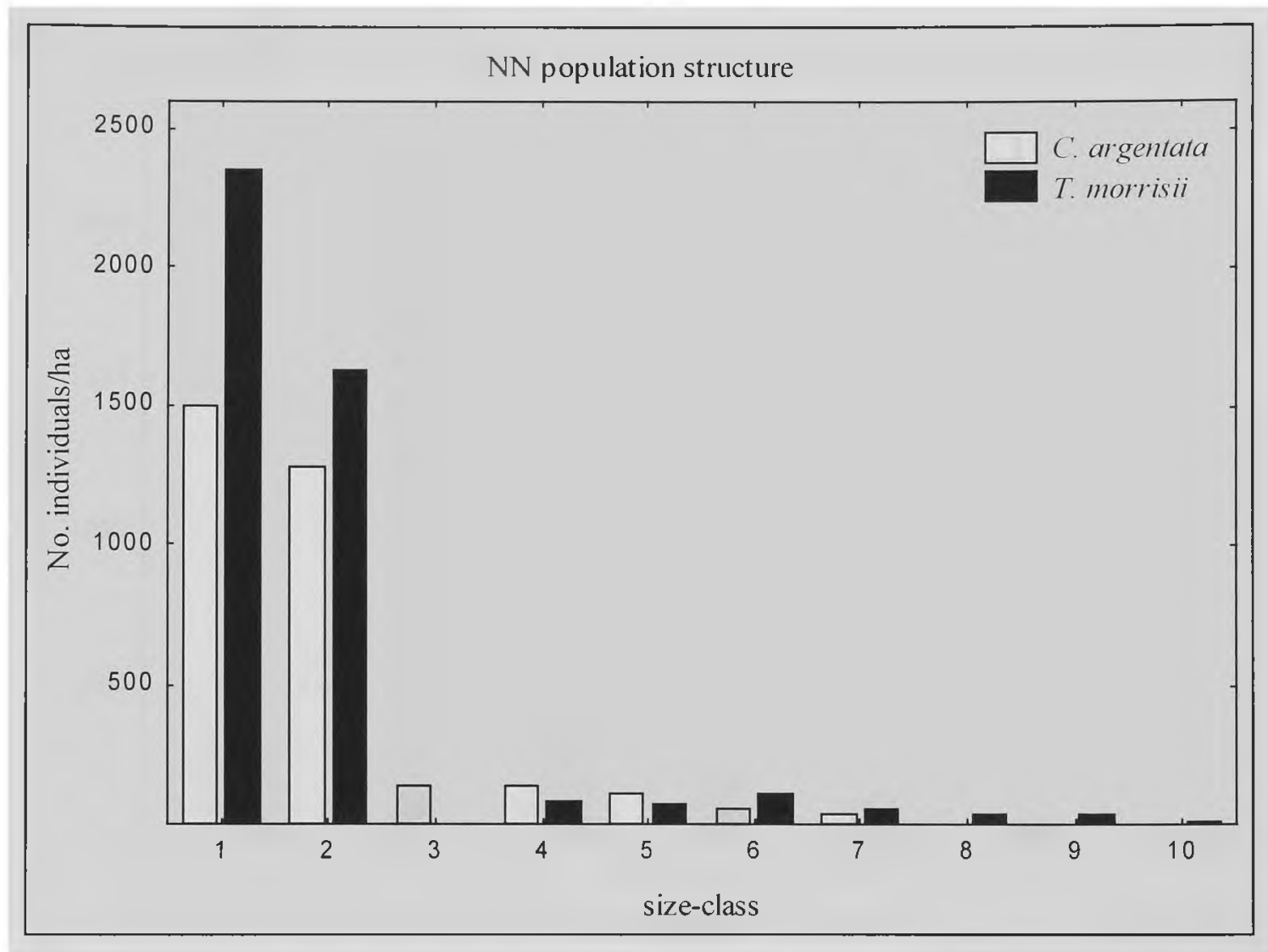

Figure 5. Coccothrinax argentata and Thrinax morrisii population structure on No Name Key study-site located in the National Key Deer Refuge, on No Key in the lower Florida Keys. No Name Key palm population distribution was similar to the population distribution of Buttonwood Control, however T. morrisii in size-class 3 showed lower numbers of individuals per hectare than did many of the following larger size-classes. Size-classes are given in Table 2 based on 0.5 meter apical meristem increments in height. 
SL population structure

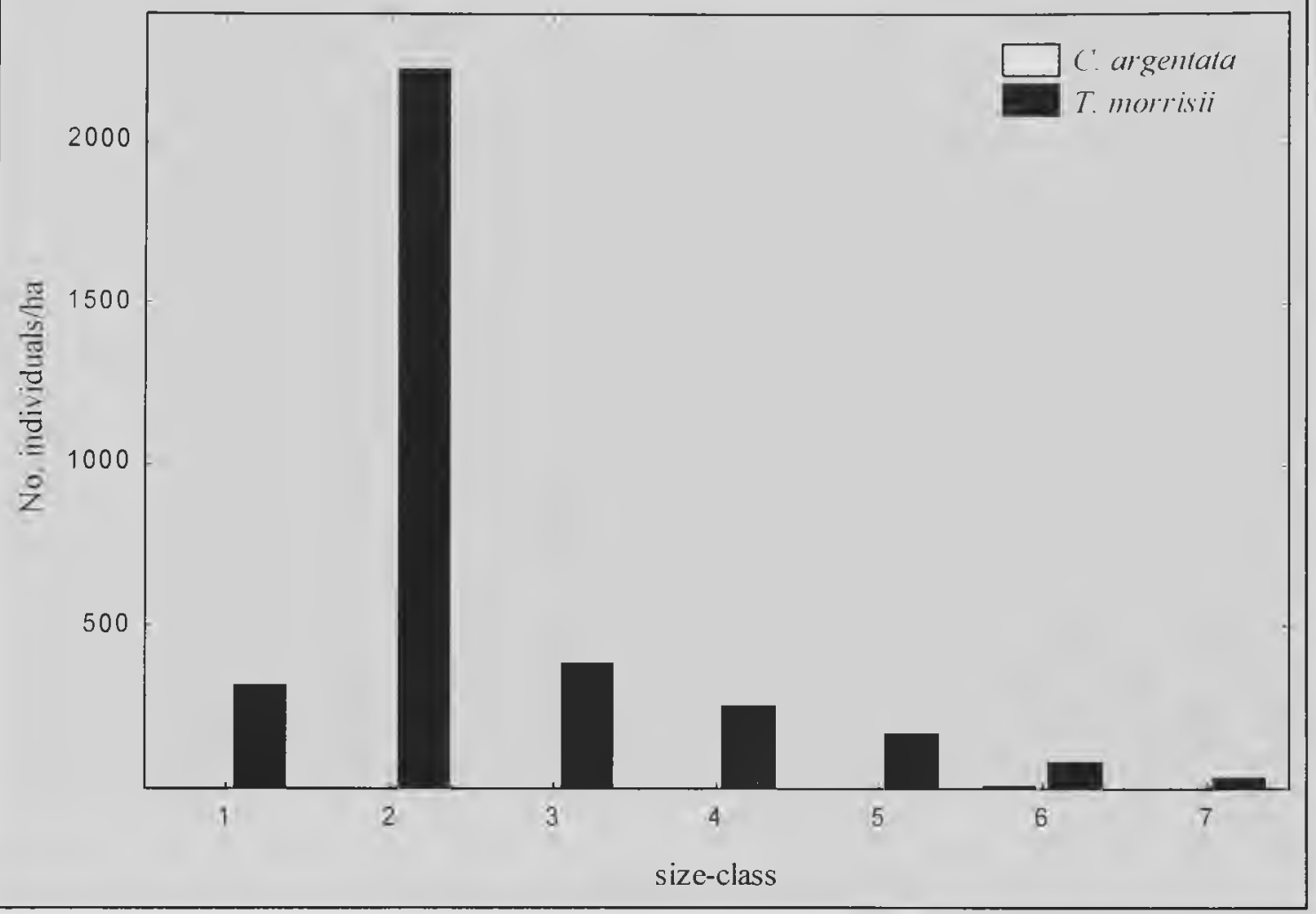

Figure 6. Coccothrinax argentata and Thrinax morrisii population structure on Sugarloaf study-site located in the National Key Deer Refuge, on Sugarloaf Key in the lower Florida Keys. Sugarloaf palm population showed very few C. argentata individuals with only a few occurring in size-class 6 and no C. argentata individuals observed in other size-classes. T. morrisii individuals in the smallest size-class were also lower than the next three larger size-class. Size-classes are given in Table 2 based on 0.5 meter apical meristem increments in height. 


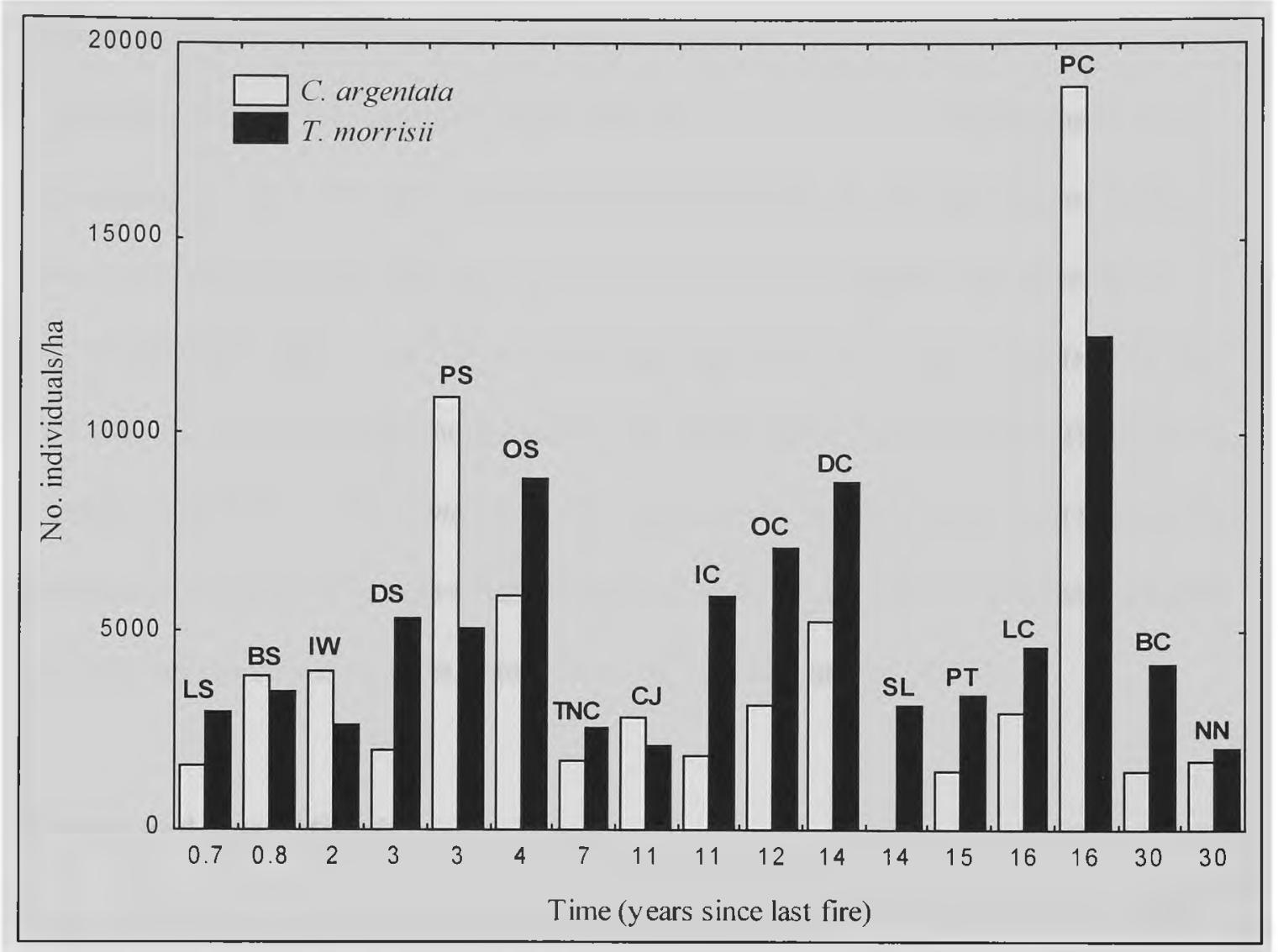

Figure 7. Coccothrinax argentata and Thrinax morrisii total population density, without size-class 1 , ranked in order of time since last fire. Capital letters at top of bars are site name abbreviations (reference table 1). No obvious pattern was observed between total palm population density and time since last fire. 


\section{Mortality}

Mortality rates of Coccothrinax argentata and Thrinax morrisii in unburned control plots during the ca 2-year period were very low, indicating low background mortality rates. In the control plots, only one individual of $243(0.4 \%)$ marked and recensused individuals died (Table 4) $(0.8 \%$ of the C. argentata and $0 \%$ of the T. morrisii). In the burn sites there was a higher mortality rate: 43 of the $409(10.5 \%)$ died $(13.2 \%$ of the $C$. argentata and $7.8 \%$ of the T. morrisii). The general pattern observed in both species was an increase in mortality as size-class increased (Figure 8). C. argentata showed a higher mortality rate in all size-classes than T. morrisii (Table 4 and Figure 8 ).

\section{Growth and Age Estimates}

Among the 160 tagged palms in the Iris plots, recorded apical meristem height growth for a two year period ranged from $-20 \mathrm{~cm}$ to $10 \mathrm{~cm}$ (Table 5). Negative readings, most likely from measurement error, were counted as zero growth. The majority of palms $(69 \%)$ showed no growth increase within the two-year period. $18 \%$ showed $10 \mathrm{~cm}$ or less growth in the two years and $13 \%$ died within the two years (see mortality section for further information). The maximum growth rate per year was $2.5 \mathrm{~cm}$ for Coccothrinax argentata and $5 \mathrm{~cm}$ for Thrinax morrisii (Table 5). For both species, a higher percentage of individuals exhibited positive growth in the unburned plots than in the burned plots.

Age for both palm species was estimated by extrapolation based on the relationship between stem growth rates and stem length. Using the maximum growth rate/year, an 
Table 4. Palm mortality-Number of palms surviving or dying as a function of fire treatment. (ca-1 year post fire and ca-2 years since initial sampling data). See appendix B for individual sites by reproductive status.

\begin{tabular}{|c|c|c|c|c|c|c|}
\hline Treatment & Species & Size-class & Died & Survived & Total & $\%$ killed \\
\hline \multirow[t]{16}{*}{ Control } & C. argentata & 1 & 0 & 8 & 8 & 0 \\
\hline & & 2 & 0 & 77 & 77 & 0 \\
\hline & & 3 & 0 & 13 & 13 & 0 \\
\hline & & 4 & 1 & 10 & 11 & 9.1 \\
\hline & & 5 & 0 & 7 & 7 & 0 \\
\hline & & 6 & 0 & 4 & 4 & 0 \\
\hline & & Total & 1 & 119 & 120 & 0.8 \\
\hline & T. morrisii & 1 & 0 & 3 & 3 & 0 \\
\hline & & 2 & 0 & 57 & 57 & 0 \\
\hline & & 3 & 0 & 12 & 12 & 0 \\
\hline & & 4 & 0 & 27 & 27 & 0 \\
\hline & & 5 & 0 & 16 & 16 & 0 \\
\hline & & 6 & 0 & 4 & 4 & 0 \\
\hline & & 7 & 0 & 3 & 3 & 0 \\
\hline & & 10 & 0 & 1 & 1 & 0 \\
\hline & & Total & 0 & 123 & 123 & 0 \\
\hline \multirow[t]{18}{*}{ Burn } & C. argentata & 1 & 1 & 16 & 17 & 5.9 \\
\hline & & 2 & 12 & 104 & 116 & 10.3 \\
\hline & & 3 & 5 & 24 & 29 & 17.2 \\
\hline & & 4 & 5 & 20 & 25 & 20.0 \\
\hline & & 5 & 3 & 7 & 10 & 30.0 \\
\hline & & 6 & 1 & 6 & 7 & 14.3 \\
\hline & & 7 & 0 & 1 & 1 & 0 \\
\hline & & Total & 27 & 178 & 205 & 13.2 \\
\hline & T. morrisii & 1 & 0 & 6 & 6 & 0 \\
\hline & & 2 & 6 & 80 & 86 & 7.0 \\
\hline & & 3 & 2 & 27 & 29 & 6.9 \\
\hline & & 4 & 3 & 32 & 35 & 8.6 \\
\hline & & 5 & 1 & 24 & 25 & 4.0 \\
\hline & & 6 & 1 & 13 & 14 & 7.1 \\
\hline & & 7 & 2 & 3 & 5 & 40.0 \\
\hline & & 8 & 1 & 2 & 3 & 33.3 \\
\hline & & 10 & 0 & 1 & 1 & 0 \\
\hline & & Total & 16 & 188 & 204 & 7.8 \\
\hline
\end{tabular}




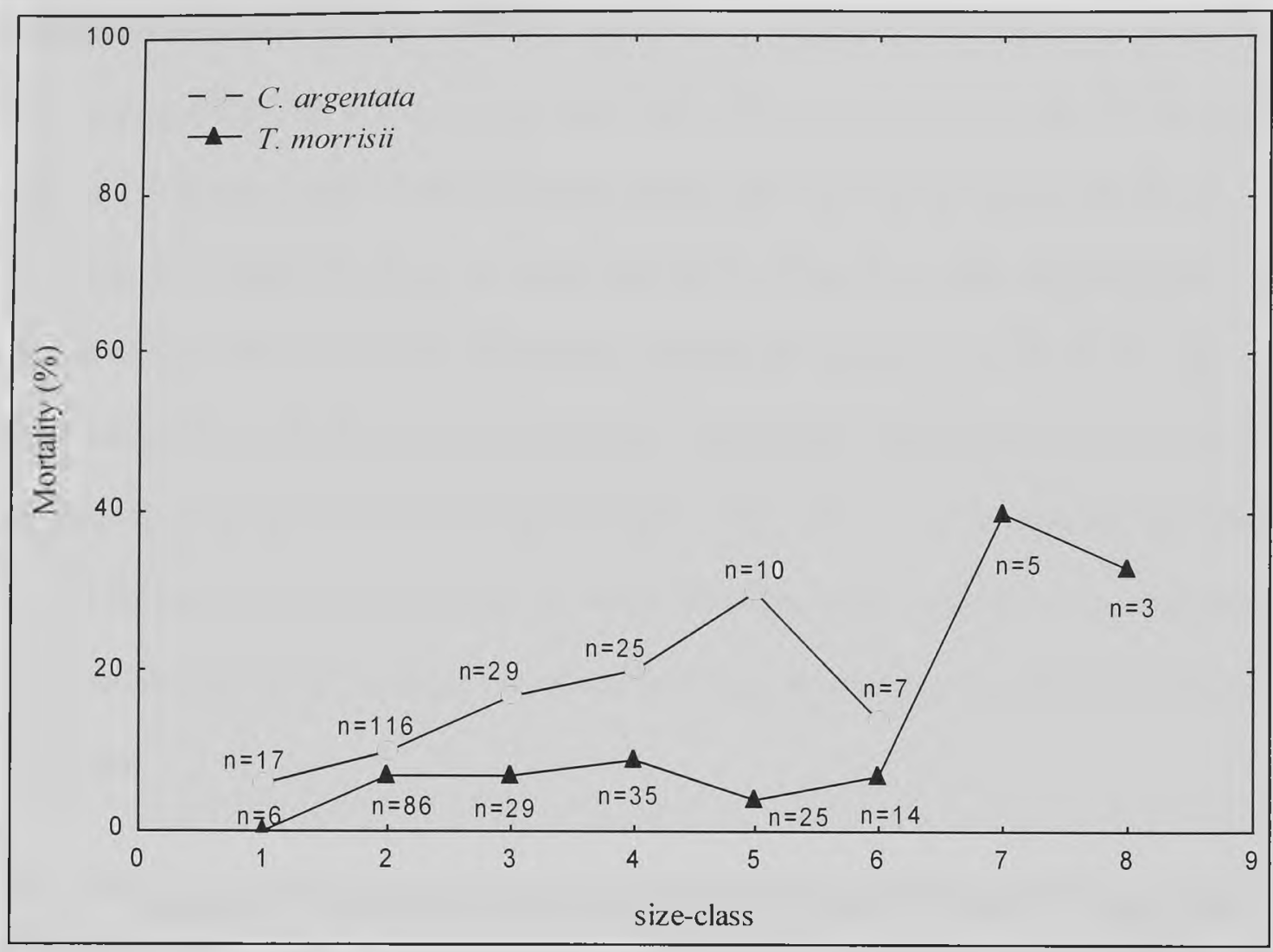

Figure 8. Observed percent mortality of Coccothrinax argentata and Thrinax morrisii 67 months after fire by size-classes shown in Table 2. $\mathrm{n}=$ sum of all 5 burn sites in the NKDR located in the lower Florida Keys that burned during my study period (BS, BW, IW, LS, LW). Sample size ranged from 3-116. Data not shown for size-classes with $<3$ palms. In the control sites only one individual out of 243 died in the ca-2 year monitoring period. See appendix B for individual sites by reproductive status. 
estimated minimum age was obtained. The tallest $C$. argentata individual was found in the No Name Key site with an apical stem height of $3.4 \mathrm{~m}$. Assuming a maximum growth rate of $2.5 \mathrm{~cm} /$ year, a minimum age for this individual would be 136 years old. For $T$. morrisii, the largest individual was also found on No Name Key with an apical stem height of 4.2 meters; assuming a maximum growth rate of $5 \mathrm{~cm} /$ year, a minimum age estimate for this individual would be 84 years. Assuming (1) no establishment phase and (2) growth at the same maximum rate throughout life, a minimum estimate for the stand age of the palms is between 84 and 136 years. However, since both of these assumptions are contradicted by the literature on palms, these must be considered underestimates of palm age.

Table 5. Growth rate of tagged palms monitored in Iris Control (IC) and Iris Winter (IW) during a 2-year time period.

\begin{tabular}{|c|c|c|c|c|c|c|}
\hline & & Measured grow & in two years & m) Dec 2000-De & 2002 & \\
\hline Site & Species & $\begin{array}{l}0 \mathrm{~cm} \\
\#(\%)\end{array}$ & $\begin{array}{l}5 \mathrm{~cm} \\
\#(\%)\end{array}$ & $\begin{array}{l}10 \mathrm{~cm} \\
\#(\%)\end{array}$ & $\begin{array}{l}\text { Dead } \\
\#(\%)\end{array}$ & Total \\
\hline IC & C.argentata & $31(78 \%)$ & $8(20 \%)$ & $0(0 \%)$ & $1(2.5 \%)$ & 40 \\
\hline IC & T. morrisil & $24(60 \%)$ & $13(33 \%)$ & $3(8 \%)$ & $0(0 \%)$ & 40 \\
\hline IW & C.argentata & $28(70 \%)$ & $2(5 \%)$ & $0(0 \%)$ & $10(25 \%)$ & 40 \\
\hline IW & T. morrisii & $28(70 \%)$ & $2(5 \%)$ & $1(2.5 \%)$ & $9(23 \%)$ & 40 \\
\hline Total & & $111(69 \%)$ & $25(16 \%)$ & $4(2.5 \%)$ & $20(13 \%)$ & 160 \\
\hline
\end{tabular}

\section{Reproductive Status Versus Size-Class}

The percentage of individuals of reproductive status in each size class, across all sites at the time of initial sampling, was determined (Table 6). Coccothrinax argentata reached reproductive status at a smaller size than Thrinax morrisii. No reproductive structures were observed on C. argentata individuals until they reached size-class two. At size-class three and above, all individuals of this species showed evidence of reproductive activity. Therefore, an approximate apical meristem height reached for reproductive activity to 
occur in C. argentata would be $0.5 \mathrm{~m}$. No individuals of T. morrisii in size-classes 1 or 2 showed evidence of reproductive activity. At size-class three, $23.1 \%$ were reproductive. It was not until size-class 5 and above that all individuals showed signs of reproduction. The estimated apical meristem height needed for the initiation of reproductive activity in T. morrisii is therefore between $0.51 \mathrm{~m}$ and $1.51 \mathrm{~m}$.

\begin{tabular}{|c|c|c|c|c|c|c|c|c|c|c|}
\hline Size-class & 1 & 2 & 3 & 4 & 5 & 6 & 7 & 8 & 9 & 10 \\
\hline \multirow[t]{2}{*}{ C.argentata } & 0 & 26.2 & 100 & 100 & 100 & 100 & 100 & 100 & 100 & 100 \\
\hline & (154) & $(317)$ & (147) & (135) & (119) & (72) & (35) & (5) & (0) & (0) \\
\hline \multirow[t]{2}{*}{ T. morrisii } & & 0 & 23.1 & 99.3 & 100 & 100 & 100 & 100 & 100 & 100 \\
\hline & (144) & (307) & (151) & $(156)$ & (147) & (109) & (78) & (34) & (13) & (6) \\
\hline
\end{tabular}

\section{Aboveground Burnable Biomass Estimates}

Regression models were developed for live, dead, and total attached aboveground burnable biomass for each of the species. Statistics for equations modeling total biomass are presented in Table 7, and statistics for live and dead biomass models are presented in Appendices $\mathrm{C}$ and D. Multiple regression analysis of all the measured predictors (CA, height, apical height, and number of leaves for live, attached dead and total) with total biomass indicated that crown area and the number of leaves were the best individual predictors (Table 7). The combination of these two variables also produced the best 2factor models, based on several criteria, i.e., maximizing $\mathrm{R}^{2}$ or minimizing the absolute percentage deviation (Overman et al. 1994). The absolute percentage deviation is based on the ratio between the estimated and observed biomass. Logarithmic transformations of both dependent and independent variables improved the models further, especially according to the absolute percentage deviation criterion (Table 7). Log transformation 
Table 7. Comparison of criteria used to determine best regression model for the prediction of total

Coccothrinax argentata and Thrinax morrisii aboveground, oven-dried, burnable biomass in the

lower Florida Keys.

$\mathrm{R}^{2}$ and absolute \% deviation were used to determine best regression model. $\quad \mathrm{N}=15$ for both species.

See Appendices C and D for live and dead.

*Absolute percentage deviation $=\Sigma$ estimated dry weight-observed dry weight $\mid * 100$

(Overman, 1994) Observed dry weight

\begin{tabular}{|c|c|c|c|c|c|}
\hline Dependent & Independent & $p$-value & SEE & $\mathrm{R}^{2}$ & *Absolute $\%$ Deviation \\
\hline \multicolumn{6}{|c|}{ Coccothrinax argentata } \\
\hline Total wt (g) & area & 0.001 & 421.77 & 0.567 & 80.1 \\
\hline Total wt (g) & height & 0.156 & 591.48 & 0.149 & 166.3 \\
\hline Total wt (g) & apical height & 0.27 & 610.60 & 0.093 & 216.1 \\
\hline Total wt $(g)$ & total Hleaves & $<0.001$ & 386.90 & 0.636 & 106.1 \\
\hline Total wt (g) & area+height & 0.003 & 414.13 & 0.615 & 50.3 \\
\hline Total wt (g) & areatapical height & 0.004 & 419.84 & 0.604 & 60.9 \\
\hline Total wt (g) & area + total \# lvs & $<0.001$ & 258.26 & 0.85 & 90.8 \\
\hline Total wt $(\mathrm{g})$ & height + total \# lvs & $<0.001$ & 321.77 & 0.767 & 73.7 \\
\hline Total wt $(\mathrm{g})$ & apical height+total \# Ivs & $<0.001$ & 330.43 & 0.755 & 53.9 \\
\hline $\ln ($ Total wt)(g) & $\ln ($ area) & $<0.001$ & 0.51 & 0.821 & 45.8 \\
\hline In $($ Total wt $)(g)$ & In (height) & 0.003 & 0.85 & 0.503 & 117.8 \\
\hline ln $($ Total wt)(g) & In (apical height) & 0.004 & 0.87 & 0.488 & 128.9 \\
\hline In $($ Total wt)(g) & In (\# total leaves) & 0.001 & 0.76 & 0.606 & 100.0 \\
\hline $\ln ($ Total wt) $(\mathrm{g})$ & $\ln ($ area $)+\ln ($ height $)$ & $<0.001$ & 0.52 & 0.83 & 46.6 \\
\hline In $($ Total wt)(g) & In (area) $+\ln$ (apical height) & $<0.001$ & 0.52 & 0.83 & 46.2 \\
\hline $\ln ($ Total wt)(g) & $\ln ($ area $)+\ln ($ total \#lvs) & $<0.001$ & 0.28 & 0.95 & 19.6 \\
\hline $\ln ($ Total wt)(g) & $\ln ($ height $)+\ln$ (total \#lvs) & $<0.001$ & 0.35 & 0.923 & 28.2 \\
\hline $\ln ($ Total wt $)(\mathrm{g})$ & In (apical height) $+\ln ($ total\#lvs) & $<0.001$ & 0.36 & 0.919 & 29.9 \\
\hline \multicolumn{6}{|c|}{ Thrinax morrisii } \\
\hline Total wt $(\mathrm{g})$ & area & $<0.001$ & 2203.13 & 0.779 & 170.9 \\
\hline Total wt (g) & height & 0.026 & 3845.81 & 0.325 & 1150.9 \\
\hline Total wt (g) & apical height & 0.086 & 4163.45 & 0.209 & 1988.1 \\
\hline Total wt (g) & total \# leaves & $<0.001$ & 1500.67 & 0.897 & 88.6 \\
\hline Total wt $(\mathrm{g})$ & area + height & $<0.001$ & 2236.02 & 0.79 & 129.4 \\
\hline Total wt (g) & area+apical height & $<0.001$ & 2200.93 & 0.796 & 125.3 \\
\hline Total wt $(\mathrm{g})$ & area+total \# Ivs & $<0.001$ & 1015.77 & 0.957 & 366.5 \\
\hline Total wt (g) & height+ total \# lvs & $<0.001$ & 1491.87 & 0.906 & 270.4 \\
\hline Total wt (g) & apical height +total \# lvs & $<0.001$ & 1517.17 & 0.903 & 176.4 \\
\hline In (Total wt) (g) & $\ln ($ area) & $<0.001$ & 0.40 & 0.966 & 36.8 \\
\hline In (Total wt) (g) & $\ln$ (height) & $<0.001$ & 0.94 & 0.812 & 152.5 \\
\hline $\ln ($ Total wt) (g) & In (apical height) & $<0.001$ & 0.95 & 0.811 & 151.0 \\
\hline $\ln ($ Total wt) (g) & In (\# total leaves) & $<0.001$ & 0.76 & 0.879 & 94.3 \\
\hline $\ln ($ Total wt) $(\mathrm{g})$ & $\ln$ (area) $+\ln$ (height) & $<0.001$ & 0.34 & 0.978 & 27.0 \\
\hline ln (Total wt) (g) & $\ln ($ area $)+\ln ($ apical height $)$ & $<0.001$ & 0.31 & 0.982 & 24.2 \\
\hline $\ln ($ Total wt) $(\mathrm{g})$ & $\ln ($ area) $+\ln ($ total Hlvs) & $<0.001$ & 0.36 & 0.975 & 27.5 \\
\hline $\ln ($ Total wt) (g) & $\ln ($ height) $+\ln ($ total 杫lvs) & $<0.001$ & 0.54 & 0.944 & 50.6 \\
\hline $\ln ($ Total wt) (g) & $\ln$ (apical height) $+\ln$ (total\#lvs) & $<0.001$ & 0.54 & 0.943 & 50.8 \\
\hline
\end{tabular}


was also necessary to improve the heteroscedasticity common in size-weight

relationships, where the standard deviation increases with respect to weight increase.

Similar results were obtained for models predicting live and dead biomass (Appendices C and D).

The best equations for predicting live, dead and total attached biomass for both palm species are shown in Table 8. To eliminate the bias caused by the logarithmic transformation, each predicted value was multiplied by a correction factor calculated from the standard error of estimate (SEE) of the regression (Sprugel 1983).

Table 8. Best regression models, based on criteria shown in table 7, for prediction of live, dead attached and total oven-dried leaf biomass for two palm species, in the NKDR of the lower Florida Keys. Correction factor (Sprugel 1983) $\mathrm{CF}=\exp \left(\mathrm{SEE}^{2} / 2\right)$

\begin{tabular}{|c|c|c|c|c|}
\hline For C. argentata & Equation & $\mathrm{R}^{2}$ & $\mathrm{n}$ & $\overline{C F}$ \\
\hline Live & $\ln B=0.9817 \operatorname{lnCA}+1.4675 \operatorname{lnLL}+2.1145$ & 0.972 & 15 & 1.02 \\
\hline Dead & $\ln B=1.392 \operatorname{lnCA}+0.739 \operatorname{lnDL}+3.715$ & 0.903 & 15 & 1.08 \\
\hline Total & $\ln \mathrm{B}=1.255 \ln \mathrm{CA}+1.016 \ln \mathrm{TL}+3.121$ & 0.950 & 15 & 1.04 \\
\hline \multicolumn{5}{|l|}{ For T. Morrisii } \\
\hline Live & $\ln B=1.128 \ln C A+0.959 \ln L L+3.257$ & 0.975 & 15 & 1.06 \\
\hline Dead & $\ln B=1.367 \ln C A+0.808 \ln D L+3.23$ & 0.965 & 15 & 1.11 \\
\hline Total & $\ln B=1.282 \ln C A+0.777 \ln T L+3.656$ & 0.975 & 15 & 1.07 \\
\hline
\end{tabular}

\section{Fuel Accumulation Patterns}

By applying the equations of Table 8 to the structural data collected in the field, I estimated the mean dry weight of live and dead attached burnable biomass per individual for both species in all size-categories, averaged across all sites. Figures 9 and 10 combine these estimates with direct measurements of litter biomass for Coccothrinax argentata and Thrinax morrisii, respectively. The total burnable biomass contributed by individual 
palms of both species in size-classes 1 and 2 was negligible. The amount an individual $C$. argentata contributed to increase until size-class 3 and then levels off to a relatively constant amount for the higher size-classes. T. morrisii continued to increase until sizeclass 4 and then leveled off to a relatively constant amount beyond that point. Litter contributed by both species was a smaller amount per individual than attached biomass; litter biomass leveled off at around size-class 5 for $C$. argentata and size-class 6 for $T$. morrisii. (Note the ten times larger scale of the y-axis of $T$. morrisii versus $C$. argentata in Figures 9 and 10).

By combining the size-specific estimates of the three biomass components (Figures 9 and 10) with the estimates of density averaged across all sites, Figures 11 and 12 illustrate the contributions of different size-classes to burnable biomass of Coccothrinax argentata and Thrinax morrisii in lower Keys pine forests. Even though size-class one contributed the highest number of individuals to the population structure, the average amount in grams contributed by each individual was very low $(7.07 \mathrm{~g}$ for $C$. argentata and $6.06 \mathrm{~g}$ for T. morrisii) and when combined with the number of individuals did not contribute a significant amount of fuel. However, in both species, size-class 2 individuals contributed the highest amount of total fuel, despite a relatively low contribution per individual, In C. argentata, size-classes beyond 1 meter in apical height, i.e., size-class 3, contributed relatively little fuel (Figure 11), but in T. morrisii categories up to about 3 meters in apical height, size-class 8 , contributed a substantial quantity of fuel to the environment (Figure 12). See appendix E for total amount of attached burnable fuel and appendix $\mathrm{F}$ for litter per site contributed by $C$. argentata and T. morrisii. 


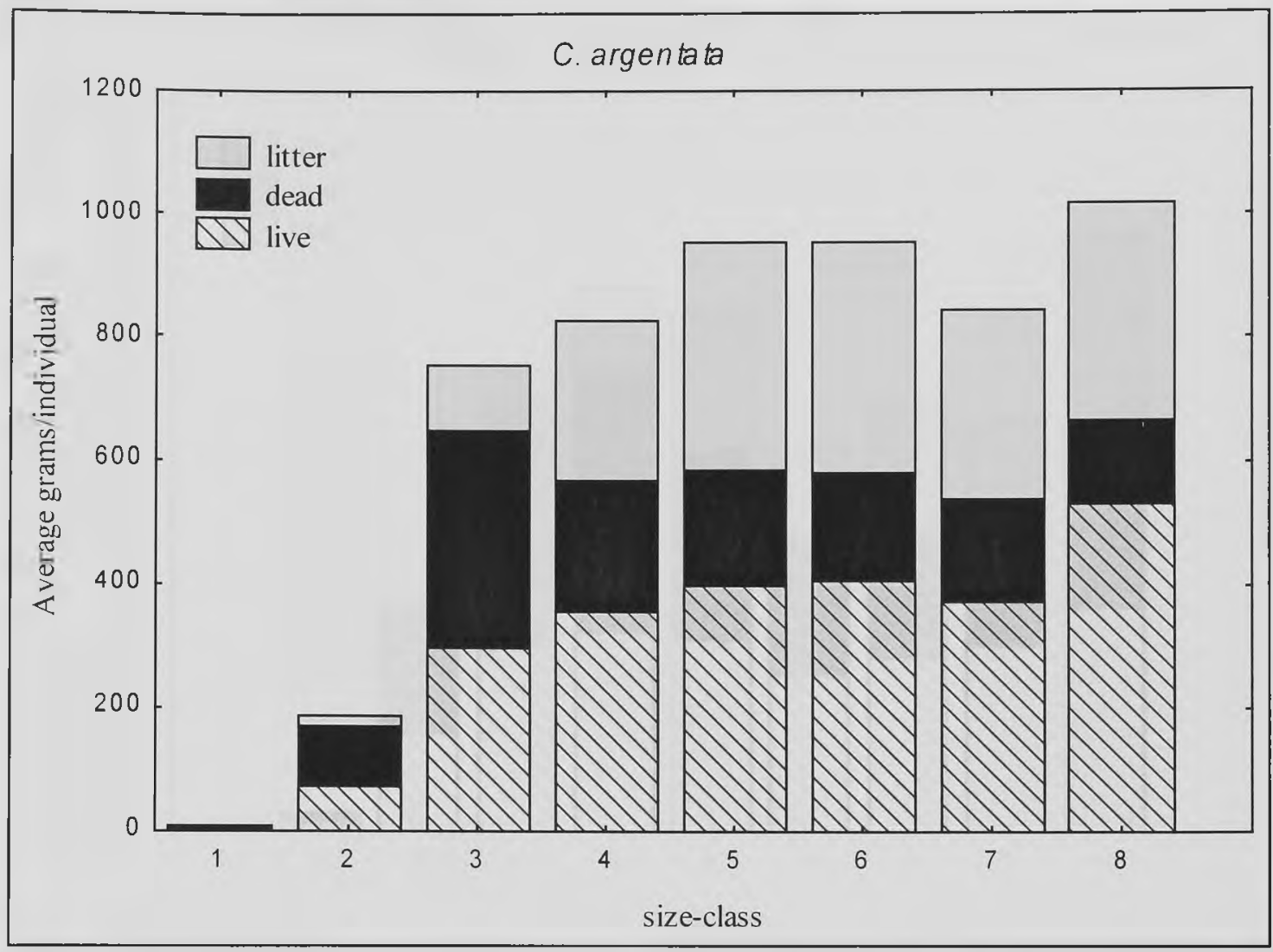

Figure 9. Coccothrinax argentata average grams per individual of oven-dried burnable biomass for live, dead attached and litter components by size-class (Table 2) in the NKDR of the lower Florida Keys, based on study-sites sampled for fuel (Table 1). 


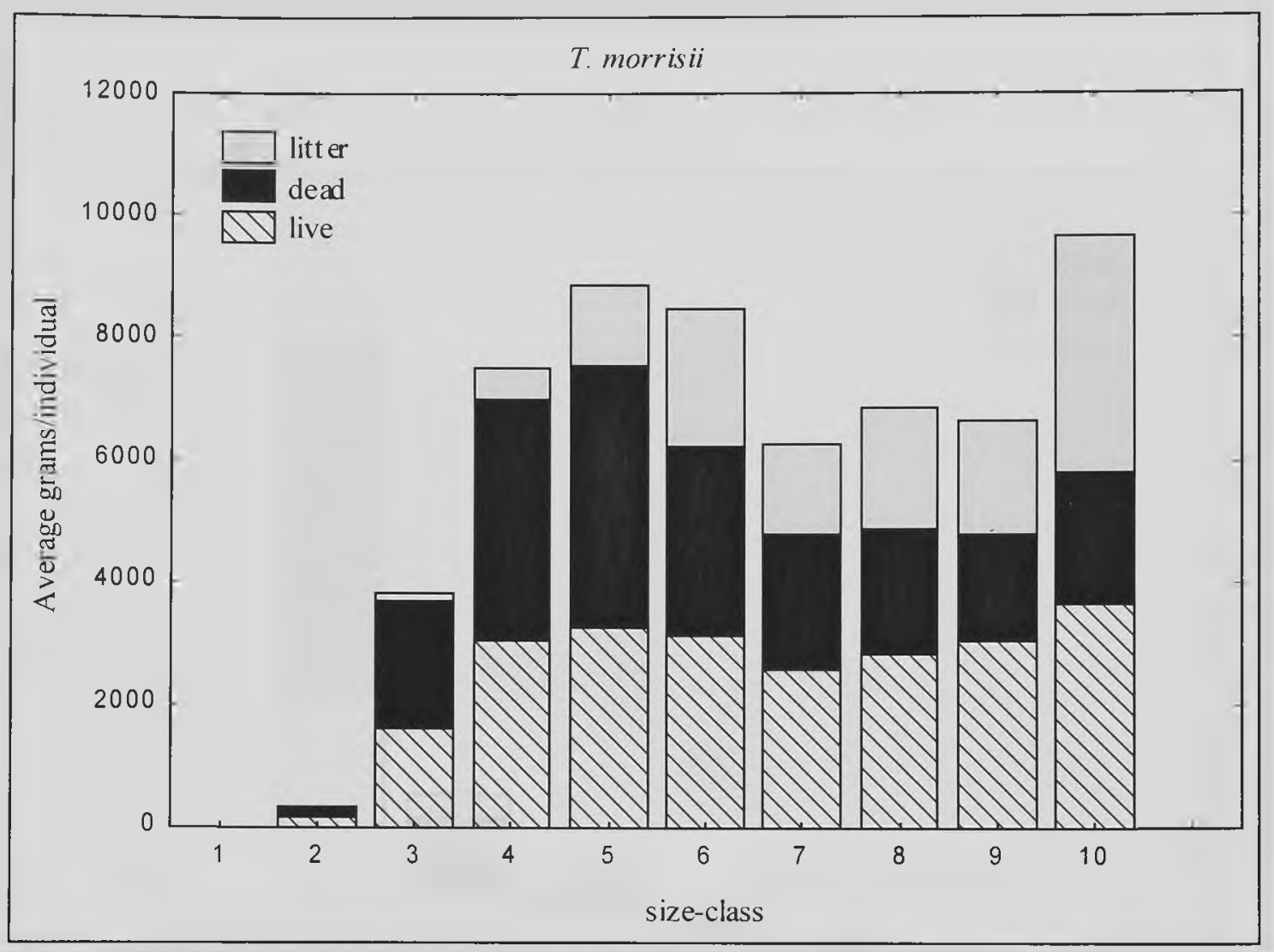

Figure 10. Thrinax morrisii average grams per individual of oven-dried burnable biomass for live, dead attached and litter components by size-class (Table 2) in the NKDR of the lower Florida Keys, based on study-sites sampled for fuel (Table 1). 


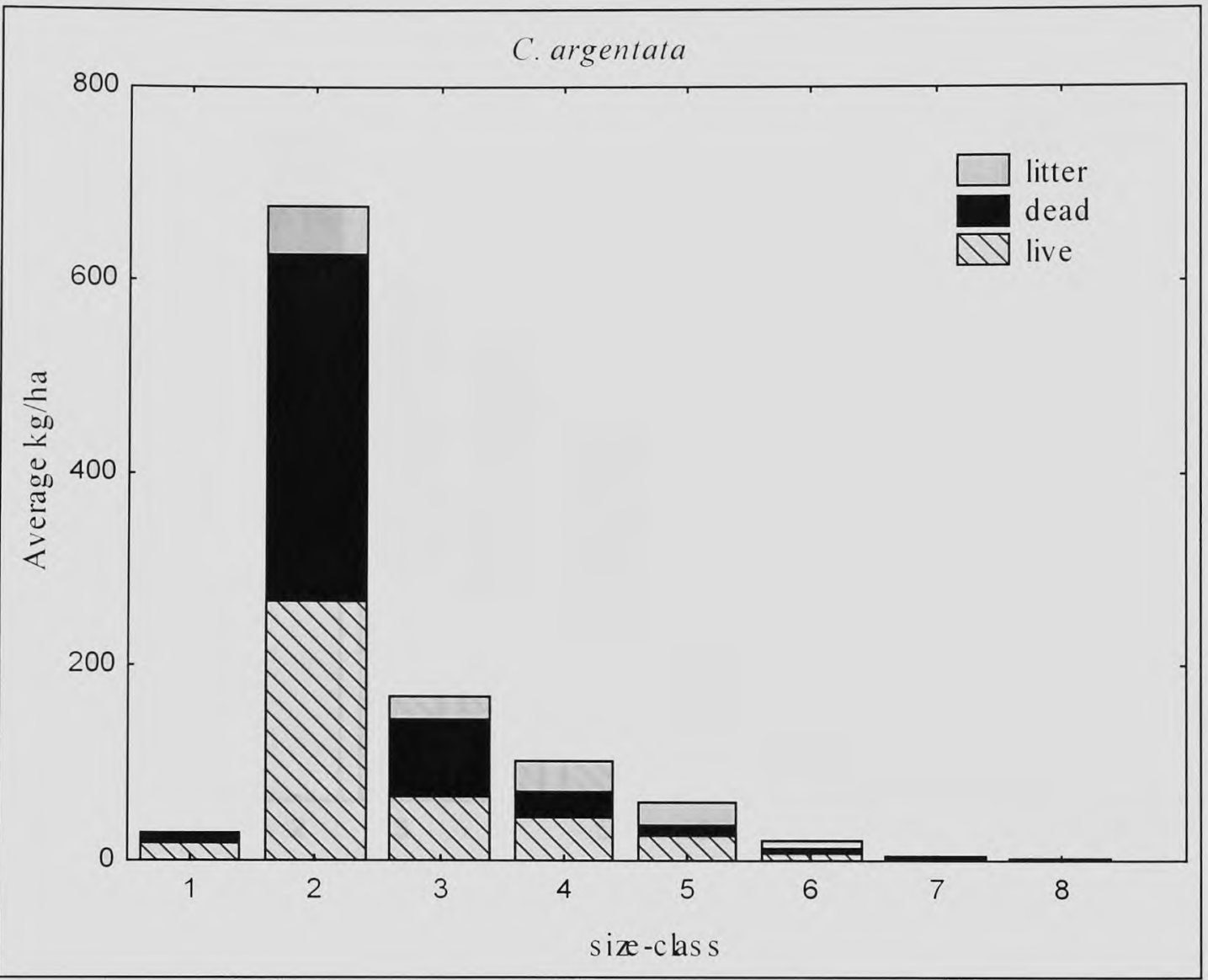

Figure 11. Coccothrinax argentata $\mathrm{kg} / \mathrm{ha}$ of oven-dried burnable biomass for live, dead attached and litter by size-class (Table 2) in the NKDR of the lower Florida Keys, based on study-sites sampled for fuel (Table 1). Kg/ha was obtained by multiplying the average grams/individual for each size-class (Figure 9) of the three biomass components with the average estimated density of $C$. argentata per hectare by size-class (Table 3 ). 


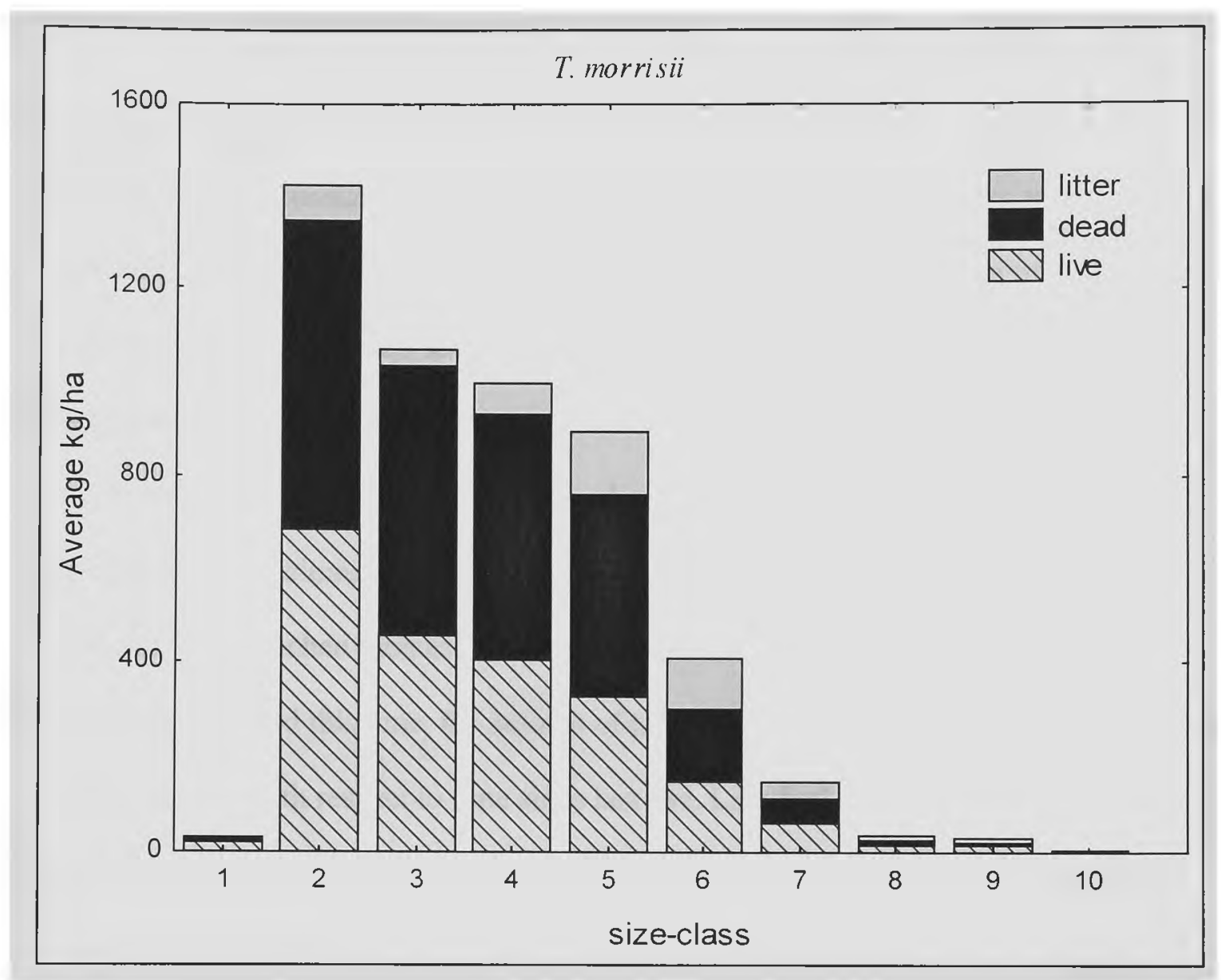

Figure 12. Thrinax morrisii $\mathrm{kg} /$ ha of oven-dried burnable biomass for live, dead attached and litter by size-class (Table 2) in the NKDR of the lower Florida Keys, based on studysites sampled for fuel (Table 1). Kg/ha was obtained by multiplying the average grams/individual for each size-class (Figure 10) of the three biomass components with the average estimated density of $T$. morrisii per hectare by size-class (Table 3 ). 
The total amount of live and dead attached biomass contributed by the two palm species across sites was ranked in order of time since last fire (Figures 13 and 14). Coccothrinax argentata showed no strong pattern when attached biomass accumulations were ranked in order of time since last fire (Figure 13). The large amount of fuel present in the two Poisonwood sites seems to be a result of the high population density of $C$. argentata at these sites, and not highly influenced by the time since last fire.

Thrinax morrisii (Figure 14) however shows a more distinct pattern of live and dead attached burnable biomass accumulation with relationship to time since last fire. Fuel levels for total attached biomass continued to increase for about 4-7 years, and then leveled off. Beyond this time, the amount of total attached fuel fluctuates in an apparently random pattern with respect to time since last fire. Live fuel reached a leveling off point before dead attached fuel did, and live fuel contributed a smaller amount to the total attached fuels. Within the same size-classes $T$. morrisii contributed a larger amount of fuel per individual and also had a higher population density than Coccothrinax argentata, making the amount of fuel contributed by $T$. morrisii greater then that the amount contributed by $C$. argentata. (Note the difference in scale in Figures 13 and 14).

The amount of litter contributed by the two palm species, ranked in order of time since last fire (Figure 15), did indicate a pattern. The relationship seemed to be more obvious for Thrinax morrisii than for Coccothrinax argentata. Litter continued to increase for approximately $11-14$ years. 


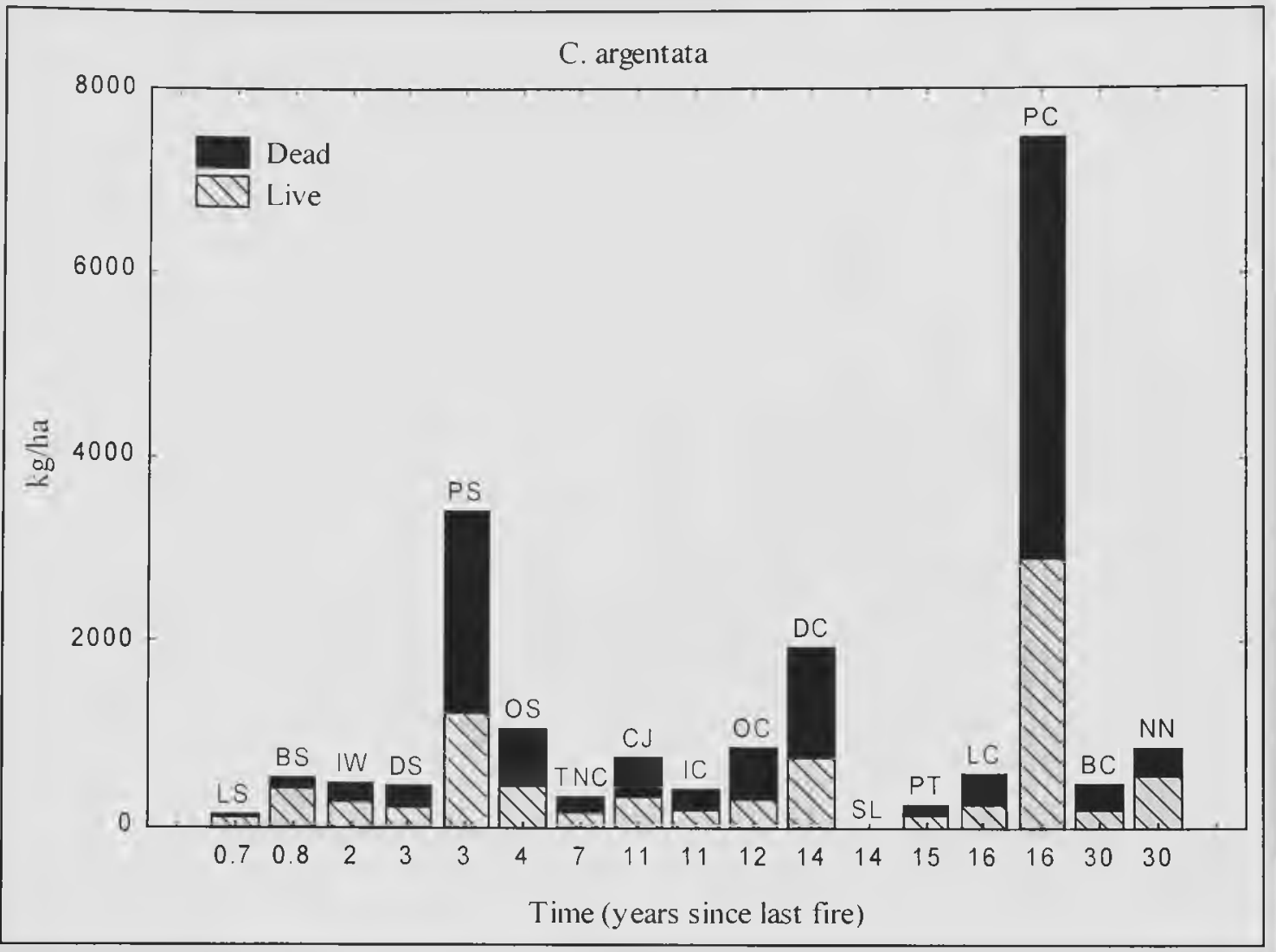

Figure 13. Available total attached Coccothrinax argentata fuel ( $\mathrm{kg} /$ ha dry weight) in the lower Keys study area ranging from 0.7 years to greater than 30 years. Capital letters at top of bars are site name abbreviations. (See table 1 for more detail). Multiplying the average grams contributed by each size-class for each site by the estimated number of individuals per size-class at each site and then summing determined total amount of attached fuel. 


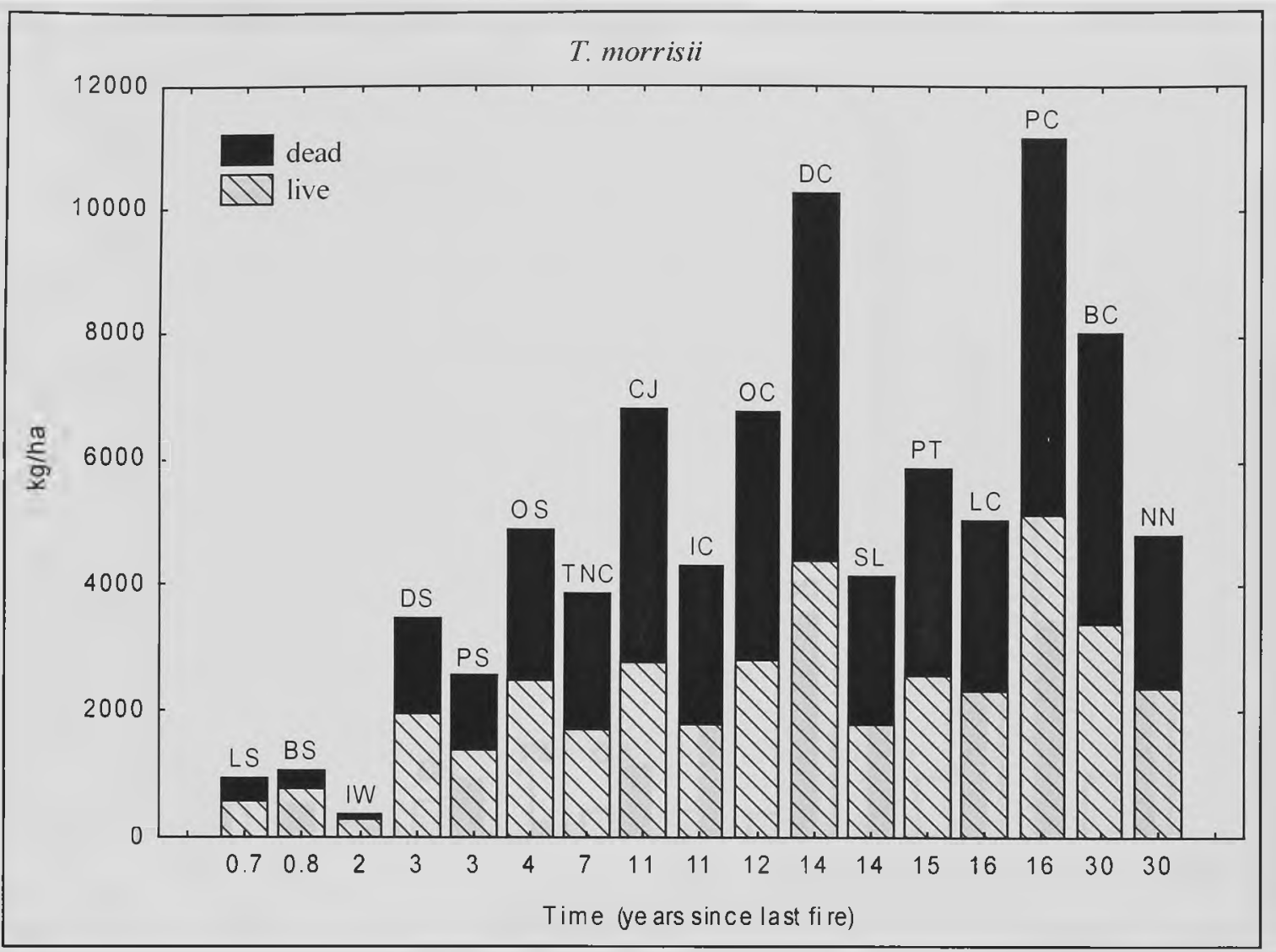

Figure 14. Available total attached Thrinax morrisii fuel (kg/ha dry weight) in the lower Keys study area ranging from 0.7 years to greater than 30 years. Capital letters at top of bars are site name abbreviations. (See table 1 for more detail). Multiplying the average grams contributed by each size-class for each site by the estimated number of individuals per size-class at each site and then summing determined total amount of attached fuel. 


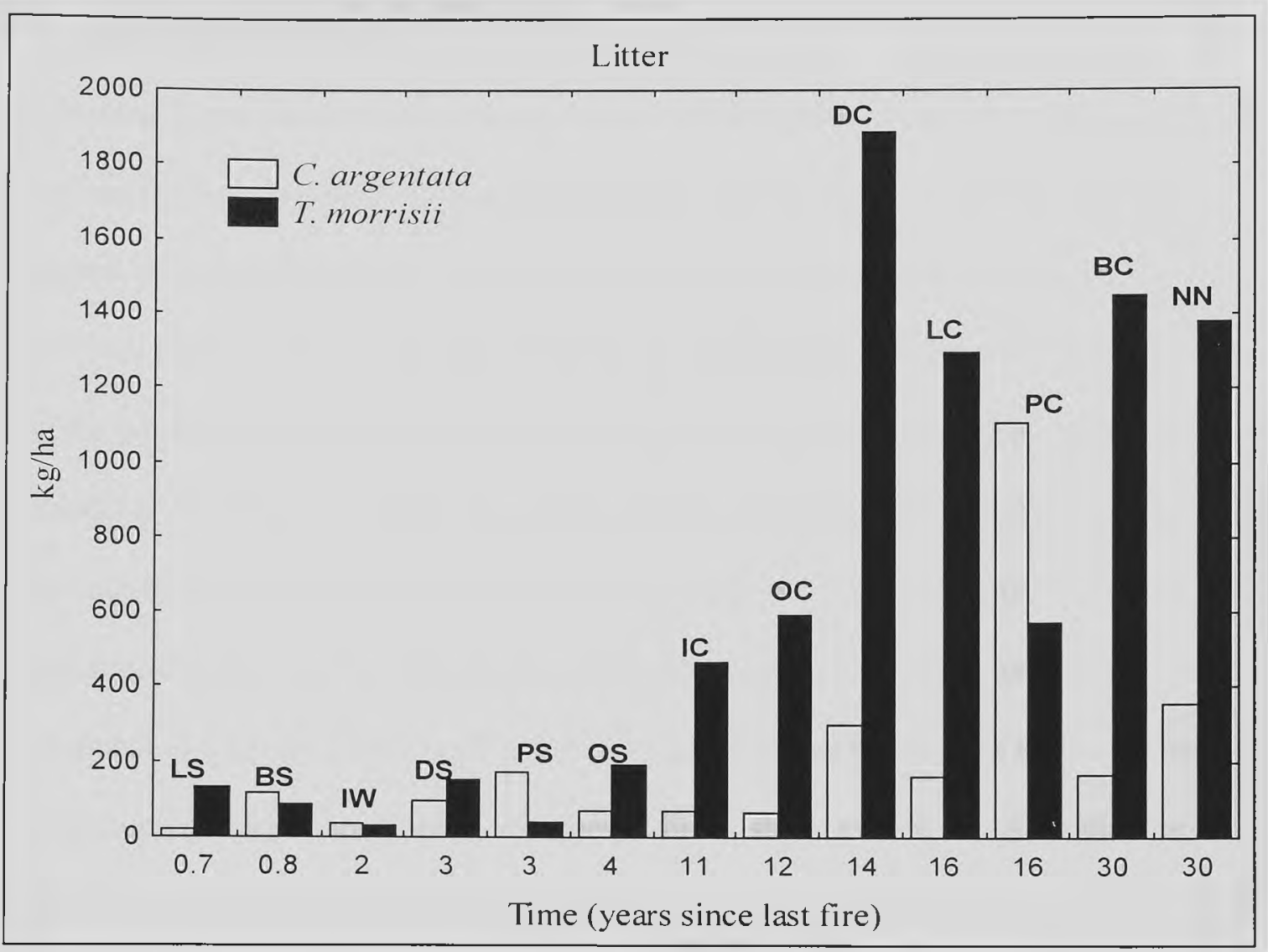

Figure 15. Available litter ( $\mathrm{kg} / \mathrm{ha}$ dry weight) for both palm species ranked in order of time since last fire. Capital letters at top of bars are site name abbreviations. (See table 1 for more detail). Total amount of litter was determined by multiplying the average grams contributed by each size-class for each site by the estimated number of individuals per size-class at each site and then summing. 


\section{Fuel Accumulation Curves}

A relationship between total aboveground burnable biomass and time since last fire is suggested in Figures 13-15. A greater relationship was apparent for Thrinax morrisii attached components and litter than Coccothrinax argentata attached components. However, Figure 7 showed no major trend in the relationship between time since last fire and the population density of palms. It is reasonable to assume that total aboveground burnable palm biomass is highly dependent on palm population density. Additionally, since mortality rates even in burn sites were relatively low (Table 4, Figure 8), the population density may be only slightly affected by time since last fire, and instead may be influenced more by factors such as the cumulative effects of previous fires, or other factors such as micro-topography, soil types, salinity, storm events, etc. Although the influence of the population density is important in the total amount of fuel present at each site, and will be addressed later, the general pattern of fuel accumulation over time on an individual palm provides interesting information.

In order to examine the pattern of palm recovery without the influence of density, I first chose to focus on one size-class from each species (Table 9 and Figure 16). I chose size-class 3 for $C$. argentata and size-class 4 for $T$. morrisii because they were common to almost all sites, contained a large number of individuals per site and the amounts of fuel contributed by each individual in these size-classes were also large enough to see distinct patterns of fuel accumulation. Together, these size-classes were among the largest total contributors to the total palm fuel load (Figures 13-15). 
Table 9. Individual level fuel components (live, dead attached and litter in grams per individual) for Coccothrinax argentata size-class 3 and Thrinax morrisii size-class 4, with sites ranked in order of time since last fire. See Figure 16 for fuel accumulation curves.

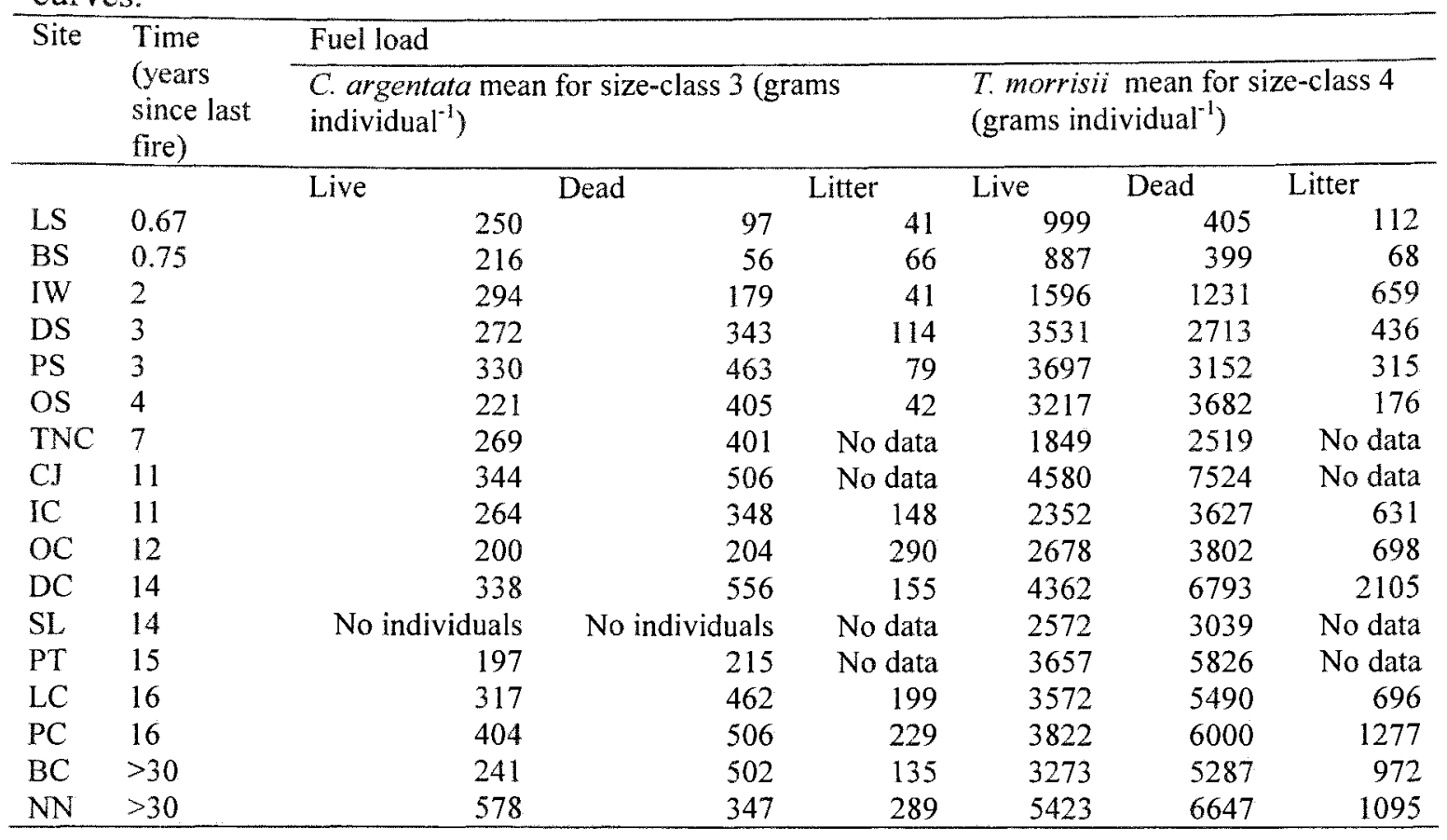


Fuel components (live, dead attached and litter in grams per individual) for Coccothrinax argentata size-class 3 and Thrinax morrisii size-class 4, with sites ranked in order of time since last fire, are shown in Table 9. The amount of fuel for all components increased in relationship to time since last fire. The major component contributing to this pattern was dead attached aboveground burnable biomass. The nonlinear models for these fuel accumulation patterns are displayed in Figure 16a and b, with details provided in Table 11. In general live biomass of both palm species recovered and reached an asymptote faster than dead attached biomass. The amount contributed by litter in both species was lower than either of the attached components (live and dead). Differences in the rates of recovery were observed between $C$. argentata and T. morrisii. C. argentata size-class 3 attached components recovered at a much quicker rate than the attached components of $T$. morrisii size-class 4 . The live biomass for $C$. argentata leveled off in about 2 years while it took closer to 5 years for $T$. morrisii live biomass to level off. Dead attached biomass of both species lagged behind the live attached biomass, reaching an asymptote at around 5 or 6 years for $C$. argentata, but taking closer to $15-20$ years for T. morrisii. Litter levels never accumulated to the amount that the attached components reached, the litter reached an asymptote somewhere around 10 or more years for both species. 

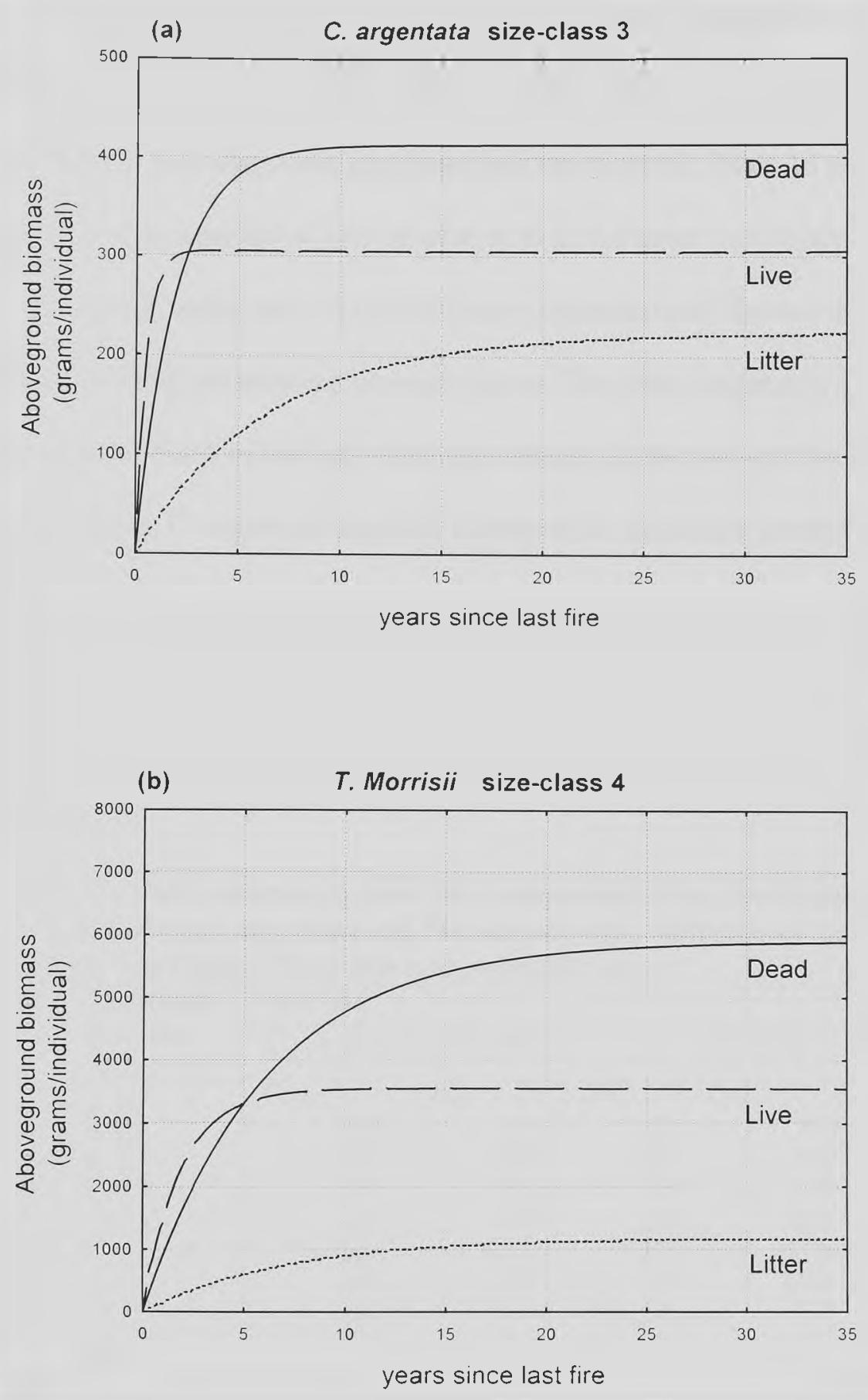

Figure 16. Fuel accumulation curves for: (a) Coccothrinax argentata size-class 3 and (b) Thrinax morrisii size-class 4 for all fuel components in the NKDR of the lower Florida Keys. Stands ranged from less then 1 year of age to over 30 years since time of last fire. Data for curves shown in table 9. Lines show fitted equations, as described in Table 11. 
To estimate the total amount of palm fuel present and to see the pattern of accumulation for all sites, population density of all size-classes and the average amount of fuel per size-class were combined and are shown in Table 10 and Figure 17. The total palm fuel accumulation will be referred to as the palm community level. "Palm community" refers only to Coccothrinax argentata and Thrinax morrisii and does not include Sabal palmetto or Serenoa repens. The palm community level showed similar patterns to those of the individual size-classes for the two species (Table 9 and Figure 16). Again, C. argentata attached components reached an asymptote quicker and at a lower amount than $T$ morrisii. The live component of $\mathrm{C}$. argentata recovered in less then 4 years and the dead attached component in 7 years or less. T. morrisii's live components took approximately 10-15 years to level off and 15-17 years for dead to reach an asymptote.

Table 10. Palm community level fuel components (live, dead attached and litter in $\mathrm{kg} / \mathrm{ha}$ ) for Coccothrinax argentata and Thrinax morrisii, with sites ranked in order of time since last fire. See Figure 17 for fuel accumulation curves.

\begin{tabular}{|c|c|c|c|c|c|c|c|}
\hline \multirow[t]{3}{*}{ Site } & \multirow{2}{*}{$\begin{array}{l}\text { Time (years } \\
\text { since last } \\
\text { fire) }\end{array}$} & \multicolumn{6}{|l|}{ Fuel load } \\
\hline & & \multicolumn{3}{|c|}{ C. argentata total $\left(\mathrm{kg} \mathrm{ha}^{-1}\right)$} & \multicolumn{3}{|c|}{ T. morrisii total $\left(\mathrm{kg} \mathrm{ha}^{-1}\right)$} \\
\hline & & Live & Dead & Litter & Live & Dead & Litter \\
\hline LS & 0.67 & 108 & 32 & 22 & 565 & 365 & 133 \\
\hline BS & 0.75 & 420 & 130 & 119 & 760 & 317 & 89 \\
\hline IW & 2 & 292 & 180 & 34 & 274 & 109 & 30 \\
\hline DS & 3 & 232 & 220 & 98 & 1966 & 1510 & 153 \\
\hline PS & 3 & 1238 & 2175 & 174 & 1376 & 1186 & 38 \\
\hline OS & 4 & 440 & 639 & 72 & 2486 & 2439 & 196 \\
\hline TNC & 7 & 162 & 175 & No data & 1733 & 2146 & No data \\
\hline $\mathrm{CJ}$ & 11 & 345 & 414 & No data & 2784 & 4051 & No data \\
\hline IC & 11 & 188 & 244 & 73 & 1802 & 2531 & 470 \\
\hline $\mathrm{OC}$ & 12 & 319 & 549 & 67 & 2847 & 3961 & 595 \\
\hline DC & 14 & 766 & 1179 & 299 & 4424 & 5872 & 1887 \\
\hline $\mathrm{SL}$ & 14 & 5 & 0 & No data & 1787 & 2386 & No data \\
\hline PT & 15 & 134 & 113 & No data & 2595 & 3308 & No data \\
\hline $\mathrm{LC}$ & 16 & 261 & 331 & 161 & 2327 & 2736 & 1300 \\
\hline $\mathrm{PC}$ & 16 & 2916 & 456 & 1108 & 5146 & 6041 & 577 \\
\hline $\mathrm{BC}$ & $>30$ & 204 & 279 & 169 & 3405 & 4655 & 1451 \\
\hline $\mathrm{NN}$ & $>30$ & 576 & 300 & 357 & 2366 & 2464 & 1379 \\
\hline
\end{tabular}



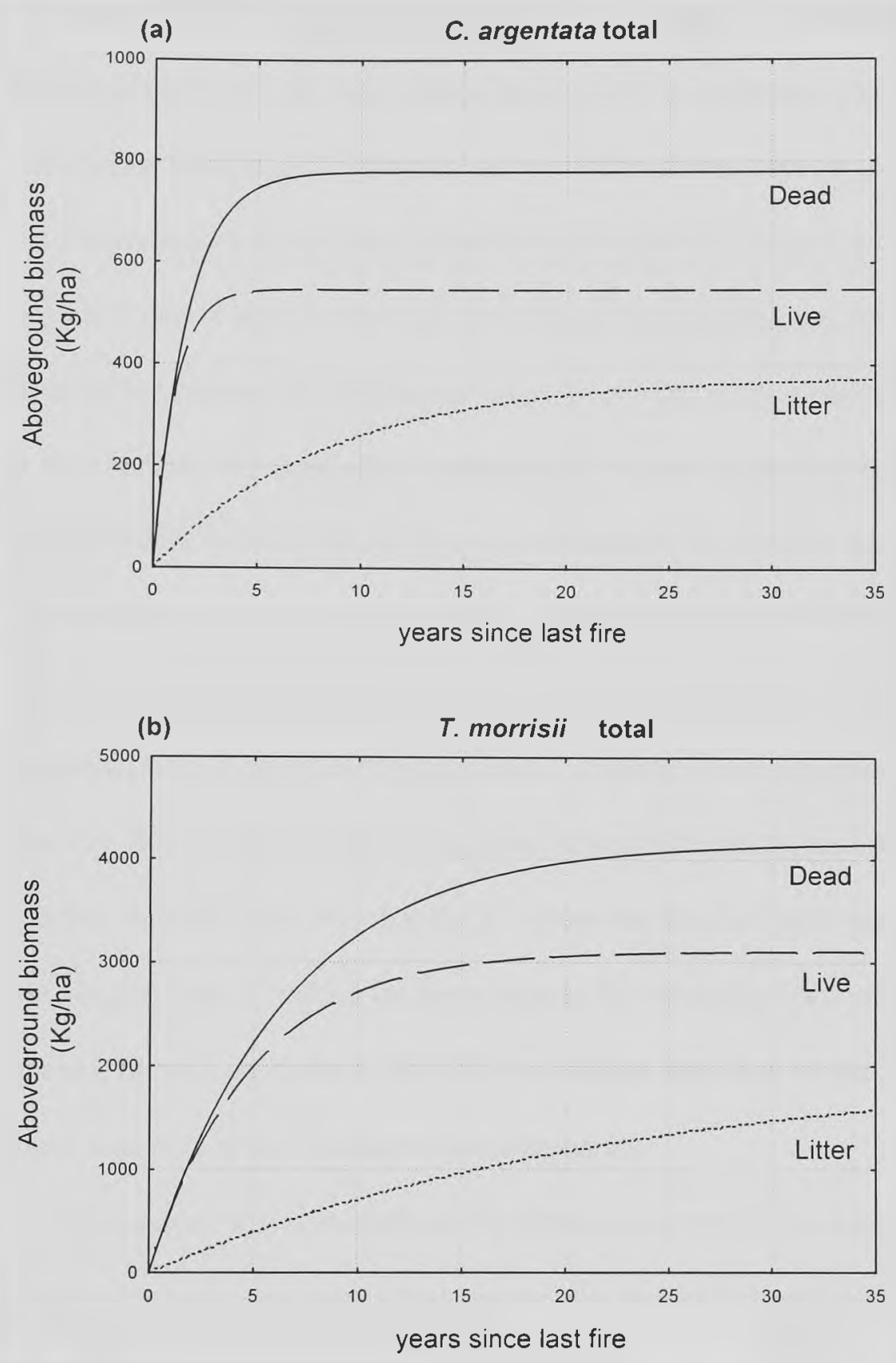

Figure 17. Fuel accumulation curves for: (a) Coccothrinax argentata palm community level and (b) Thrinax morrisii palm community level 4 for all fuel components in the NKDR of the lower Florida Keys. Stands ranged from less then 1 year of age to over 30 years since time of last fire. Data for curves shown in table 10. Lines show fitted equations, as described in Table 11. 
Parameter estimates and standard errors for equations fitted to the fuel loading are shown in Table 11. $\mathrm{R}^{2}$ values range from 0.02 (Coccothrinax argentata live at the palm community level) to 0.71 (Thrinax morrisii litter at the palm community level). $\mathrm{R}^{2}$ values for the models I used did not always fit the fuel accumulation curve well. However my objective was to take the data for the different components and apply the same equation in order to compare the responses of the curves. The relative strength of the relationship is information. For example, $C$. argentata $\mathrm{R}^{2}$ values for the attached components at both the individual size-classes and the palm community level were much lower than the values for the attached components of $T$. morrisii. Finding that there is less of a relationship between time since last fire and the amount of fuel contributed by $C$. argentata than $T$. morrisii suggests that $C$. argentata recovers more quickly after fire, and also that fuel levels fluctuate to a greater degree after the asymomtote is reached in theses species. Another trend was that the $\mathrm{R}^{2}$ values for attached dead material for both species were higher than $\mathrm{R}^{2}$ values for live material. $\mathrm{R}^{2}$ values for litter were similar for both species. In most cases the $\mathrm{R}^{2}$ for litter was higher than that for the live component but lower than that of the dead attached component.

The amount of fuel contributed by Thrinax morrisii to the ecosystem at the palm community level was greater than the amount of fuel Coccothrinax argentata contributed. Both species followed a similar pattern in which live fuel recovered quickly and leveled off before dead attached fuel did, however the amount of fuel at which the attached fuels asymptote was greatly different. The greatest amount of fuel contributed by both species was dead attached, however the level at which dead attached reaches an 
asymptote, for the palm community level, is less than $800 \mathrm{~kg} /$ ha for C. argentata and over $4,000 \mathrm{~kg} /$ ha for $T$. morrisii.

Table 11. Estimated values for parameters in fuel accumulation models for live, attached dead, and litter in the pine forests of the lower Florida Keys. Fuel accumulation is modeled by the equation $\mathrm{X}_{\mathrm{t}}=\mathrm{X}_{\mathrm{ss}}\left(1-\mathrm{e}^{-\mathrm{ktime}}\right)$ also written for analyses as $\mathrm{X}_{\mathrm{t}}=\mathrm{b} 0-\mathrm{b} 0 * 0^{*} \exp \left(-\mathrm{b} 1^{*}\right.$ time $)$

$X_{s s}=(b 0), k=b$ l, where $X_{t}$ is the weight of fuel accumulated at a given time since last fire, $X_{s s}$ and $b 0$ the weight of fuel under steady-state conditions, and $\mathrm{k}$ or bl the decomposition constant (McCaw et al. 2002). Note: Time refers to years since last fire.

\begin{tabular}{|c|c|c|c|c|c|}
\hline \multirow[t]{2}{*}{ Fuel component } & \multicolumn{5}{|c|}{$\begin{array}{l}\text { Parameter } \\
\mathrm{X}_{\mathrm{ss}}\left(\mathrm{g} \text { ind. }{ }^{-1}\right) \text { or }\left(\mathrm{Kg} \mathrm{ha}^{-1}\right)\end{array}$} \\
\hline & Estimate(b0) & Std. error & Estimate(b1) & Std. error & $\mathrm{R}^{2}$ \\
\hline \multicolumn{6}{|c|}{ C. argentata(size-class $3 \mathrm{~g} /$ individual) } \\
\hline LIVE & 305.47 & 25.87 & 2.022 & 1.36 & $\overline{0.06}$ \\
\hline DEAD & 413.32 & 36.17 & 0.522 & 0.21 & 0.52 \\
\hline LITTER & 223.49 & 34.76 & 0.16 & 0.07 & 0.65 \\
\hline \multicolumn{6}{|c|}{ T. morrisii (size-class $4 \mathrm{~g} /$ individual) } \\
\hline LIVE & 3545.78 & 285.62 & 0.538 & 0.22 & 0.48 \\
\hline DEAD & 5910.71 & 710.64 & 0.164 & 0.06 & 0.70 \\
\hline LITTER & 1175.01 & 274.54 & 0.145 & 0.10 & 0.52 \\
\hline \multicolumn{6}{|c|}{ C. $\operatorname{argentata}($ Total $\mathrm{kg} / \mathrm{ha})$} \\
\hline LIVE & 548.01 & 198.23 & 0.987 & 2.27 & 0.02 \\
\hline DEAD & 780.18 & 344.15 & 0.632 & 1.48 & 0.04 \\
\hline LITTER & 378.42 & 223.02 & 0.117 & 0.18 & 0.20 \\
\hline \multicolumn{6}{|c|}{ T. morrisii (Total $\mathrm{kg} / \mathrm{ha})$} \\
\hline LIVE & 3113.06 & 423.90 & 0.206 & 0.10 & 0.52 \\
\hline DEAD & 4167.58 & 690.60 & 0.153 & 0.07 & 0.63 \\
\hline LITTER & 2010.96 & 1153.21 & 0.044 & 0.04 & 0.71 \\
\hline
\end{tabular}

\section{Leaf Moisture Content}

The fuel moisture content for both palm species for live and dead leaf blades and petiole tissues are presented in Table 12. For both species, the moisture content of attached dead leaves was significantly lower then that of the live attached leaf material. Moisture retention was higher in the petioles than leaf blades, regardless of species. The moisture content of litter was slightly less than that of the attached dead leaves. 
Table 12. Moisture Content of live and dead attached leaves and litter. (Fresh wt-Dry wt)/Dry wt $x 100$ $\mathrm{n}=3$ for Coccothrinax argentata live and dead and Thrinax morrisii live, $\mathrm{n}=4$ for $T$. morrisii dead Each $\mathrm{n}$ for live and dead, leaf and petiole for both species is average of 5 leaves, collected at 3 different study sites. $n=13$ for both species of litter is an average of litter collected over 13 different days. This was the same loose palm litter collected in the field in order to estimate percent dry weight. (Refer to page 20).

\begin{tabular}{lllr}
\hline Type & C. argentata & T. morrisii \\
& $\%$ Moisture (standard deviation) & \%Moisture (standard deviation) & \\
\hline Live-leaf & $79(3)$ & $87(1)$ \\
Live-petiole & $135(6)$ & $125(11)$ \\
Dead-leaf & $14(1)$ & $27(19)$ \\
Dead-petiole & $28(15)$ & $59(55)$ \\
Litter & $9(3)$ & $10(3)$ \\
\hline
\end{tabular}

\section{DISCUSSION}

\section{Population Size Structure and Biomass Accumulation}

Total palm fuel in this forest is the product of two components: the density of palms in the community, and the amounts of fuel present on individual palms. The relationships between palm population density and time since last fire are weak in this study, while the relationships between the amount of fuel an individual palm contributes and time since last fire are stronger. When these two components are combined, a moderately strong relationship between time since last fire and palm fuel is observed. The general pattern is one of increasing fuel with age, until equilibrium is established between fuel deposition and decomposition rates, and the fuel load stabilizes (McCaw et al. 2002, Chaffey and Grant 2000, Wirth et al. 1999).

Based on data collected by the FIU/USGS study, the total amount of fuel present in pre-burn sites in the lower Florida Keys pine rocklands was $175,000 \mathrm{~kg} / \mathrm{ha}$ of which $9,000 \mathrm{~kg} / \mathrm{ha}$ was contributed by the shrub layer. Coccothrinax argentata and Thrinax morrisii comprise a large portion of understory shrub layer density in the study area, $15 \%$ 
and $27 \%$, respectively. The shrub layer, in this study and the FIU/USGS study, includes all vegetation over 1 meter in total height, but is limited to the pines and hardwoods having a DBH (Diameter at Breast Height) of less than $5 \mathrm{~cm}$. Pines and hardwoods having a DBH greater than $5 \mathrm{~cm}$ are included in the canopy layer. Within the $9,000 \mathrm{~kg} / \mathrm{ha}$ of total shrub layer fuel, palms contribute $55 \%(4,900 \mathrm{~kg} / \mathrm{ha})$, hardwoods $35 \%(3,200$ $\mathrm{kg} / \mathrm{ha}$ ) and pines $10 \%(780 \mathrm{~kg} / \mathrm{ha})$. This estimate may include a few palms that exceed the average height of the pines and hardwoods at $5 \mathrm{~cm} \mathrm{DBH}$ (approximately 4.5-5.0 meters) on Big Pine. However, the percentage of C. argentata and T. morrisii over 4.5 meters in this study are low, at $0 \%$ and $0.25 \%$, respectively.

Differences in the total abundance of the two palm species in the study area (Appendix A) may be due to environmental conditions and past natural and anthropogenic events, as there is little or no observable trend in palm density or size distribution with time since last fire (Figure 7). On average, Thrinax morrisii is slightly more abundant $(\sim 10,000$ individuals/ha) than Coccothrinax argentata $(\sim 8,170$ individuals/ha). In their study of two similar palms (Coccothrinax readii Quero and Thrinax radiata Lodd. ex J.A. Schult.) in the dry tropical forest in Quintana Roo, Mexico, Olmsted and Alvarez-Buylla (1995) also found that individuals of the genus Thrinax were more abundant than those of the genus Coccothrinax. Likewise, I also observed differences in the size-class distribution of the two species (Table 3). C. argentata is not represented in the two largest size-classes, indicating that $T$. morrisii obtained a larger size in my study area. The greater abundance and larger size of $T$. morrisii combine to make a larger contribution to the total shrub biomass in comparison to $C$. argentata. When comparing the amount an average individual, $T$. morrisii produced and retained a 
greater amount of biomass than an average $C$. argentata in the same size-class (Figure 9 and 10). T. morrisii therefore contributes a much larger amount of burnable biomass to the stand total. This will be discussed in greater detail below.

At all 17 study sites, the vast majority of individuals of both species are in the nonreproductive size-classes 1 and $2(94 \%)$. The mean density of the Coccothrinax argentata, in size-classes 1 and 2 is 7,720 individuals/ha compared to 450 individuals/ha in classes 3-8. For Thrinax morrisii, these mean densities are 9,420 and 590 individuals/ha, respectively. These are typical examples of L-shaped frequency distributions, with many individuals in the smaller size-classes and few in the large sizeclasses (Barbour et al. 1999, Silvertown and Charlesworth 2001, Ogawa and Hagihara 2003). Mortality and birth rates can be interpreted from such a distribution, if seedling input is constant and if size-class can be equated with age (Ross et al. 1982). However, it is uncertain if those assumptions hold here. The effect of fires on palm mortality will be discussed in greater detail in a later section.

\section{Regression Analysis}

Multiple regression analysis shows that the natural log of crown area plus number of leaves provided the best predictors for total attached, live, and dead attached biomass (Table 7 and Appendices $C$ and D). This is based on the maximum $R^{2}$ and the minimum absolute percent deviation (Table 7 and Appendices C and D). Natural log of area and number of attached leaves alone are fair predictors of biomass, with number of leaves being the better of the two, however the combination of the two is best. Between these two variables, the number of leaves, particularly dead attached leaves of Thrinax 
morrisii, seems to vary more in relationship to time since last fire than does crown area.

Neither height of tallest leaf or apical stem height are good predictors of attached biomass.

\section{Mortality}

Despite the weak relationship between time since last fire and the population density of palms (Figure 8), my observation of greater mortality in the burned than unburned plots suggests that fire does have a role in palm population structure. The low background mortality rates of Coccothrinax argentata and Thrinax morrisii in the control plots are consistent with the findings of Abrahamson (1995) for other palm species. He found that background mortality of Serenoa repens and Sabal etonia growing in flatwoods and scrubby flatwoods in the Lake Wales region of central Florida was very low; none of the 240 palmettos tagged for observation, died during the 15 -year study period. Additional studies by Abrahmson (1995) showed that out of 8,000 individual palmettos monitored for periods ranging from 4-15 years, only two deaths occurred and one was human caused. Thus, with very low background mortality, even the moderate mortality rates I observed for a single fire event, i.e. $13.2 \%$ in $C$. argentata and $7.8 \%$ in T. morrisii, suggest that the cumulative effects of multiple fire events shape the palm community structure, if not overall density.

Within the burn plots, I observed a higher amount of palm mortality in the larger sizeclasses. By removing the largest individuals, this mortality pattern contributes to the size structure described above, in which small individuals are numerically dominant. This mortality pattern therefore differs from the results of McPherson and Williams(1998), 
for Sabal palmetto in central Florida, and Silva Matos et al.(1999) for Euterpe edulis

Mart. in Brazil, where the highest mortality occurred in the smallest palm size-classes.

The Brazil site was not a fire prone area and the results of the low mortality in the larger size-classes may be further support for low background mortality rates in palms. Sizedependent mortality could have other consequences at the population and ecosystem levels. For instance, if seed production is also highest among the largest individuals, as it usually is (Greene and Johnson 1994, Leimu and Syrjanen 2002), then elevated mortality among this group may reduce the reproductive potential of the population. At the same time, periodic disturbances, such as fire, that kill large individuals create opportunities for small individuals to grow into the next size-class. Of special pertinence here is that the mortality of larger palms has a greater impact on the total fuel load than does the mortality of smaller palms. In general, given the "youthful" size structure distribution and the moderate level of mortality caused by a single fire event, it seems that $C$. argentata and T. morrisii are well adapted to fire, and their populations show no evidence of being adversely affected by the prescription fires I monitored. However, a longer-term study that includes multiple fires is needed to provide more information about the cumulative effects of fire on the population structure.

\section{Growth and Age Estimate}

This study found that, compared to the burned plots, more palms in the control plots showed measurable height increase. This could mean that fire has a short-term, inhibitory effect on growth rate. The slower height increase in the burned sites seems to contradict 
the rapid recovery of live biomass. Fire could be one of the factors contributing to sporadic growth in these species.

In the lower Florida Keys, my data indicate that $C$. argentata becomes reproductively mature when apical stem height is between 0.2 and 0.5 meters. With a maximum growth rate of $0.025 \mathrm{~cm} / \mathrm{year}$, an estimate for the minimum age of reproduction is between 8 and 20 years. For T. morrisii, reproductive status is reached between an apical stem height of 0.51 and 1.5 meters. Using the growth estimate from this study of $0.05 \mathrm{~cm} /$ year, the age at which reproductive status is reached is between 10 and 30 years. These must be considered minimum estimates that are probably rarely if ever achieved, because they do not account for a possible establishment phase (time in which the stem grows downward, before growing upward) (McPherson and Williams 1996) and assume maximum growth is achieved in every year of stem development.

A longer period of monitoring, perhaps ten or more years, may be necessary to predict better the average growth rate of the palms in this study. The slow, sporadic and localized nature of palm growth (Zona 2000) makes it difficult to measure accurately in only a two-year study. Also, further study should be done in order to determine if an establishment phase is present in C. argentata or T. morrisii. McPherson and Williams (1996) found that in S. palmetto, there was an establishment phase of 30-60 years. The establishment phase of $C$. argentata and $T$ morrisii has not been studied. However Tomlinson (2001) indicated that all palms show some degree of establishment growth.

Coupled with low mortality rates, the estimated slow growth rates, especially in control sites, suggests that $C$. argentata and T. morrisii in the lower Keys are long-lived and have a low turnover rate. My minimum estimates for the age of the largest palms 
observed are between 84-136 years. Abrahamson (1995) found that Sabal etonia and Serenoa repens populations in the Lake Wales region of central Florida were possibly centuries old. The data for this study suggest that the palms in the lower Keys pine forests may not survive for multiple centuries, but could exceed 100 years. In the dry tropical forest of Quintana Roo, Mexico, Olmsted and Alvarez-Buylla (1995) estimated the maximum life span of Thrinax radiata to be between 100-145 years old and Coccothrinax readii to be greater than 145 years.

\section{Fuel Recovery Time}

Both at the individual and palm community levels, Coccothrinax argentata recovered live and dead attached biomass after fire at a quicker rate than did Thrinax morrisii (Figures 16 and 17). However, T. morrisii contributed a larger amount of biomass. Following a fire, live biomass for individual C. argentata returned to pre-burn levels in 24 years (Figure 16a). In contrast, individuals of T. morrisii (Figure 16b) took about 5 years to reach pre-burn levels for live biomass. The recovery of dead attached biomass is not far behind that of live biomass in C. argentata individuals, taking between 5-7 years to reach pre-burn levels. The recovery of $T$. morrisii individual dead attached biomass took between 15-17 years. At the palm community level (Figure 17), C. argentata closely paralleled the pattern and time frame that the individual $C$. argentata demonstrated. $T$. morrisii at the palm community level, however, is much slower to reach equilibrium than are individual $T$. morrisii. At the palm community level, $T$. morrisii live biomass took 5 10 years to reach equilibrium and 12-20 years for dead biomass to reach equilibrium. Snyder (1986) found that in Everglades National Park, Sabal palmetto and Serenoa 
repens recovered live biomass within 1 year after fire. Greenberg (2003) found that in central Florida, Sabal etonia regained its pre-burn cover and height within 5 months. The recovery of $C$. argentata and $T$. morrisii live biomass in the lower Keys is slower than that of Everglades and central Florida palms, however it is still rapid compared to many ecosystems that take decades or centuries to recovery. Litter levels at the base of the stem of both species at the individual and palm community levels are less than attached fuels and accumulated at a slower rate, taking between 10 to 20 years to reach equilibrium (Figures 16 and 17).

Note that the $\mathrm{R}^{2}$ values for Coccothrinax argentata in both the size-class 3 and at the palm community level are very low, 0.06 and 0.002 , respectively, and that the $\mathrm{R}^{2}$ of $C$. argentata dead attached at the palm community level is 0.04 and litter is 0.20 (Table 11). The $\mathrm{R}^{2}$ values for the attached components of $T$. morrisii and litter are higher ranging, at 0.48-0.71 (Table 11). Caution should be taken when interpreting live C. argentata curves. However, I believe the poor fit is a result of a great variation in the amount of biomass retained by $C$. argentata once the leveling off stage has been reached, and that recovery time estimates are still reasonable.

The rapid recovery of attached palm biomass after fire indicates not only that these species are well adapted to fire, but also that they may have an immediate influence on the likelihood and intensity of the next fire occurring. Dead attached palm biomass contributes more to the total fuel load than does either live biomass or litter. The dead attached leaves also have a lower moisture content than does the live (Table 12). It is the retention of the dead material with lower moisture content that is an important factor in 
determining whether a fire occurs or how rapidly it spreads, because it is the dead fuel that initially carries the fire (Bond and van Wilgen 1996).

Hierro and Menges (2002) found that in the pine flatwoods of south-central Florida, added fuel created significantly more intense fires. Maximum air and soil temperatures during the burn were positively correlated with the amount of fuel present at the time of ignition. Nevertheless, higher temperatures caused only a short-term delay in the resprouting of Sabal etonia and Serenoa repens, and overall there were no long-term effects of additional fuels on the density or species richness of pine flatwood shrubs. Baeza et al. (2002) found that in Mediterranean gorse shrublands, fire behavior differed with fuel loads, and the rate of fire spread was related to stage of stand development. Greater fire spread was correlated with lower fuel moisture, and more mature stands had decreased moisture content due to the accumulation of dead fuels and the low moisture content of some of the live fuels associated with late-succesional shrubland species.

The ratio of live to attached dead biomass for Coccothrinax argentata (Figure 13) did not differ noticeably with time since last fire. However the ratio of live to attached dead biomass did decrease with time since fire in Thrinax morrisii (Figure 14), suggesting that leaves of this species may have a longer retention time than those of its palm associate. In my regression models, it took 4-7 years for the amount of dead attached T. morrisii biomass to exceed the amount of live biomass (Figures $16 \mathrm{~b}$ and 17b).

Mutch (1970) hypothesized that plants that evolved to survive in fire prone habitats may also inherit flammable properties, such as the retention of dead material, that contribute to the perpetuation of fire-dependent plant communities. Pine forests, in general, are known to be highly flammable and burn frequently (Mutch 1970, Hierro and 
Menges 2002, Stephens and Finney 2002). Needles of pine trees provide readily ignited fuels (Bond and van Wilgen 1996), and their thick bark protects the cambium from fire related mortality (Spalt and Reifsnyder 1962, cited by Whelan 1995). The pine rocklands of the Florida Keys have a monotypic canopy of slash pine, and the two dominant shrubs in the understory, Coccothrinax argentata and Thrinax morrisii, rapidly accumulate and retain fuel, particularly dead fuel. Based on this rapid recovery and retention of fuel, particularly of the dead fuel with a lower moisture content and higher probability of ignition, there may be sufficient fuel to support a fire frequency in the range of 5-10 years in the pine forests of the lower Keys.

Mutch's hypothesis has received criticism. One argument is that flammability is a secondary result of selection for other traits (Snyder 1984). For instance, the same traits that make a leaf less attractive to herbivores, such as high cellulose or high wax content, make a leaf more flammable (Rundel 1981, cited in Bond 1996). However, Mutch's hypothesis could be applied to palms, since my work shows that palms retain dead leaves, a characteristic that results in an increase in flammability, which could enhance fitness in a species adapted to survive fire and reproduce afterward.

The pine rocklands of Everglades National Park are estimated to burn at frequencies of once every 3-7 years (Snyder 1986). This range was inferred from the upper (10-15 years) and lower (2-3 years) limits of fire frequency: the upper limit based on the time it takes for the endemic herbaceous plants to be shaded out by the shrubby vegetation, and the lower limit on the time it takes for sufficient fuel to accumulate. Less is known about the estimated fire frequency of the pine rocklands of the lower Florida Keys. The asymptote of dead attached palm fuel recovery for Thrinax morrisii, estimated by this 
study to be approximately 10 years, is an estimate close to the upper fire frequency limit in the Everglades pine rocklands.

Given the assumptions based on my results; that palm fuel levels accumulate at a rapid enough rate to support the occurrence of a fire every 5-10 years, and the maximum age range of palms is a minimum of 84-136 years, then an individual palm that lives out its full life span would encounter between 8-27 fires. With the mortality rates from a single fire event ranging from $6 \%$ to $18 \%$, cumulative fire events must shape the size structure. Moreover, the higher frequency of mortality in the larger reproductive size classes indicates that as palms age and grow, contributing more fuel, there is a greater likelihood that they will be killed in a fire.

\section{Management Implications}

Three factors are needed for a fire to occur: an ignition source, low humidity, and fuel. All of these factors are important and are interlinked. The frequency of potential ignition sources, mostly lightning, and the prevailing weather conditions determine the likelihood of fire starting. However, the intensity of fire is generally determined by the quantity of fuel available and the rate at which it combusts (Chaffey and Grant 2000). Only the fuel loads and vegetation structure can be directly manipulated by humans to influence the fire regime, and this is the rationale for many controlled fires (Chaffey and Grant 2000, Fernandes and Botelho 2003). Of course, fuel reduction alone is not going to end all catastrophic fires; the issue is more complicated than that. However, fuel accumulation should be a fundamental concern for wildland managers in developing a prescribed fire plan. Burning must be frequent enough to maintain fuel loads at levels 
below which they would support an uncontrollable fire. In an ecosystem with high productivity of dead material, frequent burning may be necessary in order to keep dead fuels at a low level. The data from this study indicates that after burning, the fuel loads contributed by Coccothrinax argentata, and more importantly by Thrinax morrisii, will usually return to pre-burn levels in 5-10 years. If palm fuel reduction is a goal then, consideration should be given to a fire management plan that that introduces a burn frequency within this range of 5-10 years to keep fuel levels below the maximum level or at that level for as short a period as possible. This will decrease the likelihood that a heavy palm fuel load will lead to a high-intensity fire and serious damage to wildlife and or property. However, Pyne (1989) examined the Yellowstone fires of 1988 and found that low-intensity fires with the intent of fuel reduction did not remove enough dead material, and that occasional higher intensity fires were necessary. Intentional higher intensity fires in the lower Keys would be difficult due to the intermix of pine forests with suburban and commercial structures. The cumulative mortality of larger palms at a 5-10 year fire frequency is also unknown and may warrant further study.

The information provided by this study, combined with additional information from the FIU/USGS studies and the associated study of Liu (2003), should help wildland managers in the NKDR better understand the rate and manner at which burnable fuels accumulate and the role fire plays in the reduction of fuels and the effects of fire on endemic species. Other studies and criteria also need to be considered in development of a burn plan, such as the entire ecosystem health, the effect of fire on wildlife, and how rare and endemic plants react to prescribed fire frequency. Recreational and residential concerns of the urban interface area also need to be considered. 
Abrahamson, W.G. 1984. Species response to fire on the Florida Lake Wales Ridge. American Journal of Botany 71:35-43.

Abrahamson, W.G. 1995. Habitat distribution and competitive neighborhoods of two Florida palmettos. Bulletin of the Torrey Botanical Club 122(1):1-14.

Abrahamson, W.G. 1999. Episodic reproduction in two fire-prone palms, Serenoa repens and Sabal etonia (Palmae). Ecology 80(1):100-115.

Alexander, T.R. and J.D. Dixion III. 1972. Vegetational changes in the National Key Deer Refuge II. Quarterly Journal of the Florida Academy of Sciences 35:85-96.

Baeza, M.J., M. De Luís, J. Raventós and A. Escarré. 2002. Factors influencing fire behavior in shrublands of different stand ages and the implications for using prescribed burning to reduce wildfire risk. Journal of Environmental Management 65:199-208.

Barbour, M.G., J.H. Burk, W.D. Pitts, F.S. Gilliam, and M.W. Schwartz. 1999. Terrestrial Plant Ecology. Addison Wesley Longman, Inc. Menlo Park, California, USA.

Baskerville, G.L. 1971. Use of logarithmic regression in the estimation of plant biomass Canadian Journal of Forest Research 2:49-53.

Beauchamp, J.J. and J.S. Olson. 1973. Correction for bias in regression estimates after logarithmic transformation. Ecology 54(6):1403-1407.

Bergh, C. and J. Wisby. 1996. Fire history of the lower Keys pine rockland. The Nature Conservancy unpublished document. Key West, FL. 23pp.

Bessie, W.C. and E.A. Johnson. 1995. The relative importance of fuels and weather on fire behavior in subalpine forests. Ecology 76(3):747-762.

Bond, W.J. and B.W. van Wilgen. 1996. Fire and Plants. Chapman and Hall, London, U.K.

Brown, R. B., Stone, E. L. and V. W. Carlisle. 1990. Soils. Pages 35-69 in R.L. Myers and J.J. Ewel, editors. Ecosystems of Florida. University of Central Florida Press, Orlando, Florida, USA. 
Chaffey, C.J. and C.D. Grant. 2000. Fire management implications of fuel loads and vegetation structure in rehabilitated sand mines near Newcastle, Australia. Forest Ecology and Management 129: 269-278.

Coile, N.C. 1998. Notes on Florida's endangered and threatened plants. Division of Plant Industry, Florida Department of Agriculture and Consumer Services. Gainesville, Florida, USA. 119pp.

Coniglio, M. and R.S. Harrison. 1983. Facies and diagenesis of Late Pleistocene carbonates from Big Pine Key, Florida. Bulletin of Canadian Petroleum Geology $31(3): 135-147$.

Fernandes, P.M. and H.S. Botelho. 2003. A review of prescribed burning effectiveness in fire hazard reduction. International Journal of Wildland Fire 12:117-128.

Finney, D.I. 1941. On the distribution of a variate whose logarithm is normally distributed. Journal of the Royal Statistical Society Series B 7:155-161.

Garren, K.H. 1943. Effects of fire on vegetation of the Southeastern United States. Botanical Review 9:617-654.

Greenberg, C.H. 2003. Vegetation recovery and stand structure following a prescribed stand-replacement burn in Sand Pine Scrub. Natural Areas Journal 23:141-151.

Greene, D.F. and E.A. Johnson. 1994. Estimating the mean annual seed production of trees. Ecology 75(3):642-647.

Gunderson, L., D. Taylor, and J. Craig. 1983. Fire Effects on Flowering and Fruiting Patterns of Understory Plants in Pinelands of Everglades National Park. Technical Report SFRC-83/04. Everglades National Park, South Florida Research Center, Homestead, Florida USA.

Harper, J.L. 1977. Population Biology of Plants. Academic Press, London, U.K.

Henderson, A., G.Galeano, and R. Bernal. 1995. Field Guide to the Palms of the Americas. Princeton University Press, Princeton, New Jersey, USA.

Hierro, J.L. and E. S. Menges. 2002. Fire intensity and shrub regeneration in palmettodominated flatwoods of central Florida. Florida Scientist 65(1):51-61

Klimstra, W.D., J.W. Hardin, N.J. Silvy, B. N. Jacobson, and V.A. Terpening. 1974. Key deer investigations final report. Period of study: December 1967-June 1973. Cooperative Wildland Research Lab., Southern Illinois University, Carbondale, MN. $184 \mathrm{pp}$. 
Klimstra, W.D. and A.L. Dooley. 1990. Foods of the Key deer. Biological Sciences 4: 264-273.

Leimu, R. and K. Syrjanen. 2002. Effects of population size, seed predation and plant size on male and female reproductive success in Vincetoxicum hirundinaria (Asclepiadaceae). Oikos 98(2):229-238.

Liu, H. 2003. Population viability analyses of Chamaecrista keyensis (Leguminosae: Caesalpinioideae), a narrowly endemic herb of the lower Florida Keys: Effects of seasonal timing of fires and urban-wildland interface. Doctoral Dissertation, Miami, Florida: Florida International University.

McCaw, W.L. and J.E. Neal, and R.H. Smith. 2002. Stand characteristics and fuel accumulation in a sequence of even-aged Karri (Eucalyptus diversicolor) stands in south-west Western Australia. Forest Ecology and Management 158:263-271.

McPerson, K. and K. Williams. 1996. Establishment growth of Cabbage palm, Sabal palmetto (Arecaceae). American Journal of Botany. 83 (12):1566-1570.

McPherson, K. and K. Williams. 1998. Fire resistance of Cabbage Palms (Sabal palmetto) in the Southeastern USA. Forest Ecology and Management 109:197-207.

Mutch, R.W. 1970. Widland Fires and ecosystem-A hypothesis. Ecology 51(6):10461051.

Nauman, C.E. 1990. Intergeneric Hybridization between Coccothrinax and Thrinax (Palmae: Coryphoideae). Principes 34(4):191-198.

National Weather Service-National Hurricane Center. Tropical Prediction Center http://www.nhc.noaa.gov

NOAA (National Oceanographic and Atmospheric Administration) (1930-1985). "Climatological Data Florida" National Climate Data Center, Asheville, North Carolina.

Noss, R.F., E.T. LaRoe III and J.M. Scott. 1995. Endangered Ecosystems of the United States: A Preliminary Assessment of Loss and Degradation. Biological Report 28. U.S. Department of the Interior, National Biological Service, Washington, DC.

Oba, G. 1990. Effects of wildfires on a semidesert riparian woodland along the Turkwel River, Kenya, and management implications for Turkana Pastroalists. Land Dedradation and Rehabilitation 2:247-259.

Ogawa, K. and A. Hagihara. 2003. Self-thinning and size variation in sugi (Cryptomeria japonica D. Don) plantation. Forest Ecology and Management 174:413-421. 
Olmsted, I and E.R.Alvarez-Buylla. 1995. Sustainable harvesting of tropical trees: demography and matrix models of two palm species in Mexico. Ecological Applications 5(2):484-500.

Orellana, R and N.N. Ayora. 1993. Population structure of two palm species in a community of sand dune scrub in the Yucatan Peninsula, Mexico. Principes 37(1): 26-34.

Overman, J.P.M., H.J.L. Witte, and J.G. Saldarriaga. 1994. Evaluation of regression models for above-ground biomass determination in Amazon rainforest. Journal of Tropical Ecology 10:207-218.

Pietro, C., S. Flasse, S. Tarantola, S. Jacquemound, J. Grégoire. 2001. Detecting vegetation leaf water content using reflectance in the optical domain. Remote Sensing of Environment 77: 22-33.

Pyne, S.J. 1989. The summer we let wild fire loose: How 'natural' were the fires of 1988? Natural History 8: 45-9.

Robertson, W.B. Jr. 1953. A Survey of the Effects of Fire in Everglades National Park. National Park Service. 169 pp.

Rocca, M. 1997. Site Characterization of Lower Keys Pine Rocklands. The Nature Conservancy. Unpublished document. Key West, Florida. 42pp.

Ross, M.S., T. L. Sharik, and D.Wm.Smith. 1982. Age-structure relationship of tree species in an Appalachian oak forest in southwest Virginia. Bulletin of the Torrey Botanical Club 109(3):287-298.

Ross, M.S., J.J. O'Brien and L.J. Flynn. 1992. Vegetation and Landscape Ecology of Central Big Pine Key. A report submitted to The Nature Conservancy. 62pp.

Ross, M.S. and P. Ruiz. 1996. A Study of the Distribution of Several South Florida Endemic Plants in the Florida Keys. A report to the U.S. Fish and Wildlife Service. $50 \mathrm{pp}$.

Ross, M., C.L. Coultas and Y.P. Hsieh. 2003. Soil-productivity relationships and organic matter turnover in dry tropical forests of the Florida Keys. Plant and Soil 253: $479-492$.

Rundel, P.W. 1981. Structural and chemical components of flammability, in Proceedings of the Conference on Fire Regimes and Ecosystems Properties, (eds H.A. Mooney, T.M. Bonnicksen, N.L. Christensen, J.E. Lotan and W.A. Reiners), United States Department Agriculture. Forest Service General Technical Report WO-86, 183-207pp. 
Sarukhán, J., D. Pinero and M. Martínez-Romos. 1985. Plant Demography: A

Community-level Interpretation. Studies on Plant Demography: A Festschrift for John L. Harper. Academic Press Inc., London, England.

Silva Matos, D.M., R.P. Freckleton, and A.R. Watkinson. 1999. The role of density dependence in the population dynamics of a tropical palm. Ecology 80(8):2635-2650.

Silvertown, J and D. Charlesworth. 2001. Introduction to Plant Population Biology. Blackwell Science. Oxford, England.

Snyder, J.R. 1984. The role of fire: Mutch ado about nothing? Oikos 43(3):404-405.

Snyder, J.R. 1986. The Impact of Wet Season and Dry Season Prescribed Fires on Miami Rock Ridge Pineland, Everglades National Park. Technical Report SFRC86/06. Everglades National Park, South Florida Research Center, Homestead, Florida, USA.

Snyder, J.R., A. Herndon and W.B. Robertson Jr.1990. South Florida Rockland. Pages 230-277 in R.L. Myers and J.J. Ewel, editors. Ecosystems of Florida. University of Central Florida Press, Orlando, Florida, USA.

Spalt, K.W. and W.E. Reifsnyder. 1962. Bark Characteristics and Fire Resistance: A Literature Survey. United States Department Agriculture. Forest Service Southern Forest Experimental Station Occasional Paper 193. New Orleans, LA. 19pp.

Spring, P.E., M.L. Brewer, J.R. Brown, and M.E. Fanning. 1974. Population ecology of loblolly pine Pinus taeda in an old field community Oikos 25:1-6.

Sprugel, D.G. 1983. Correcting for Bias in Log-Transformed Allometric Equations. Ecology 64(1):209-210.

Stephens, S. L. and M.A. Finney. 2002. Prescribed fire mortality of Sierra Nevada mixed conifer tree species: effects of crown damage and forest floor combustion. Forest Ecology and Management 162:261-271.

Tomlinson, P.B. 2001. The Biology of Trees Native to Tropical Florida. ( $2^{\text {nd }}$ ed.) Pages 340-355. Harvard Printing and Publishing Services, Allston, Massachusetts, USA.

United States Department of Agriculture. 1995. Natural Resources Conservation Service. 1995. Soil Survey of Monroe County, Keys Area, Florida.

United States Fish and Wildlife Service. 2000. Fire Management Plan National Key Deer Refuge. 2000. Unpublished document. 66pp. 
van Wilgen, B.W. 1982. Some effects of post-fire age on the above-ground plant biomass of fynbos (Macchia) vegetation in South Africa. Journal of Ecology 70(1):217-255.

van Wilgen, B.W., K.B. Higgins and D.U. Bellstedt. 2001. The role of vegetation structure and fuel chemistry in excluding fire from forest patches in the fire-prone fynbos shrublands of South Africa. Journal of Ecology 78(1):210-222.

Whelan, R.J. 1995. The Ecology of Fire. Cambridge University Press, Cambridge, U.K.

Whittaker, R.H. 1953. A consideration of climax theory: The climax as a population and pattern. Ecological Monographs 23(1):41-78

Winsberg, M.D. 2003. Florida Weather-second edition. University Press of Florida, Gainesville, Florida, USA.

Winter, G. and J.S. Fried. 2000. Homeowners perspectives on fire hazard, responsibility, and management strategies at the wildland-urban interface. Society and Natural Resources 13:33-49.

Wirth, C., E.-D. Schulze, W. Schulze, D. von Stünzner-Karbe, W. Ziegler, I.M. Miljukova, A. Sogatchev, A.B. Varlagin, M. Panvyorov, S. Grigoriev, W.

Kusnetzova, M. Siry, G. Hardes, R. Zimmermann, and N.N. Vygodskaya. 1999. Above-ground biomass and structure of pristine Siberian Scots pine forests as controlled by competition and fire. Oecologia 121:66-80.

Zona, S. 1997. The genera of Palmae (Arecaceae) in the Southeastern United States. Harvard Papers in Botany 11: 71-107.

Zona, S. and K. Maidman. 2000. Growth Rates of palms in Fairchild Tropical Garden. Palms 45(3): 151-154. 


\section{Appendices}

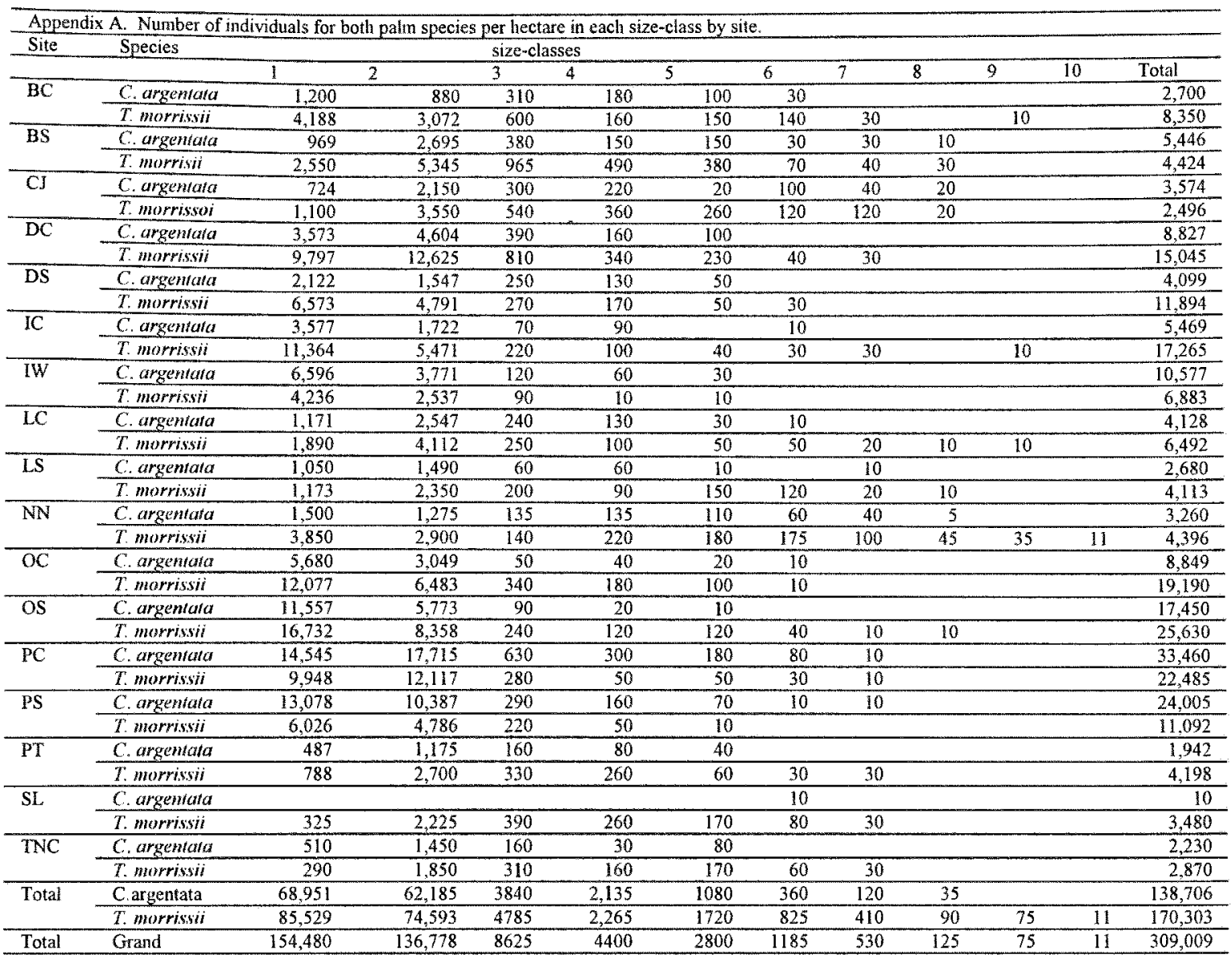




\begin{tabular}{|c|c|c|c|c|c|c|}
\hline \multicolumn{7}{|c|}{ Appendix B. Palm mortality by site } \\
\hline Site & Species & Reproductive & Dead & Live & Total & $\%$ Mortality \\
\hline \multirow[t]{4}{*}{$\mathrm{BC}$} & \multirow[t]{2}{*}{ C. argentata } & $\mathrm{N}$ & & 20 & 20 & 0 \\
\hline & & $\mathrm{Y}$ & & 20 & 20 & 0 \\
\hline & \multirow[t]{2}{*}{ T. morrisii } & $\mathrm{N}$ & & 20 & 20 & 0 \\
\hline & & $\mathrm{Y}$ & & 20 & 20 & 0 \\
\hline \multirow[t]{4}{*}{ BS } & \multirow[t]{2}{*}{ C. argentata } & $\mathrm{N}$ & 1 & 19 & 20 & 5 \\
\hline & & $\mathrm{Y}$ & 1 & 19 & 20 & 5 \\
\hline & \multirow[t]{2}{*}{ T. morrisii } & $\mathrm{N}$ & & 20 & 20 & 0 \\
\hline & & $\mathrm{Y}$ & 2 & 18 & 20 & 10 \\
\hline \multirow[t]{4}{*}{$\mathrm{BW}$} & \multirow[t]{2}{*}{ C. argentata } & $\mathrm{N}$ & 1 & 19 & 20 & 5 \\
\hline & & $\mathrm{Y}$ & 5 & 15 & 20 & 25 \\
\hline & \multirow[t]{2}{*}{ T. morrisii } & $\mathrm{N}$ & & 20 & 20 & 0 \\
\hline & & $\mathrm{Y}$ & & 20 & 20 & 0 \\
\hline \multirow[t]{4}{*}{ IC } & \multirow[t]{2}{*}{ C. argentata } & $\mathrm{N}$ & & 20 & 20 & 0 \\
\hline & & $\mathrm{Y}$ & & 20 & 20 & 0 \\
\hline & \multirow[t]{2}{*}{ T. morrisii } & $\mathrm{N}$ & & 20 & 20 & 0 \\
\hline & & $\mathrm{Y}$ & & 20 & 20 & 0 \\
\hline \multirow[t]{4}{*}{ IW } & \multirow[t]{2}{*}{ C. argentata } & $\mathrm{N}$ & 2 & 18 & 20 & 10 \\
\hline & & $Y$ & 5 & 15 & 20 & 25 \\
\hline & \multirow[t]{2}{*}{ T. morrisii } & $\mathrm{N}$ & 3 & 17 & 20 & 15 \\
\hline & & $\mathrm{Y}$ & 5 & 15 & 20 & 25 \\
\hline \multirow[t]{4}{*}{$\mathrm{LC}$} & \multirow[t]{2}{*}{ C. argentata } & $\mathrm{N}$ & & 20 & 20 & 0 \\
\hline & & $\mathrm{Y}$ & 1 & 19 & 20 & 5 \\
\hline & \multirow[t]{2}{*}{ T. morrisii } & $\mathrm{N}$ & & 21 & 21 & 0 \\
\hline & & $\mathrm{Y}$ & & 22 & 22 & 0 \\
\hline \multirow[t]{4}{*}{ LS } & \multirow[t]{2}{*}{ C. argentata } & $\mathrm{N}$ & 2 & 18 & 20 & 10 \\
\hline & & $\mathrm{Y}$ & 4 & 16 & 20 & 20 \\
\hline & \multirow[t]{2}{*}{ T. morrisii } & $\mathrm{N}$ & 1 & 19 & 20 & 5 \\
\hline & & $\mathrm{Y}$ & 1 & 19 & 20 & 5 \\
\hline \multirow[t]{4}{*}{$\mathrm{LW}$} & \multirow[t]{2}{*}{ C. argentata } & $\mathrm{N}$ & 2 & 20 & 22 & 9 \\
\hline & & $\mathrm{Y}$ & 4 & 19 & 23 & 17 \\
\hline & \multirow[t]{2}{*}{ T morrisii } & $\mathrm{N}$ & 2 & 20 & 22 & 9 \\
\hline & & $\mathrm{Y}$ & 2 & 20 & 22 & 9 \\
\hline Total & C. argentata & $\mathrm{N}$ & & 60 & 60 & 0 \\
\hline & & $\mathrm{Y}$ & 1 & 59 & 60 & 1.67 \\
\hline Control & T. morrisii & $\mathrm{N}$ & & 61 & 61 & 0 \\
\hline & & $\mathrm{Y}$ & & 62 & 62 & 0 \\
\hline Total & C. argentata & $\mathrm{N}$ & 8 & 94 & 102 & 7.8 \\
\hline & & $Y$ & 19 & 84 & 103 & 18.4 \\
\hline Burn & T. morrisii & $\mathrm{N}$ & 6 & 96 & 102 & 5.9 \\
\hline & & $Y$ & 10 & 92 & 102 & 9.8 \\
\hline
\end{tabular}


Appendix C. Comparison of criteria used to determine best regression model for the prediction of live $C$. argentata and T. morrisii aboveground, oven-dried, burnable biomass in the lower Florida Keys. $\mathrm{R}^{2}$ and absolute \% deviation were used to determine best regression model. $\mathrm{N}=15$ for both species.

Absolute percentage deviation $=\Sigma$ |predicted dry weight-observed dry weight $\mid * 100$ (Overman, 1994) Observed dry weight

$n$

\begin{tabular}{|c|c|c|c|c|c|}
\hline \multirow{2}{*}{\multicolumn{2}{|c|}{$\begin{array}{l}\text { Dependent Indepen } \\
\text { Coccothrinax argentata }\end{array}$}} & \multirow[t]{2}{*}{ p-value : } & SEE & $\mathrm{R}^{2}$ & Absolute $\%$ Deviation \\
\hline & & & & & \\
\hline Live wt $(g)$ & area & $<0.001$ & 172.26 & 0.715 & 74.7 \\
\hline Live wt $(g)$ & height & 0.043 & 274.01 & 0.28 & 160.0 \\
\hline Live wt $(\mathrm{g})$ & apical height & 0.113 & 292.05 & 0.182 & 238.8 \\
\hline Live wt (g) & total Heaves & $<0.001$ & 110.27 & 0.883 & 131.3 \\
\hline Live wt $(\mathrm{g})$ & area theight & $<0.001$ & 175.59 & 0.727 & 55.3 \\
\hline Live wt $(\mathrm{g})$ & areatapical height & $<0.001$ & 175.48 & 0.727 & 62.6 \\
\hline Live wt $(\mathrm{g})$ & area+ total lvs & $<0.001$ & 90.58 & 0.927 & 124.6 \\
\hline Live wt $(\mathrm{g})$ & height+ total \# lvs & $<0.001$ & 109.31 & 0.894 & 141.9 \\
\hline Live wt (g) & apical height+total \# Ivs & $<0.001$ & 107.43 & 0.898 & 140.0 \\
\hline $\ln ($ Live $w t)(g)$ & $\ln$ (area) & $<0.001$ & 0.50 & 0.843 & 46.9 \\
\hline In (Live wt) (g) & In (height) & 0.001 & 0.82 & 0.584 & 111.6 \\
\hline In (Live wt) (g) & In (apical height) & 0.002 & 0.87 & 0.528 & 134.8 \\
\hline $\ln ($ Live $w t)(g)$ & $\ln$ (\# total leaves) & $<0.001$ & 0.48 & 0.854 & 42.6 \\
\hline $\ln ($ Live $w \mathrm{t})(\mathrm{g})$ & In (area) $+\ln$ (height) & $<0.001$ & 0.52 & 0.843 & 47.4 \\
\hline $\ln$ (Live wt) (g) & $\ln ($ area $)+\ln ($ apical height) & $<0.001$ & 0.52 & 0.846 & 46.1 \\
\hline $\ln ($ Live $w t)(g)$ & $\ln$ (area) $+\ln$ (total \#lvs) & $<0.001$ & 0.22 & 0.972 & 14.6 \\
\hline $\ln ($ Live wt) $(\mathrm{g})$ & In (height)+ $\ln$ (total \#lvs) & $<0.001$ & 0.35 & 0.927 & 29.3 \\
\hline ln (Live wt) (g) & In (apical height) $+\ln$ (total\#lvs) & $<0.001$ & 0.32 & 0.94 & 26.2 \\
\hline \multicolumn{6}{|c|}{ Thrinax morrisii } \\
\hline Live wt $(\mathrm{g})$ & area & $<0.001$ & 602.60 & 0.874 & 266.2 \\
\hline Live wt $(g)$ & height & 0.005 & 1246.67 & 0.46 & 699.3 \\
\hline Live wt $(\mathrm{g})$ & apical height & 0.039 & 1432.02 & 0.287 & 1296.5 \\
\hline Live wt (g) & total \#leaves & $<0.001$ & 625.63 & 0.864 & 231.9 \\
\hline Live wt $(\mathrm{g})$ & areatheight & $<0.001$ & 520.06 & 0.913 & 46.1 \\
\hline Live wt $(g)$ & area+apical height & $<0.001$ & 524.14 & 0.912 & 55.2 \\
\hline Live wt $(\mathrm{g})$ & area+ total \# lvs & $<0.001$ & 391.18 & 0.951 & 143.0 \\
\hline Live wt $(\mathrm{g})$ & height+ total \# lvs & $<0.001$ & 589.30 & 0.889 & 268.9 \\
\hline Live wt (g) & apical height+total \# lvs & $<0.001$ & 567.79 & 0.897 & 272.9 \\
\hline $\ln ($ Live wt) (g) & $\ln$ (area) & $<0.001$ & 0.37 & 0.967 & 30.1 \\
\hline In (Live wt) (g) & $\ln$ (height) & $<0.001$ & 0.84 & 0.829 & 116.9 \\
\hline In (Live wt) (g) & In (apical height) & $<0.001$ & 0.87 & 0.814 & 121.3 \\
\hline In (Live wt) (g) & In (\# total leaves) & $<0.001$ & 0.59 & 0.916 & 63.4 \\
\hline In (Live wt) (g) & $\ln$ (area) $+\ln ($ height) & $<0.001$ & 0.27 & 0.983 & 21.1 \\
\hline In (Live wt) (g) & $\ln$ (area) $+\ln$ (apical height) & $<0.001$ & 0.27 & 0.984 & 36.5 \\
\hline In (Live wt) (g) & In (area)+ In (total \#lvs) & $<0.001$ & 0.33 & 0.975 & 26.3 \\
\hline In (Live wt) (g) & In (height) + In (total Hlvs) & $<0.001$ & 0.59 & 0.92 & 62.5 \\
\hline In (Live wt) (g) & In (apical height) $+\ln$ (total $\#$ lvs) & $<0.001$ & 0.59 & 0.923 & 60.1 \\
\hline
\end{tabular}


Appendix D. Comparison of criteria used to determine best regression model for the prediction of dead attached $C$. argentata and T. morrisii aboveground, oven-dried, burnable biomass in the lower Florida Keys. $\mathrm{R}^{2}$ and absolute \% deviation were used to determine best regression model. $\mathrm{N}=15$ for both species.

Absolute percentage deviation $=\Sigma$ |predicted dry weight-observed dry weight $\mid{ }^{*} 100$ (Overman, 1994) Observed dry weight

\begin{tabular}{|c|c|c|c|c|c|}
\hline \multirow{2}{*}{\multicolumn{2}{|c|}{$\begin{array}{l}\text { Dependent } \quad \text { Independ } \\
\text { Coccothrinax argentata }\end{array}$}} & \multirow[t]{2}{*}{ p-value : } & SEE & $2^{2}$ & Absolute $\%$ Deviation \\
\hline & gentata & & & & \\
\hline Dead wt $(\mathrm{g})$ & area & 0.02 & 286.20 & 0.349 & 114.1 \\
\hline Dead wt $(g)$ & height & 0.441 & 346.46 & 0.046 & 215.4 \\
\hline Dead wt $(g)$ & apical height & 0.564 & 350.08 & 0.026 & 247.3 \\
\hline Dead wt $(g)$ & total \#leaves & 0.003 & 249.90 & 0.504 & 176.5 \\
\hline Dead wt $(\mathrm{g})$ & area+height & 0.032 & 277.08 & 0.437 & 86.8 \\
\hline Dead wt $(g)$ & areatapical height & 0.042 & 283.50 & 0.411 & 86.6 \\
\hline Dead wt $(\mathrm{g})$ & area+ total \# lvs & 0 & 184.43 & 0.751 & 114.1 \\
\hline Dead wt $(g)$ & height+ total \# Ivs & 0.002 & 220.66 & 0.643 & 70.5 \\
\hline Dead wt $(g)$ & apical height+total \# lvs & 0.003 & 226.85 & 0.623 & 65.7 \\
\hline $\ln ($ Dead wt) $(\mathrm{g})$ & $\ln ($ area) & 0 & 0.69 & 0.688 & 73.3 \\
\hline $\ln ($ Dead wt $)(\mathrm{g})$ & ln (height) & 0.021 & 1.00 & 0.345 & 158.4 \\
\hline $\ln ($ Dead $w t)(g)$ & In (apical height) & 0.016 & 0.98 & 0.368 & 158.0 \\
\hline In (Dead wt) $(\mathrm{g})$ & In (\# total leaves) & 0.019 & 0.99 & 0.355 & 210.2 \\
\hline $\ln ($ Dead wt) $(g)$ & $\ln ($ area $)+\ln ($ height $)$ & 0 & 0.67 & 0.729 & 69.3 \\
\hline In (Dead wt) $(g)$ & $\ln ($ area $)+\ln ($ apical height) & 0.001 & 0.69 & 0.708 & 72.1 \\
\hline In (Dead wt) $(g)$ & $\ln ($ area $)+\ln ($ total \#lvs) & 0 & 0.40 & 0.903 & 32.0 \\
\hline $\ln ($ Dead wt) $(g)$ & $\ln$ (height) $+\ln$ (total Hlvs) & 0 & 0.44 & 0.879 & 36.5 \\
\hline $\ln ($ Dead wt) $(g)$ & In (apical height) $+\ln ($ total\#lvs) & 0 & 0.45 & 0.878 & 38.1 \\
\hline \multicolumn{6}{|l|}{ Thrinax morrisii } \\
\hline Dead wt $(g)$ & area & 0.001 & 2056.46 & 0.605 & 81.9 \\
\hline Dead wt $(\mathrm{g})$ & height & 0.081 & 2898.10 & 0.216 & 2145.7 \\
\hline Dead wt $(\mathrm{g})$ & apical height & 0.166 & 3031.60 & 0.142 & 3546.7 \\
\hline Dead wt $(g)$ & total Heaves & 0 & 1171.67 & 0.872 & 278.4 \\
\hline Dead wt $(g)$ & area+height & 0.004 & 2134.60 & 0.607 & 301.3 \\
\hline Dead wt $(\mathrm{g})$ & area + apical height & 0.003 & 2119.43 & 0.613 & 407.6 \\
\hline Dead wt $(\mathrm{g})$ & area+ total \# lvs & 0 & 967.55 & 0.919 & 833.0 \\
\hline Dead wt $(\mathrm{g})$ & height+ total \# Ivs & 0 & 1091.09 & 0.897 & 850.3 \\
\hline Dead wt $(\mathrm{g})$ & apical height+total \# lvs & 0 & 1100.84 & 0.896 & 593.1 \\
\hline $\ln ($ Dead wt $)(g)$ & $\ln$ (area) & 0 & 0.58 & 0.941 & 60.8 \\
\hline In (Dead wt) $(g)$ & ln (height) & 0 & 1.10 & 0.785 & 226.5 \\
\hline $\ln ($ Dead wt $)(g)$ & In (apical height) & 0 & 1.08 & 0.793 & 213.9 \\
\hline In $($ Dead wt) $(g)$ & $\ln (\#$ total leaves) & 0 & 1.12 & 0.775 & 241.9 \\
\hline $\ln ($ Dead wt) $(g)$ & $\ln ($ area $)+\ln$ (height) & 0 & 0.54 & 0.951 & 51.4 \\
\hline $\ln ($ Dead wt) $(\mathrm{g})$ & $\ln ($ area $)+\ln ($ apical height) & 0 & 0.51 & 0.957 & 48.0 \\
\hline In (Dead wt) $(\mathrm{g})$ & $\ln ($ area $)+\ln ($ total \#lvs) & 0 & 0.46 & 0.965 & 38.2 \\
\hline In (Dead wt) $(g)$ & $\ln ($ height $)+\ln ($ total \#lvs) & 0 & 0.59 & 0.944 & 55.6 \\
\hline $\ln ($ Dead wt) $(\mathrm{g})$ & In (apical height) $+\ln ($ total $\#$ lvs) & 0 & 0.58 & 0.945 & 56.7 \\
\hline
\end{tabular}




\begin{tabular}{|c|c|c|c|c|}
\hline Site & Biomass & C. argentata $(\mathrm{kg} / \mathrm{ha})$ & T. morrisii (kg/ha) & Total $(\mathrm{kg} / \mathrm{ha})$ \\
\hline \multirow[t]{3}{*}{$\mathrm{BC}$} & Live & 204 & 3,405 & 3,608 \\
\hline & Dead & 279 & 4,655 & 4,933 \\
\hline & Total & 517 & 8,155 & 8,673 \\
\hline \multirow[t]{3}{*}{ BS } & Live & 420 & 760 & 1,181 \\
\hline & Dead & 127 & 317 & 444 \\
\hline & Total & 565 & 1,176 & 1,741 \\
\hline \multirow[t]{3}{*}{$\mathrm{CJ}$} & Live & 345 & 2,784 & 3,129 \\
\hline & Dead & 414 & 4,051 & 4,465 \\
\hline & Total & 792 & 6,859 & 7,651 \\
\hline \multirow[t]{3}{*}{$\mathrm{DC}$} & Live & 766 & 4,424 & 5,190 \\
\hline & Dead & 1,179 & 5,872 & 7,051 \\
\hline & Total & 2,097 & 10,455 & 12,552 \\
\hline \multirow[t]{3}{*}{ DS } & Live & 232 & 1,966 & 2,198 \\
\hline & Dead & 220 & 1,510 & 1,731 \\
\hline & Total & 461 & 3,533 & 3,993 \\
\hline \multirow[t]{3}{*}{ IC } & Live & 188 & 1,802 & 1,990 \\
\hline & Dead & 244 & 2,531 & 2,775 \\
\hline & Total & 449 & 4,551 & 5,000 \\
\hline \multirow[t]{3}{*}{ IW } & Live & 292 & 274 & 565 \\
\hline & Dead & 180 & 109 & 289 \\
\hline & Total & 468 & 401 & 868 \\
\hline \multirow[t]{3}{*}{ LC } & Live & 261 & 2,326 & 2,588 \\
\hline & Dead & 331 & 2,736 & 3,067 \\
\hline & Total & 620 & 5,119 & 5,740 \\
\hline \multirow[t]{3}{*}{ LS } & Live & 108 & 565 & 673 \\
\hline & Dead & 32 & 365 & 397 \\
\hline & Total & 140 & 978 & 1,118 \\
\hline \multirow[t]{3}{*}{$\mathrm{NN}$} & Live & 576 & 2,366 & 2,943 \\
\hline & Dead & 300 & 2,464 & 2,764 \\
\hline & Total & 869 & 4,847 & 5,716 \\
\hline \multirow[t]{3}{*}{$\mathrm{OC}$} & Live & 319 & 2,847 & 3,166 \\
\hline & Dead & 549 & 3,961 & 4,509 \\
\hline & Total & 934 & 6,989 & 7,923 \\
\hline \multirow[t]{3}{*}{ OS } & Live & 440 & 2,486 & 2,926 \\
\hline & Dead & 639 & 2,439 & 3,078 \\
\hline & Total & 1,150 & 5,001 & 6,151 \\
\hline \multirow[t]{3}{*}{$\mathrm{PC}$} & Live & 2,916 & 5,146 & 8,061 \\
\hline & Dead & 4,560 & 6,041 & 10,601 \\
\hline & Total & 8,053 & 11,450 & 19,503 \\
\hline \multirow[t]{3}{*}{ PS } & Live & 1,238 & 1,376 & 2,614 \\
\hline & Dead & 2,175 & 1,186 & 3,362 \\
\hline & Total & 3,687 & 2,620 & 6,307 \\
\hline \multirow[t]{3}{*}{ PT } & Live & 134 & 2,595 & 2,729 \\
\hline & Dead & 113 & 3,308 & 3,421 \\
\hline & Total & 247 & 5,970 & 6,218 \\
\hline \multirow[t]{3}{*}{ SL. } & Live & 5 & 1,787 & 1,792 \\
\hline & Dead & 0 & 2,386 & 2,386 \\
\hline & Total & 6 & 4,214 & 4,220 \\
\hline \multirow[t]{3}{*}{ TNC } & Live & 162 & 1,733 & 1,895 \\
\hline & Dead & 175 & 2,146 & 2,320 \\
\hline & Total & 348 & 3,939 & 4,287 \\
\hline
\end{tabular}




\begin{tabular}{lrrr}
\hline \multicolumn{4}{c}{ Appendix F. Total C. argentata and T. morrisii litter by site } \\
\hline Site & C. argentata $(\mathrm{kg} / \mathrm{ha})$ & T. morrisii $(\mathrm{kg} / \mathrm{ha})$ & Total (kg/ha) \\
\hline BC & 169 & 1,451 & 1,620 \\
BS & 119 & 89 & 208 \\
DC & 299 & 1,887 & 2,186 \\
DS & 98 & 153 & 251 \\
IC & 73 & 470 & 543 \\
IW & 34 & 30 & 64 \\
LC & 161 & 1,299 & 1,460 \\
LS & 22 & 133 & 155 \\
NN & 357 & 1,379 & 1,736 \\
OC & 67 & 595 & 662 \\
OS & 73 & 196 & 269 \\
PC & 1,108 & 577 & 1,685 \\
PS & 174 & 38 & 212 \\
\hline
\end{tabular}

